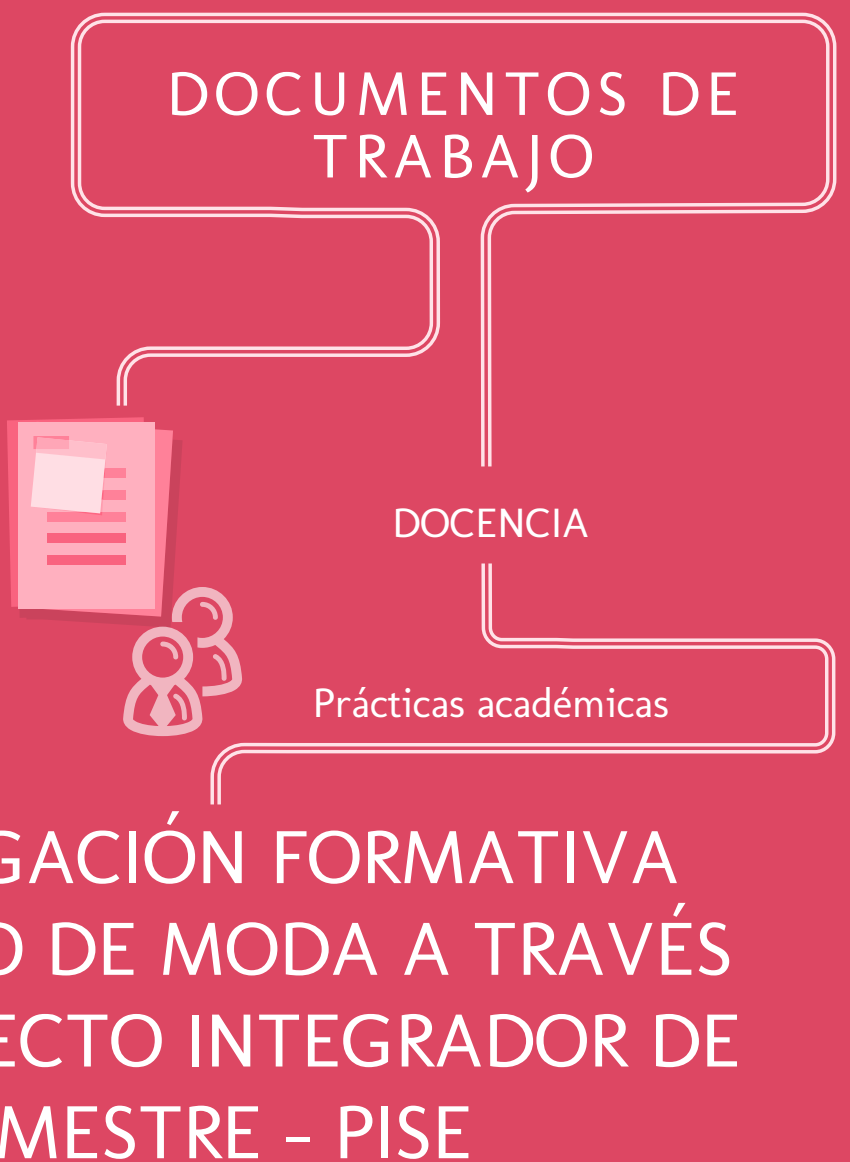

Olga lucía Zipa Patiño, Lida Eugenia lora Gómez, Cielo Andrea lizarazo linares, Mary Evelin Ruíz, Christian Camilo Caicedo Moreno
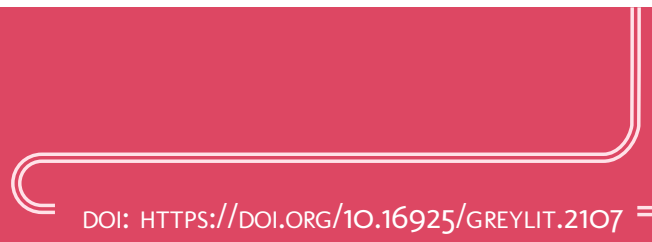
INTELIGENCIA DE LA MANO

DE LA ACADEMIA

(c) Fundación Universitaria del Área Andina

Bogotá, abril de 2018

(c) Jaison Eduardo Rodríguez Cifuentes,

Paula Andrea López Paloma

Dol: https://doi.org/10.16925/greylit.2107

Fundación Universitaria del Área Andina

Calle 70 No. 12-55, Bogotá, Colombia

Tel: +57 (1) 7424218 Ext. 1231

Correo electrónico: publicaciones@areandina.edu.co

Dirección editorial: Eduardo Mora Bejarano Coordinación editorial: Camilo Andrés Cuéllar Mejía

Diseño: Ivonne Carolina Cardozo Pachón

Diagramación: William Bernardo Ruiz Joya

Corrección De Estilo: Jorge Armando Duran Sanchez

BANDERA INSTITUCIONAL BOGOTÁ

Pablo Oliveros Marmolejo †

Gustavo Eastman Vélez

Miembros Fundadores

Diego Molano Vega

Presidente del Consejo Superior y Asamblea

General

José Leonardo Valencia Molano

Rector Nacional

Representante Legal

Martha Patricia Castellanos Saavedra

Vicerrectora Nacional Académica

Tatiana Guzmán Granados

Vicerrectora Nacional Administrativa y Financiera

Javier Ortiz Muñoz

Secretario General

Eduardo Mora Bejarano

Director Nacional de Investigaciones

Camilo Andrés Cuéllar Mejía

Coordinador Nacional de Publicaciones

Jorge Hernan Rosero Pulido

Decano Facultad de Diseño Gráfico

Flor Viviana Nariño Bernal

Directora Programa de Diseño Gráfico 
Las series de documentos de trabajo de la Fundación Universitaria del Área Andina se crearon para divulgar procesos académicos e investigativos en curso, pero que no implican un resultado final. Se plantean como una línea rápida de publicación que permite reportar avances de conocimiento generados por la comunidad de la institución. 


\section{INVESTIGACIÓN FORMATIVA EN DISEÑO DE MODA A TRAVÉS DEL PROYECTO INTEGRADOR DE SEMESTRE - PISE}

Asignaturas de diseño

Olga Lucia Zipa Patiño: Diseñadora de modas y textiles, especialista en Didáctica del Arte, magíster en Gestión de Proyectos de Innovación y Producto. Artista gráfico. Cuenta con 20 años en el ejercicio pedagógico, ha tenido la oportunidad de orientar proyectos de investigación desde el co-diseño aplicado a los requerimientos en entornos de la salud y proyectos enfocados en el reconocimiento de patrimonios culturales. Docente universitaria en las áreas de diseño, expresión e ilustración y semiótica.

Lida Eugenia Lora Gómez: Diseñadora textil y diseñadora de modas, especialista en Didáctica del Arte, candidata a magíster en Educación y Procesos Cognitivos. Cuenta con más de 25 años de experiencia en el sector textil e investigativo desde la academia. De esta manera se aporta en el aula de clase al desarrollo creativo de los estudiantes desde la experimentación y la intervención con diferentes fibras, hilos, telas y acabados textiles.

Cielo Andrea Lizarazo Linares: Diseñadora industrial con profundización en el área de gestión, especialista en Diseño y Desarrollo de Producto enfocado a marroquinería, calzado y cuero. Experiencia en generación y desarrollo de marca. Actual main leader de la empresa Santo Cielo Diseño S.A.S.

Con sus marcas de calzado Snakers y Santo Cielo. Beneficiaria de capital semilla del Fondo Emprender. Docente universitaria en las carreras de Diseño industrial y de moda
Olga Lucía Zipa Patiño, Lida Eugenia Lora Gómez, Cielo Andrea Lizarazo Linares, Mary Evelin Ruíz, Christian Camilo Caicedo Moreno en diferentes universidades, con experiencia de 6 años. También es consultora de diseño para medianas y pequeñas empresas del sector de calzado en Bogotá, para la Cámara de Comercio, ACICAM y CEINNOVA.

Carolina Sepúlveda García: Diseñadora industrial, especialista en Diseño Estratégico e Innovación. Con amplia experiencia en el sector público y privado en temas de formación, diseño y ejecución de proyectos para el sistema moda, asociados con la conceptualización, producción y creación de estrategias de comunicación y comercialización, centrado en el análisis y propuestas para usuarios y contextos reales.

Yanira Alejandra Alfonso Fandiño: Diseñadora gráfica y de modas, especialista en Didáctica del Arte, maestrante en Diseño con énfasis en investigación. Ha realizado cursos de profundización en metodologías de enseñanza, además de técnicas artísticas de ilustración en instituciones internacionales, con miras a la implementación en el quehacer diario profesional y académico. Con más de 12 años de experiencia en creaciones gráficas, orientadas en los últimos 6 años a la expresión en diseño de modas. Docente universitaria en las carreras de Diseño Gráfico, Animación y de Moda en diferentes universidades.

Swen Ramírez Rasmussen: Diseñador de modas y textiles, especialista en Didáctica del Arte, con estudios de profundización en Diseño de Joyería. Aspirante a magíster en Educación y Entornos Virtuales de Aprendizaje. Cuenta con más de 18 años de experiencia en el campo investigativo y la docencia en las áreas de diseño para artes escénicas, diseño de Alta Moda y maquillaje de fantasía-caracterización. 
Asignaturas de arquitectura del vestido

Mary Evelin Ruíz: Diseñadora de modas y textiles, especialista en Pedagogía para la Docencia Universitaria. Cuenta con más de 25 años de experiencia en el sector industrial y académico de la moda, desde la generación de módulos de producción e ingeniería para plantas de producción. Desde el aula de clase se fortalecen procesos encaminados a la fidelización del proceso textil y de confección aplicados al sector real.

Christian Camilo Caicedo Moreno: Diseñador de modas y textiles, especialista en Didáctica del Arte, estudios de profundización en Visual Merchandising y magíster en Dirección Estratégica en Marketing. Cuenta con más de diez años de experiencia en el campo investigativo y la docencia desde el área del patronaje y confección especializado en universo del vestuario jeanswear.

Gina Elizabeth Ortiz García: Diseñadora de modas con especialización en Gestión de la Productividad y la Calidad, experiencia en formación para el sector productivo de la confección industrial, en áreas de patronaje, trazo, corte y confección a nivel industrial. Además de experiencia en diseño de estructuras curriculares, construcción, aplicación de proyectos y elaboración del material pedagógico del área de confección, orientados al desarrollo de competencias laborales. Diseñadora, patronista y supervisora para empresas y microempresas del sector productivo de la confección.

\section{Cómo citar este documento:}

Jaison Eduardo Rodríguez Cifuentes, Paula Andrea López Paloma. Inteligencia de la mano de la academia. Enero 2018. Pág. 5. Dol: https://doi.org/10.16925/greylit.2107

\section{Resumen}

El programa de Diseño de modas de la Fundación Universitaria del Área Andina, en sus veinticinco años, ha desarrollado diferentes estrategias pedagógicas que le han permitido, por su experiencia, ser un referente en la comunidad académica y el sector diseño, textil y confección. A través del Proyecto Integrador de Semestre - PISE, y desde el trabajo sincronizado de las cátedras de Diseño, junto con las de Arquitecturas del vestido y las de llustración de moda, principalmente, se han obtenido resultados significativos que se quieren dar a conocer a toda la comunidad académica.

Teniendo como soporte las líneas de investigación de la facultad, las cuales son patrimonio y cultura, diseño e innovación, comunicación interactiva y pedagogía en diseño, se propone un tema general por parte de la dirección y equipo docente del programa, el cual se divide en subtemas de investigación de acuerdo con los universos del vestuario y al semestre que corresponda. De acuerdo con los requerimientos del portafolio y la exploración de cada estudiante, se conceptualiza la colección y se elige un atuendo para ser elaborado con el apoyo de los conocimientos adquiridos en las cátedras de patronaje y confección Arquitecturas.

El atuendo final es presentado ante Jurados externos, docentes, estudiantes e invitados y se entrega junto con el portafolio final y un artículo de investigación-creación como soporte del proceso articulado durante el semestre. Para el 2019-1 se desarrollaron los conceptos dentro de la temática, Conectar saberes, arte y creatividad, representados en siluetas retro con detalles en superficies maximizados y las mejores propuestas se presentaron en la pasarela de Colombiamoda 2019.

Palabras clave Creación, experimentación textil, formación en diseño, investigación, moda, tendencias. 


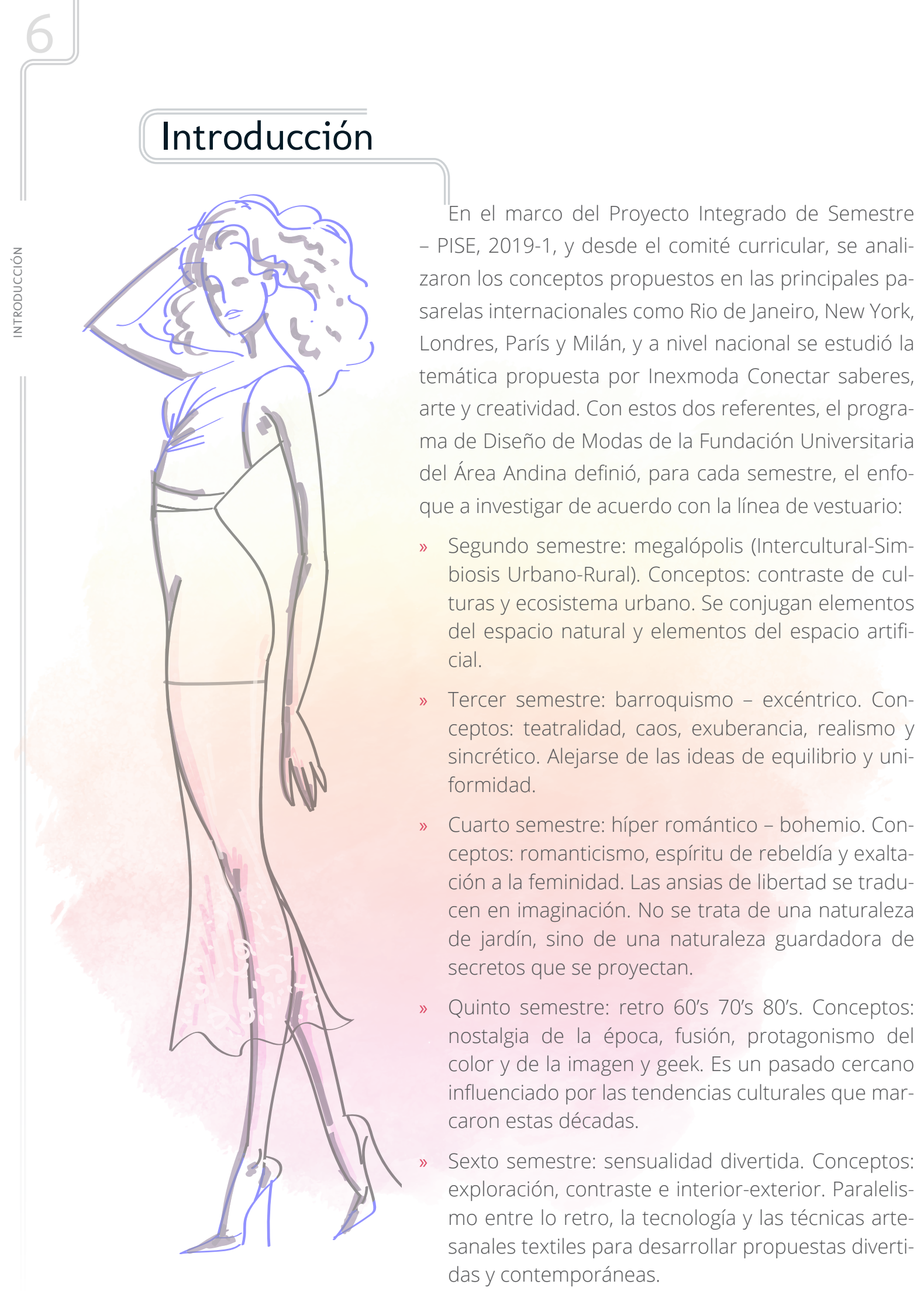


Séptimo semestre: trascender - punto de encuentro. Lectura del entorno, autoconocimiento y metáforas. Conceptos: conocimiento objetivo de la realidad, partiendo de la experiencia y la dimensión de la vida humana.

A partir de estas temáticas, los estudiantes realizaron un artículo de investigación-creación donde contaron su experiencia y los resultados obtenidos. Los mejores artículos, por semestre, se presentaron en esta Guía de curso 2019-1.

Las propuestas de colección, accesorios y portafolio que se desarrollaron durante el semestre, para la semana 15, ya se habían materializado. Esto permitió, a los docentes que participaron en el proceso, realizar una preentrega con sus estudiantes y recibir las correcciones necesarias con el aval para presentarse con más seguridad en la semana 16 ante un jurado externo.

De este proceso, y de la evaluación final de los jurados externos, se seleccionaron las mejores propuestas de indumentaria que se destacaron por su investigación, impacto visual y acabados, para participar en uno de los eventos de moda más importantes del país: Colombiamoda 2019.

La pasarela Académica Areandina Colombiamoda 2019, propuso un concepto retro con detalles maximizados, inspirado en las megalópolis, el barroquismo excéntrico, lo híper romántico, la sensualidad divertida y el trascender, como creativos, hasta encontrarnos con nuestro propio ser.

La puesta en escena se llamó maxi-retro en línea femenina y masculina, en universos de vestuario casual, formal, beachwear, gala y novias; propuesta de una escuela de alta calidad.

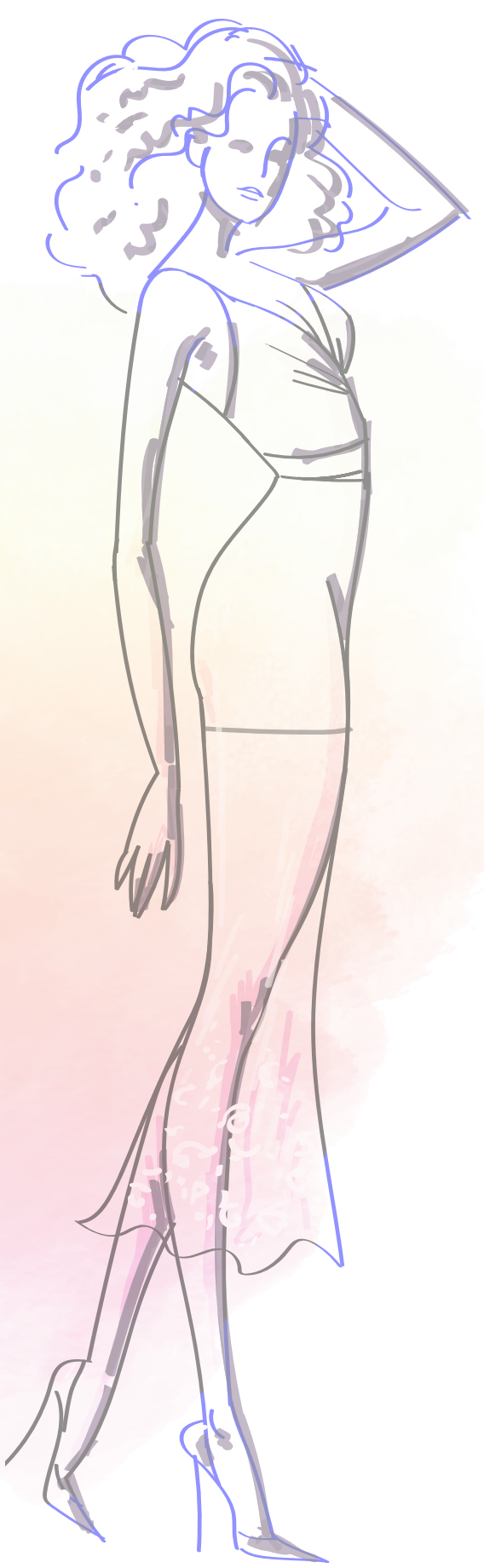




\section{Unidad 1.}

Tema de investigación 2019-1: conectar saberes, arte y creatividad Semestres II y III

Línea de investigación: patrimonio y cultura

Con el desarrollo de esta línea se busca contribuir al rescate, promoción y difusión de las prácticas vivas que constituyen el patrimonio material e inmaterial colombiano; desde lo ancestral, rural y urbano (tradiciones, oralidades, prácticas, imaginarios, filosofía, representaciones, conocimientos, técnicas, usos, saberes, artes, etc.); con el fin de generar fundamentos que aporten a la generación de soluciones a problemas actuales desde la cultura del diseño.

\section{Núcleos problémicos}

» Memoria cultural

» Saberes e identidad cultural

» Significados culturales

Segundo semestre: diseño experimental

Núcleo problémico Saberes e identidad cultural.

Subtema de investigación La megalópolis.

Palabras clave

Intercultural-simbiosis urbano-rural. 


\section{Objetivo}

Desarrollar competencias investigativas en los estudiantes de segundo semestre de Diseño de Modas de la Fundación Universitaria del Área Andina, sede Bogotá; investigando sobre las grandes ciudades en el mundo que han permitido el intercambio y contraste entre culturas; se conjugan elementos del espacio natural y elementos del espacio artificial para generar un ecosistema urbano.

Experimentando con los fundamentos del diseño, el modelado sobre maniquí y la producción industrial de colecciones; con el fin de diseñar una colección en línea femenina para el universo de vestuario casual.

\section{Entregables}

» Semana 8

» Artículo de investigación

» Moodboard de concepto

» Bitácora de diseño

» Colección de diez diseños de línea femenina del universo de vestuario casual

$\gg$ Semana 16

» Bitácora de diseño, desarrollo de colección y diseño de calzado.

» Colección de diez diseños, femenino casual y propuesta de color.

» Un indumento femenino casual experimental y calzado, t.40, en cuero o sintético, mate.

\section{Bases textiles}

Fibras naturales: algodones (driles, gabardinas, chambray, popelinas) y linos.

Indumentos seleccionados para la gira de medios Colombiamoda 2019, segundo semestre

Ver figura 1, figura 2, figura 3 y figura 4. 


\section{FIGURA 1}

EXPERIMENTAL FEMENINO. VALERIA CORSO CRUZ.
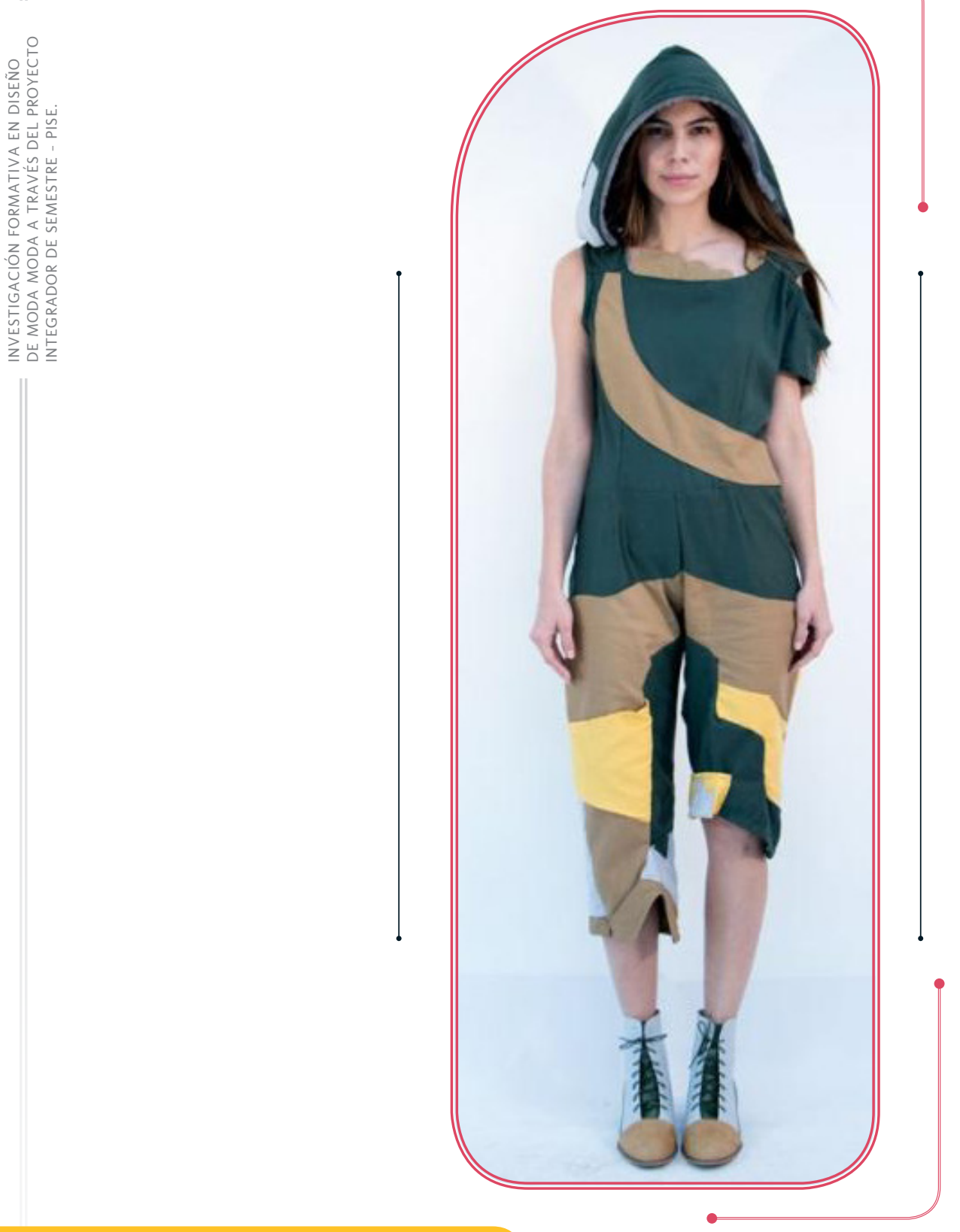

Fuente: Auditorio Fundación Universitaria del Área Andina, sede Bogotá.

Programa de Diseño de Modas León, 2019. 


\section{FIGURA 2}

EXPERIMENTAL FEMENINO. MARÍA PAULA VEGA BUSTAMANTE.

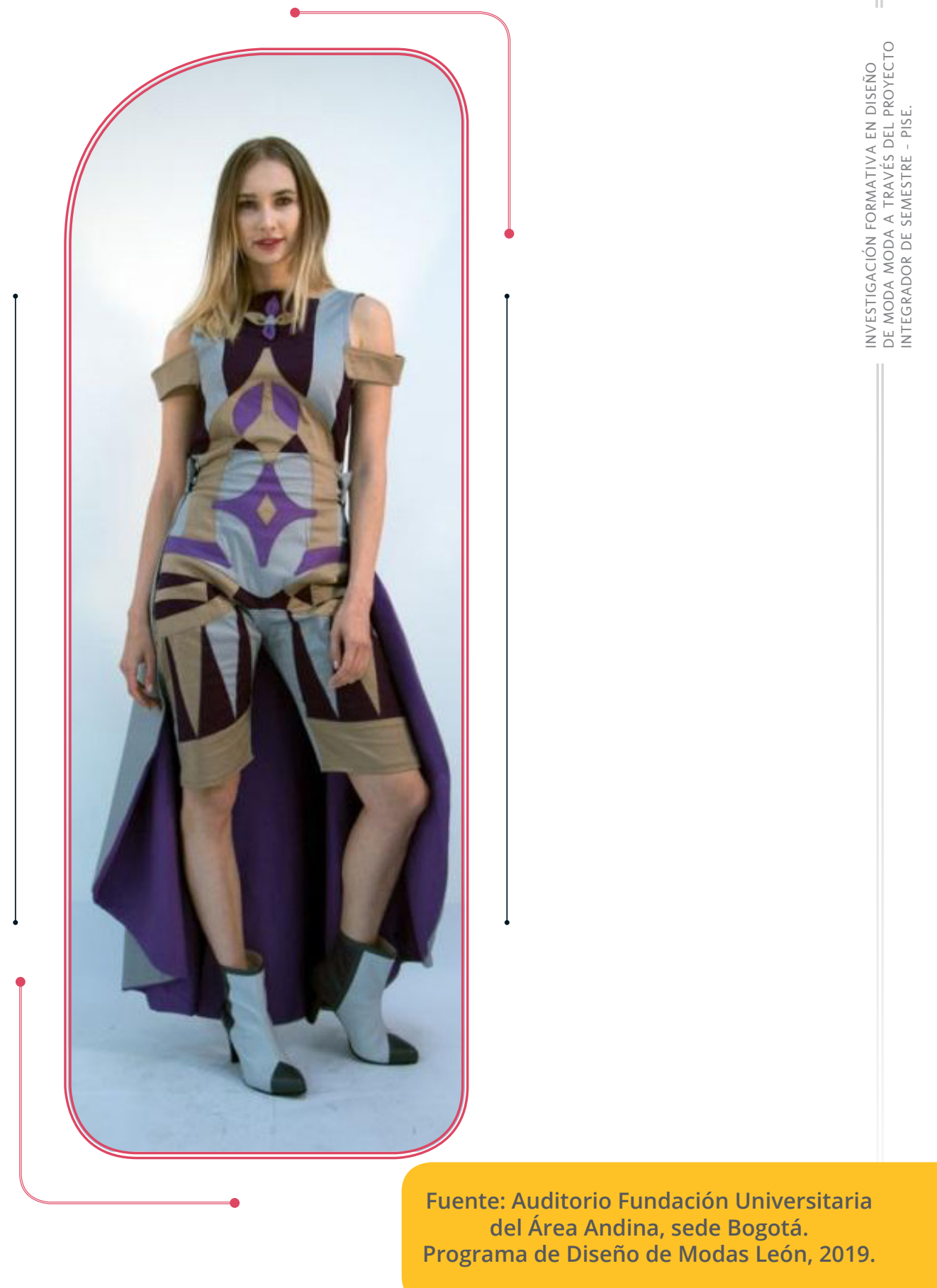




\section{FIGURA 3}

EXPERIMENTAL FEMENINO. GILLIAN ISLENDY BLANCO LÓPEZ.
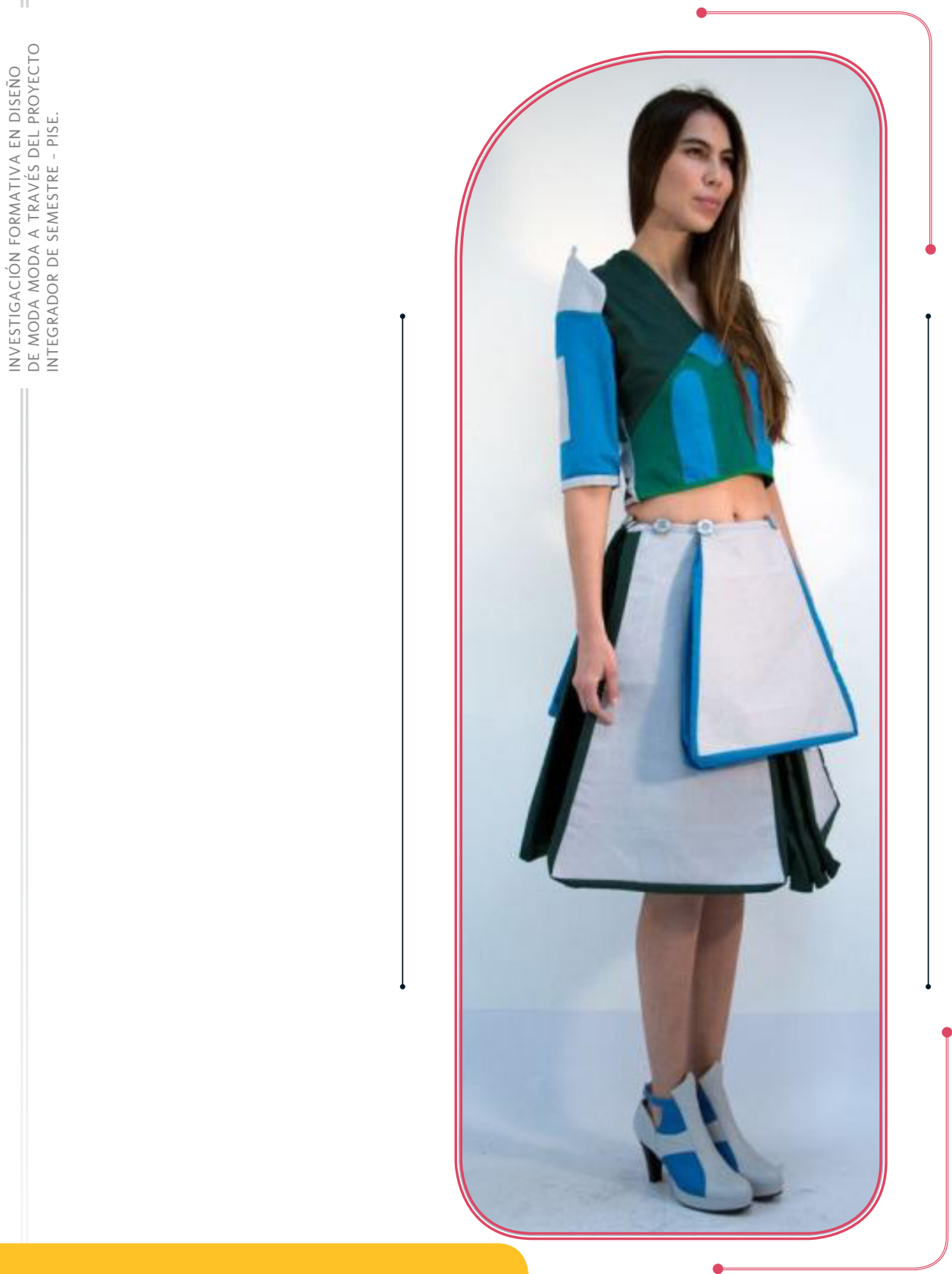

Fuente: Auditorio Fundación Universitaria del Área Andina, sede Bogotá.

Programa de Diseño de Modas León, 2019. 


\section{FIGURA 4}

EXPERIMENTAL FEMENINO. DIANA SOFÍA CAÑÓN GARZÓN.

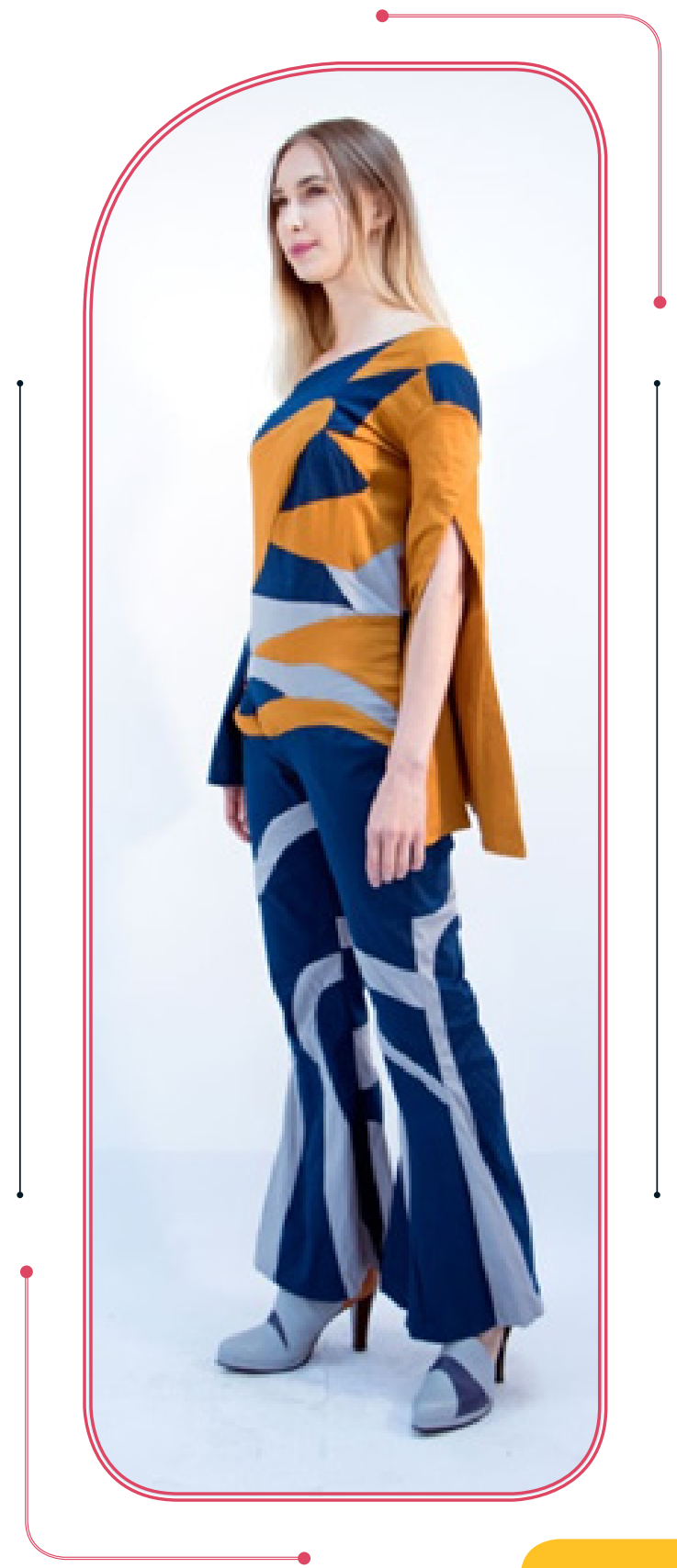
del Área Andina, sede Bogotá.

Programa de Diseño de Modas León, 2019. 


\section{Artículo resultado final: Santuario de las Lajas. Un milagro al borde de un abismo. María Paula Vega Bustamante}

\section{Resumen}

El Proyecto Integrador de segundo semestre tiene como tópico la Megalópolis, un término que, en esta cuestión es utilizado para hacer referencia a la simbiosis entre las áreas urbanas y la naturaleza. Esta colección representa, e interpreta, lo que es considerado un milagro arquitectónico al borde de un abismo, e incluso, una de las iglesias más bellas del mundo.

\section{Palabras clave}

Cultura, interpretación simbólica, Ipiales, moda, Nariño, Santuario de Las Lajas.

\section{Introducción}

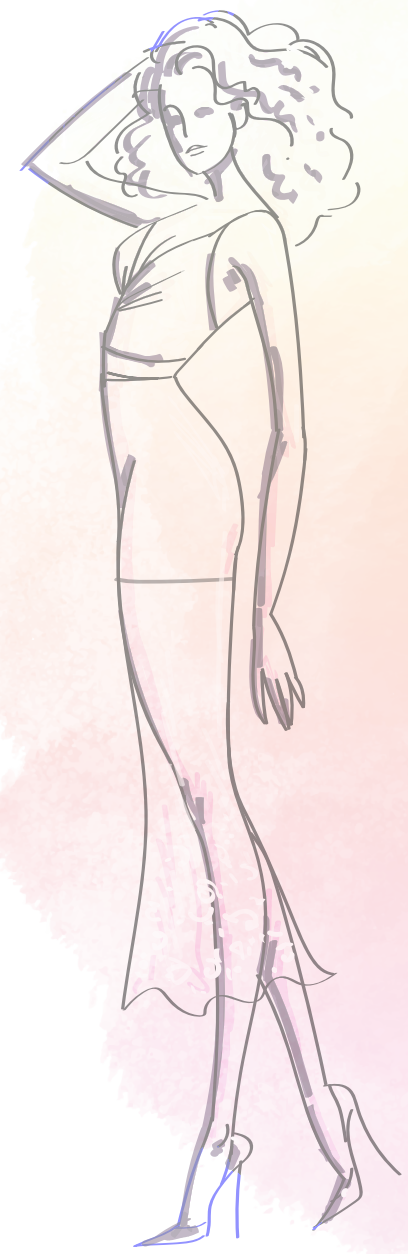

El Santuario de Nuestra Señora del Rosario de Las Lajas ubicado en Ipiales, Nariño; un templo colombiano de estilo gótico del siglo xIV, construido hace más de cincuenta años por el Arquitecto Lucindo Espinoza y bajo la dirección de Monseñor Justino Castulo Mejía y Mejía, quién, de hecho, se refiere al santuario como: "Topográficamente, el más bello del mundo. Religiosamente, el más visitado de América Latina. Arquitectónicamente, el más audaz y original de Colombia" (como se citó en Tapía, 2017).

Este templo está compuesto por tres torres terminadas en aguja, ornamentadas con grumos y frondas, típicos del estilo gótico ojival. Al igual que tres naves cubiertas de bóvedas de crucería, pilares que se entrecruzan en lo más alto de las bóvedas, grandes rosetones, estatuas, archivoltas y arbotantes.

Sus ventanales, rosetones y vitrales representan imágenes alusivas a la aparición de la Virgen del Rosario en diferentes partes de la tierra, como la Virgen de Guadalupe, la Virgen de Fátima, la Virgen de Lourdes, la de Atocha, la de Las Lajas, entre otras. (Nariño, 2016). 
El Santuario de Las Lajas es famoso por su impresionante arquitectura y una serie de leyendas relacionadas con la aparición de la Santísima Virgen, además de un mural misterioso del cual nadie conoce sus orígenes. Una de las leyendas más representativas del Santuario se remonta a 1754, cuando la Virgen del Rosario apareció frente a una mujer indígena y logró el milagro de la resurrección de su hija sordomuda.

Este lugar, considerado un símbolo de espiritualidad en América Latina y declarado la segunda maravilla de Colombia en 2007, es, ahora, una de las iglesias más visitadas por turistas peregrinos de todo el mundo.

\section{Reflexión}

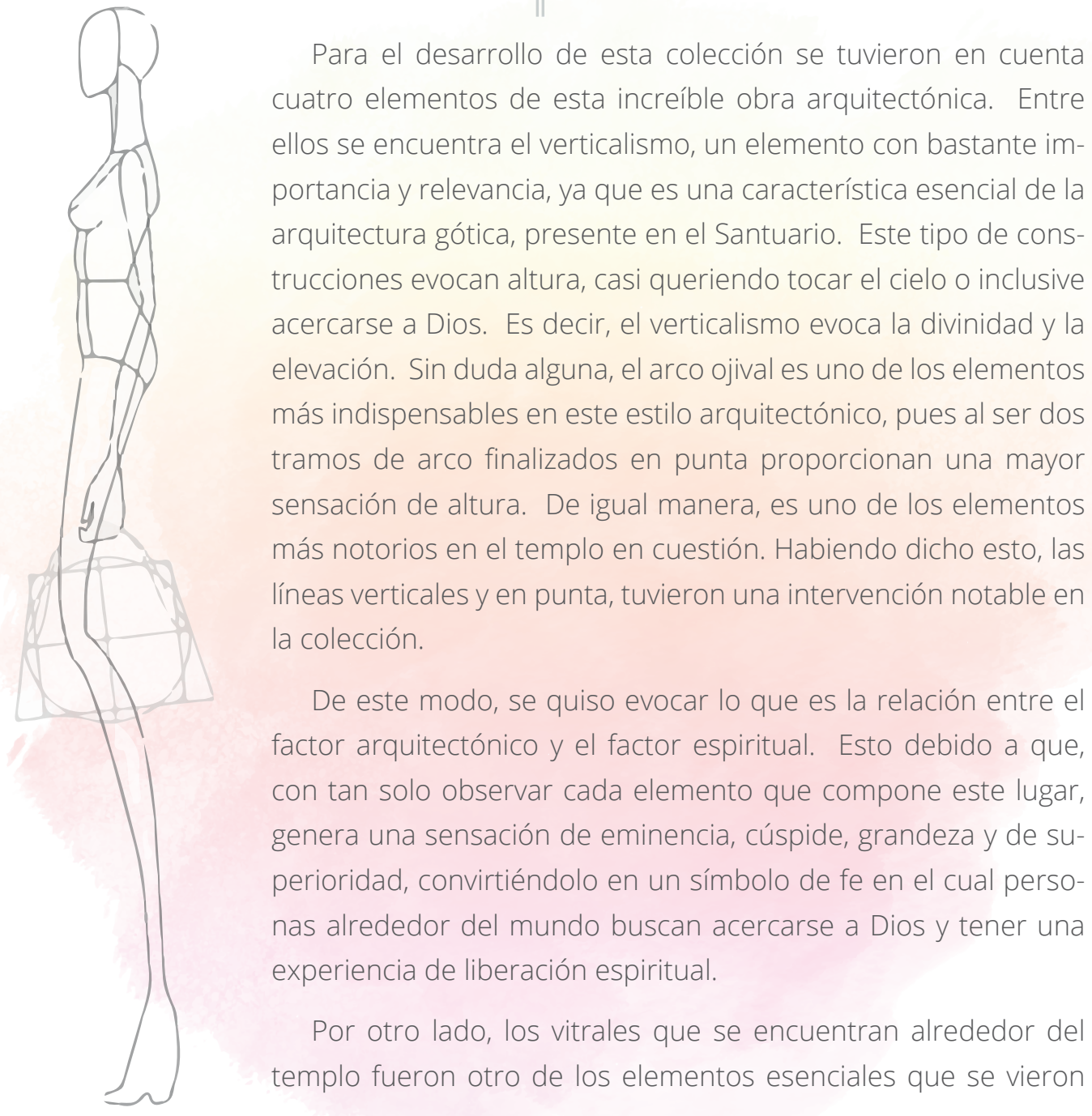




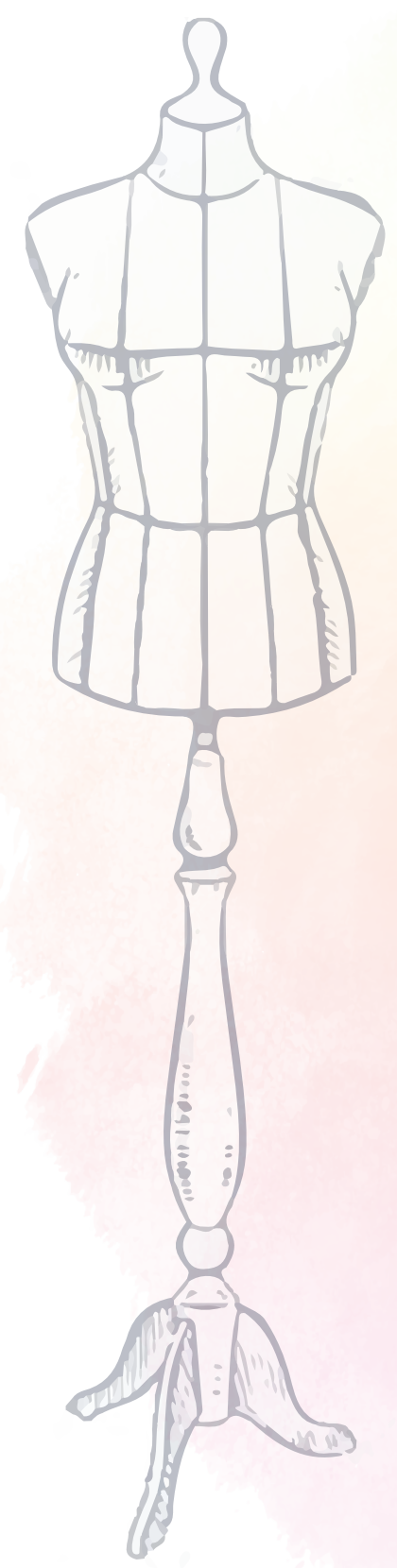

reflejados en la presente colección. Los vitrales fueron bastante notables en la Edad Media cuando se convirtieron en una forma gráfica, o pictórica, utilizada para ilustrar las narraciones de la Biblia a una población que solía ser, en gran parte, analfabeta.

A medida que la arquitectura gótica fue cambiando a una forma más ornamentada, las ventanas se hicieron más grandes, brindando así una mayor iluminación al interior. Como lo demuestra la historia, las catedrales góticas y las vidrieras que contenían fueron consideradas como "la Biblia de los Pobres". La razón de esto es porque los extractos y las historias de la Biblia se pintarán en cada una de estas ventanas de cristal. Además, como muchos de los pobres no podían leer, todos estos diferentes colores, imágenes y símbolos en el vidrio tenían un cierto significado para ellos. Este significado era, en realidad, su propia manera de aprender las Escrituras.

En el caso del hermoso Santuario gótico de Las Lajas, los vitrales realizados por el alemán Walter Wolf Wasserhouen recrean pasajes bíblicos e implementan imágenes de las apariciones de la Santísima Virgen en distintos lugares.

Además de ser estéticamente bellos, los vitrales tienen una función dentro de la arquitectura. Estos permiten la entrada de luz y una mayor iluminación dentro de la iglesia. De hecho,

La luz es un tema espiritual muy común. En el Génesis, las primeras palabras de Dios en la creación fueron: "Que exista la luz'. Y la luz existió. Dios vio que la luz era buena" (Génesis 1,3-4). Con esto en mente, era apropiado que los creyentes dedicaran mucho tiempo y energía a desarrollar el diseño de las ventanas en las iglesias. Las ventanas canalizan la luz del sol y disipan las tinieblas de las sombras. Los arquitectos vieron en ellas una oportunidad perfecta para destacar una verdad espiritual al tiempo que servían a un propósito funcional. (Kosloski, 2017) 
Independientemente del papel de los vitrales en las iglesias, sea para la decoración o para representar pasajes bíblicos, estas también representan muchas otras características, como el simbolismo detrás del uso de ciertos colores. Entrar a una catedral gótica en un día soleado es como entrar en un arco iris. Los rayos de luz que atraviesan los vitrales reflejan en el interior de la iglesia tonos rojos, azules, verdes y púrpuras.

En las iglesias de estilo gótico, los colores utilizados en las vidrieras que las adornan son de suma importancia. Varios estudios arte en vitrales, han explicado el significado y el simbolismo detrás del uso de los colores en vitrales religiosos.

El color rojo representa la sangre de Jesús e indica su sufrimiento y sacrificio; el color azul simboliza el cielo, la esperanza, la sinceridad y la piedad; el color verde es un indicio de crecimiento y renacimiento, simboliza la fe, la inmortalidad y la contemplación; el color violeta simboliza amor, verdad, pasión y sufrimiento; el blanco es el color que representa la inocencia y la pureza asociada con Dios y la Virgen María; el amarillo es usado en ocasiones para simbolizar la traición de Judas, sin embargo, normalmente simboliza la divinidad, el poder y la gloria; el color púrpura se usa para representar el sufrimiento y la resistencia; y por último, el color gris es símbolo de humildad y luto.

En el Santuario de Las Lajas, los colores que predominan en los vitrales son el rojo, el verde y el púrpura. En la presente colección, se vieron interpretadas las formas orgánicas y geométricas características de los vitrales, dándole de esta manera un estilo arquitectónico y geométrico a la colección.

Como tercer elemento, se encuentra el término que representa al Santuario en su totalidad: milagro. Es innegable que esta iglesia es una maravilla en medio de la naturaleza. Se encuentra construida en medio del cañón en la cordillera de Los Andes, a 2.900 metros sobre el nivel del mar. Esta increíble obra arquitectónica fue construida gracias a las historias y hechos fantásticos que se dieron lugar en esta montaña, ya que muchos lo consideraron un lugar sagrado.

Estos milagros conmocionaron a toda la población, al punto que la leyenda se mantuvo durante siglos y ese lugar, en medio del cañón del Guaitará, se convirtió en un lugar de peregrinación.

Pero fue recién en 1915 que una capilla de tabla empezaría a convertirse en el majestuoso santuario que es hoy en día. Ha sido tan relevante la Virgen de las Lajas y han sido tantos los milagros que se han dado que su historia llegó a oídos del Vaticano.

Los milagros de Santa María del Rosario en las Lajas motivaron a que, en 1951, la iglesia católica canonizara a la Virgen de Las Lajas y nombrara al Santuario basílica menor. (Patiño, 2018) 


\section{Conclusiones}

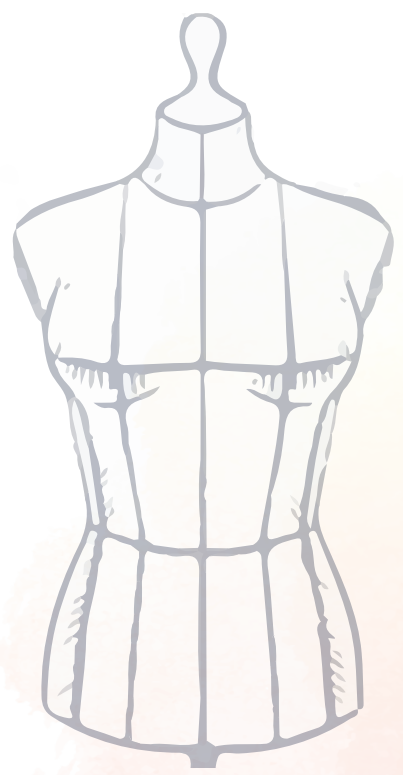

La belleza y majestuosidad que evocan, tanto la arquitectura como el ornamento, e incluso la historia de este Santuario, fue la base para llevar a cabo esta colección, la cual está destinada a una mujer segura, fuerte y empoderada, lo mismo que se puede percibir al observar la Iglesia. Por lo tanto, en la presente colección se ven reflejados todos aquellos aspectos relevantes de este maravilloso lugar, reconocido mundialmente por su bella arquitectura, su inigualable historia y el increíble punto geográfico en el que se encuentra ubicado; convirtiéndolo así en la Santuario más icónico de Colombia. En este caso, representado a través del diseño, la interpretación simbólica y, por supuesto, la Moda.

\section{Tercer semestre: diseño textil aplicado en masculino casual}

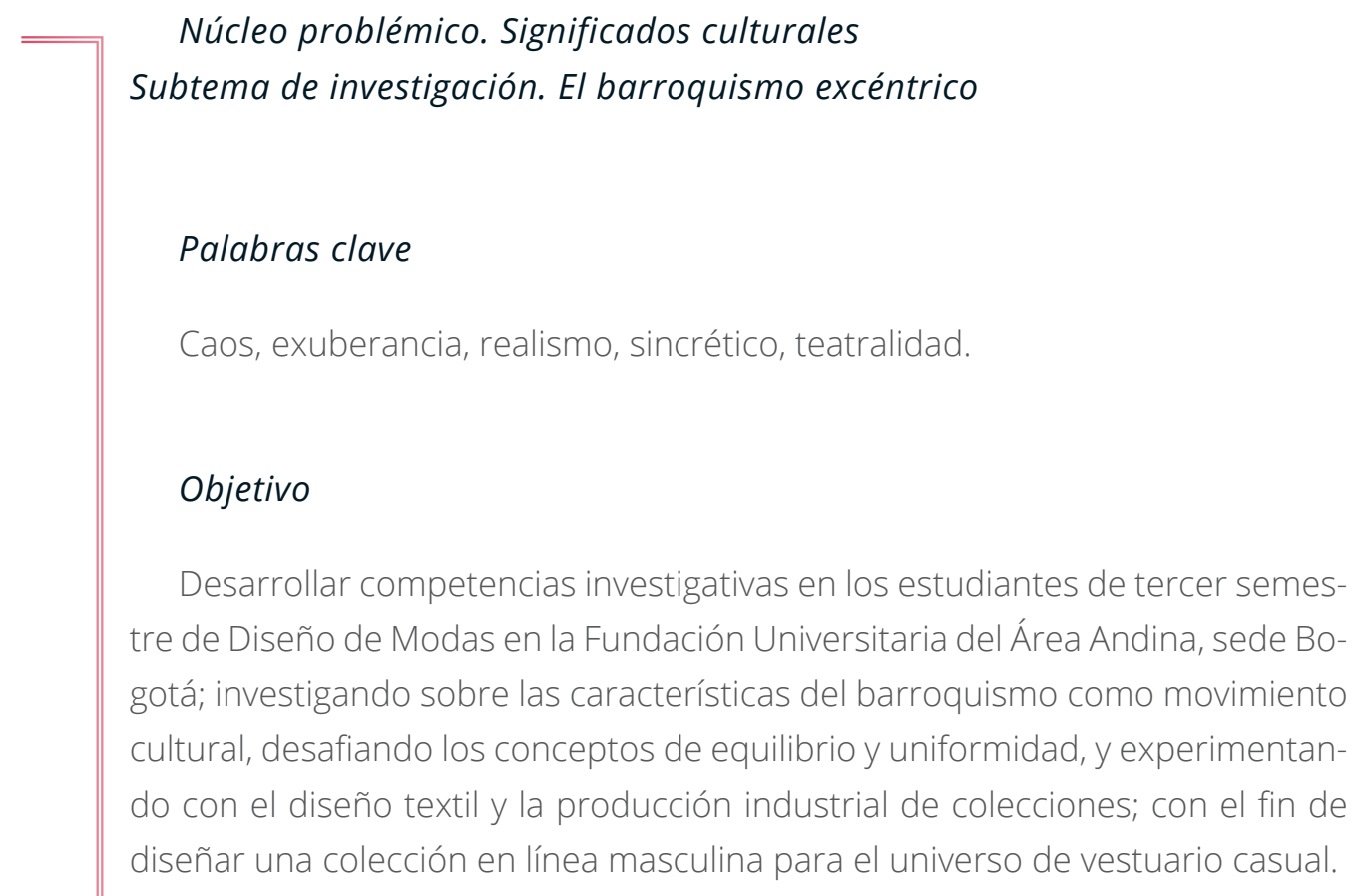




\section{Entregables}

» Semana 8

» Artículo de investigación

» Moodboard de concepto

» Bitácora de diseño

» Una camisa en denim masculina casual, con intervención textil

» Semana 15

» Bitácora de experimentación textil. Fichas técnicas bases textiles (20)

» Bitácora de diseño de colección y de diseño de calzado

» Dibujos a plano. Usando reglas a 1/4/4 de escala

» Aplicación de macrotendencias (materiales textiles y cartas de color)

» Semana 16

» Friso de colección. Diez ilustraciones delantero y posterior. Formato análogo

» Tamaño 1/8 horizontal. Gramaje y papel entre 180 gr y 230 gr (opalina o cartulina), técnica a convenir.

» Un indumento masculino casual compuesto por camisa, pantalón, chaqueta sport. Con intervención textil y calzado.

\section{Bases textiles}

Denim.

\section{Entregas finales}

Ver, de la figura 5 a la figura 12. 


\section{FIGURA 5}

DISEÑO TEXTIL. MASCULINO CASUAL. LAURA YÁÑEZ.

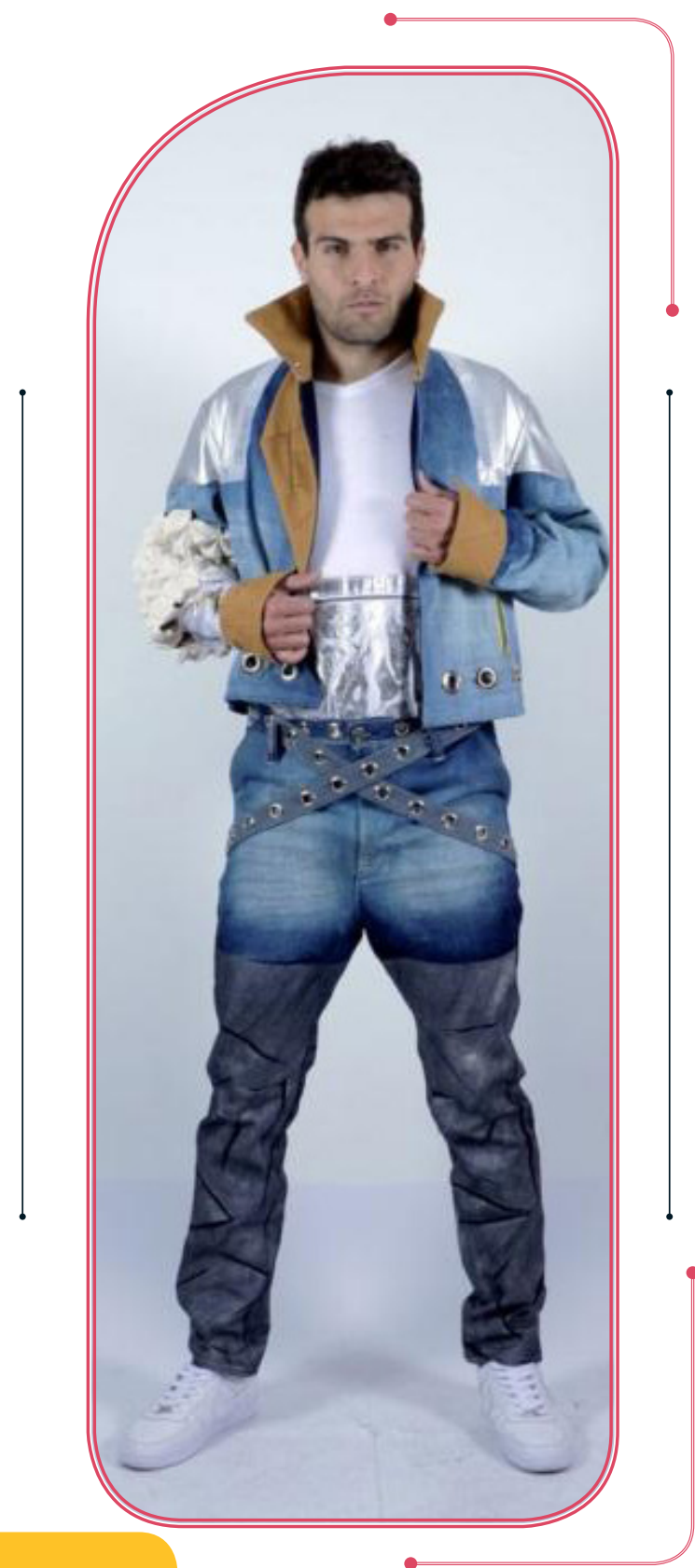

Fuente: Auditorio Fundación Universitaria del Área Andina, sede Bogotá.

Programa de Diseño de Modas León, 2019. 
FIGURA 6

DISEÑO TEXTIL. MASCULINO CASUAL. STEFANNY LEÓN

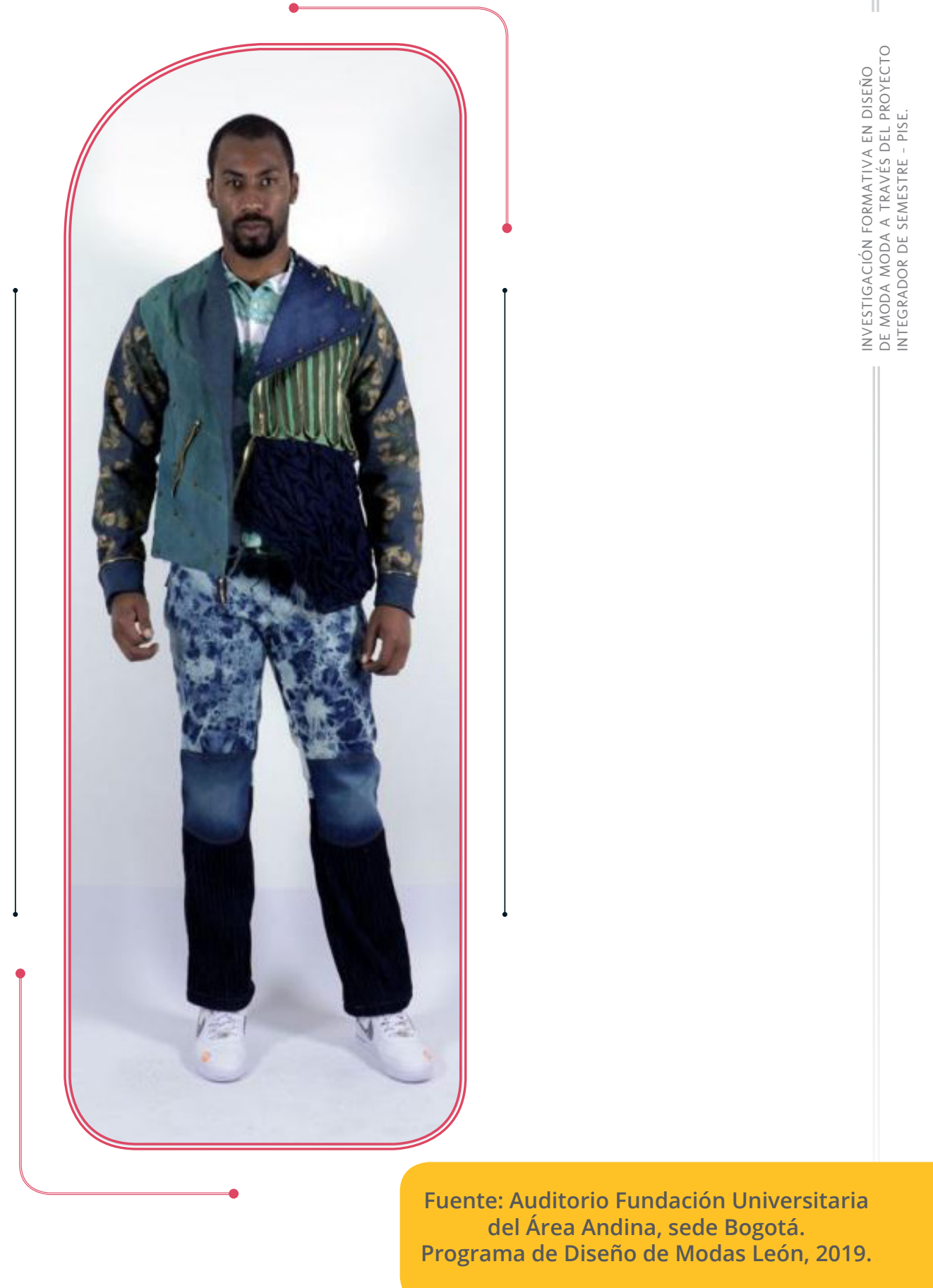




\section{FIGURA 7}

DISEÑO TEXTIL. MASCULINO CASUAL. LIZETH JIMÉNEZ.
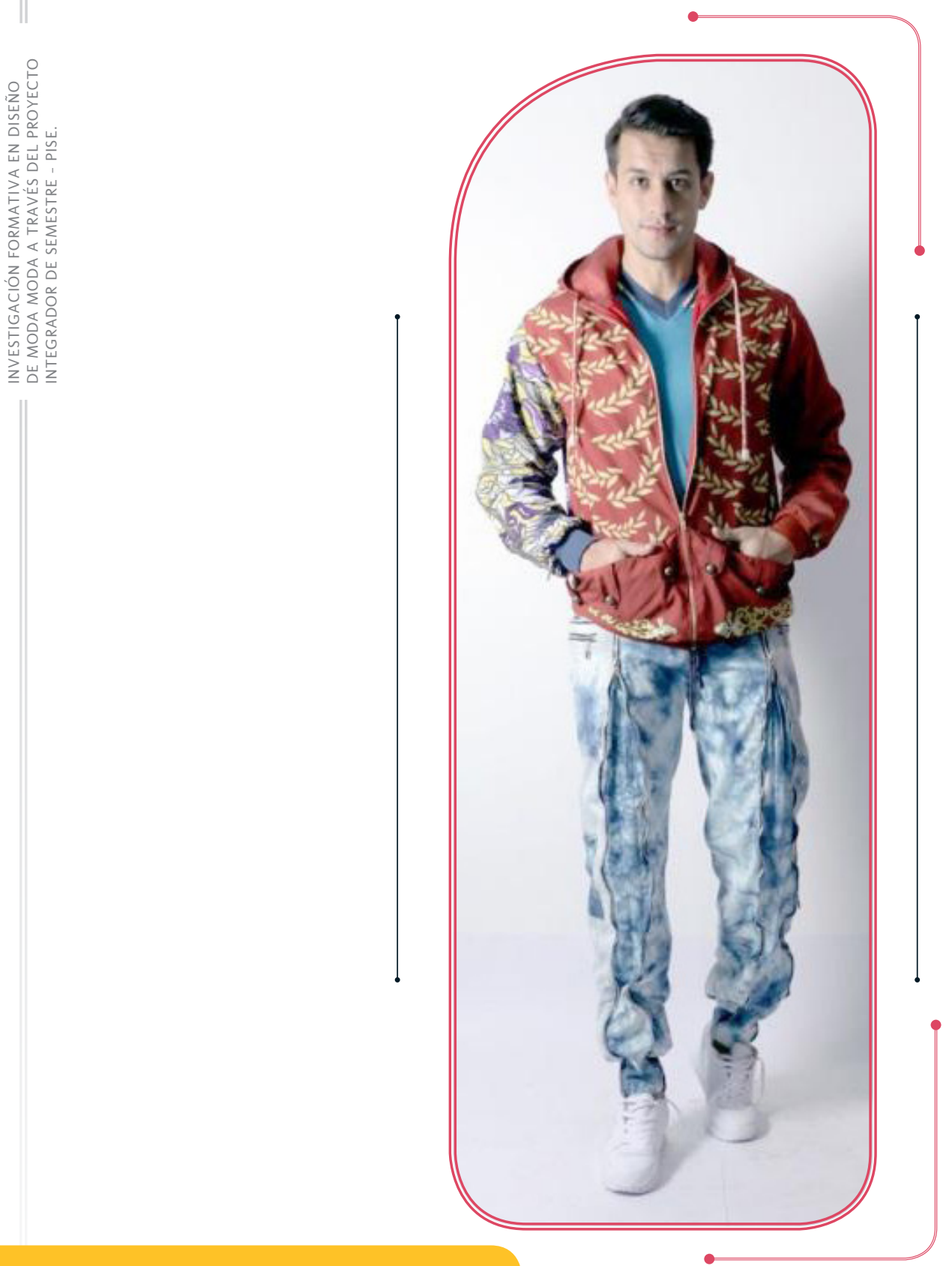

Fuente: Auditorio Fundación Universitaria del Área Andina, sede Bogotá.

Programa de Diseño de Modas León, 2019. 


\section{FIGURA 8}

DISEÑO TEXTIL. MASCULINO CASUAL. KEVIN LOZANO.

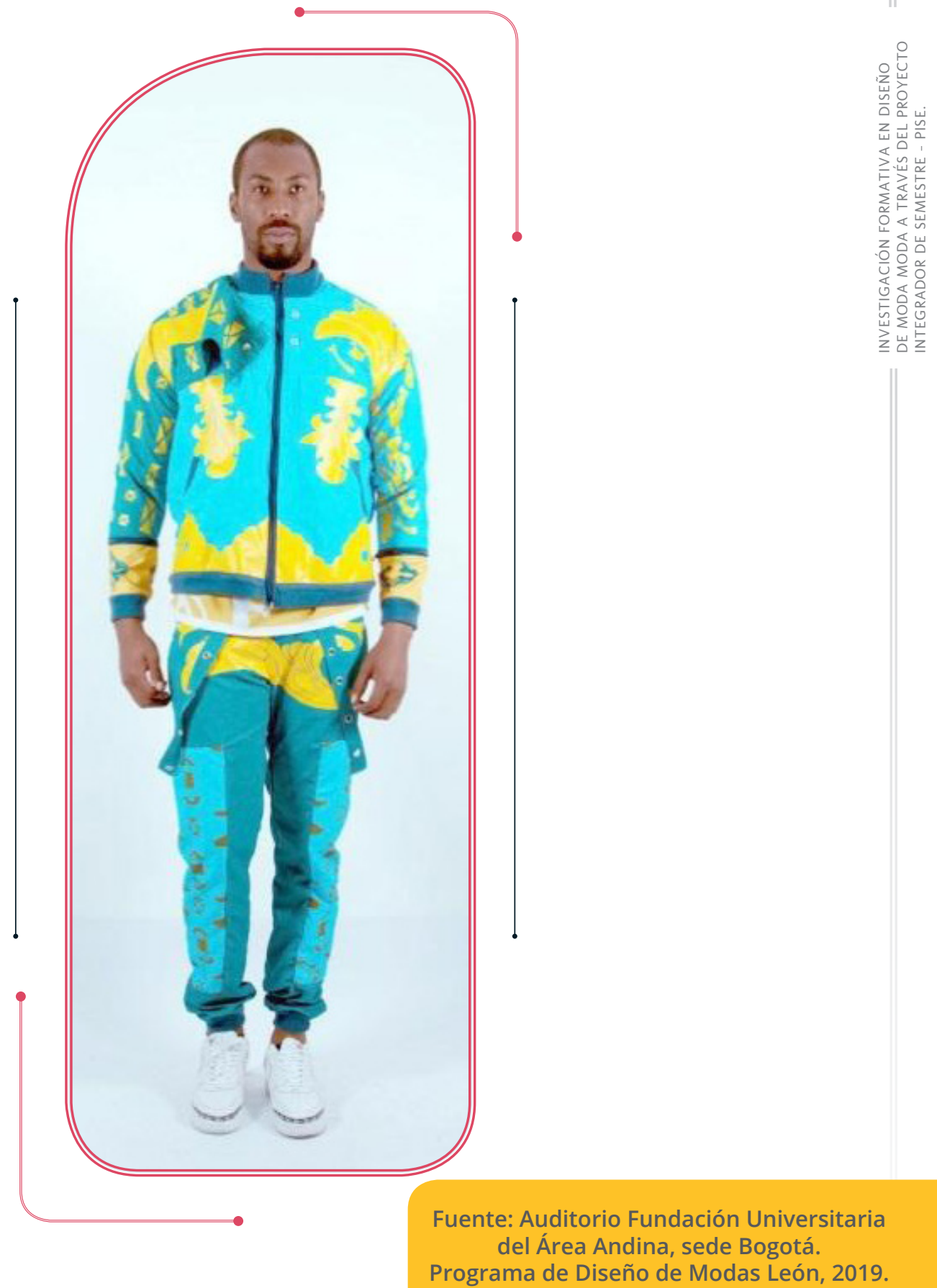


FIGURA 9

DISEÑO TEXTIL. MMASCULINO CASUAL. NATALIA MÉRIDA.
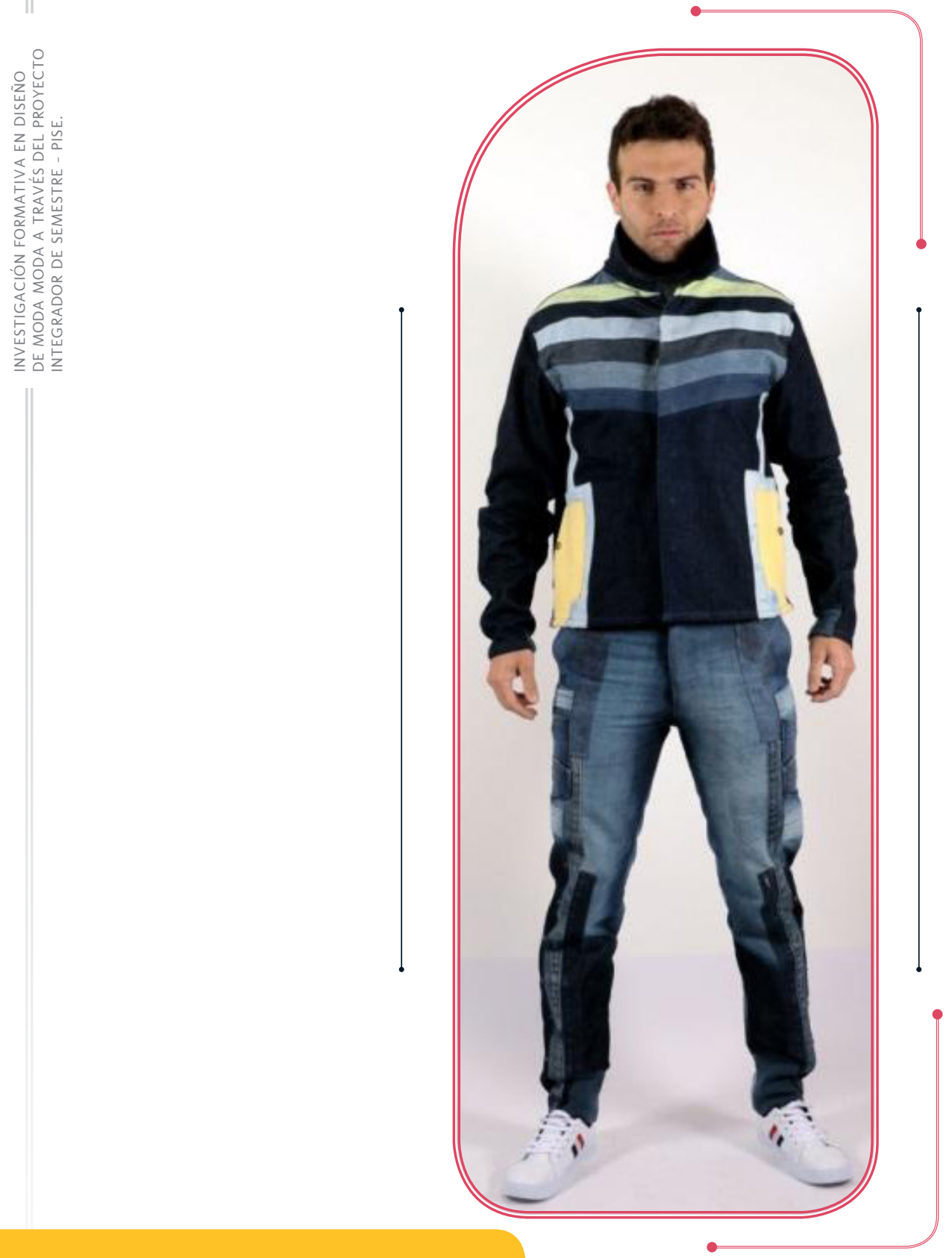

Fuente: Auditorio Fundación Universitaria del Área Andina, sede Bogotá.

Programa de Diseño de Modas León, 2019. 


\section{FIGURA 10}

DISEÑO TEXTIL. MASCULINO CASUAL. SOFÍA PARRA.

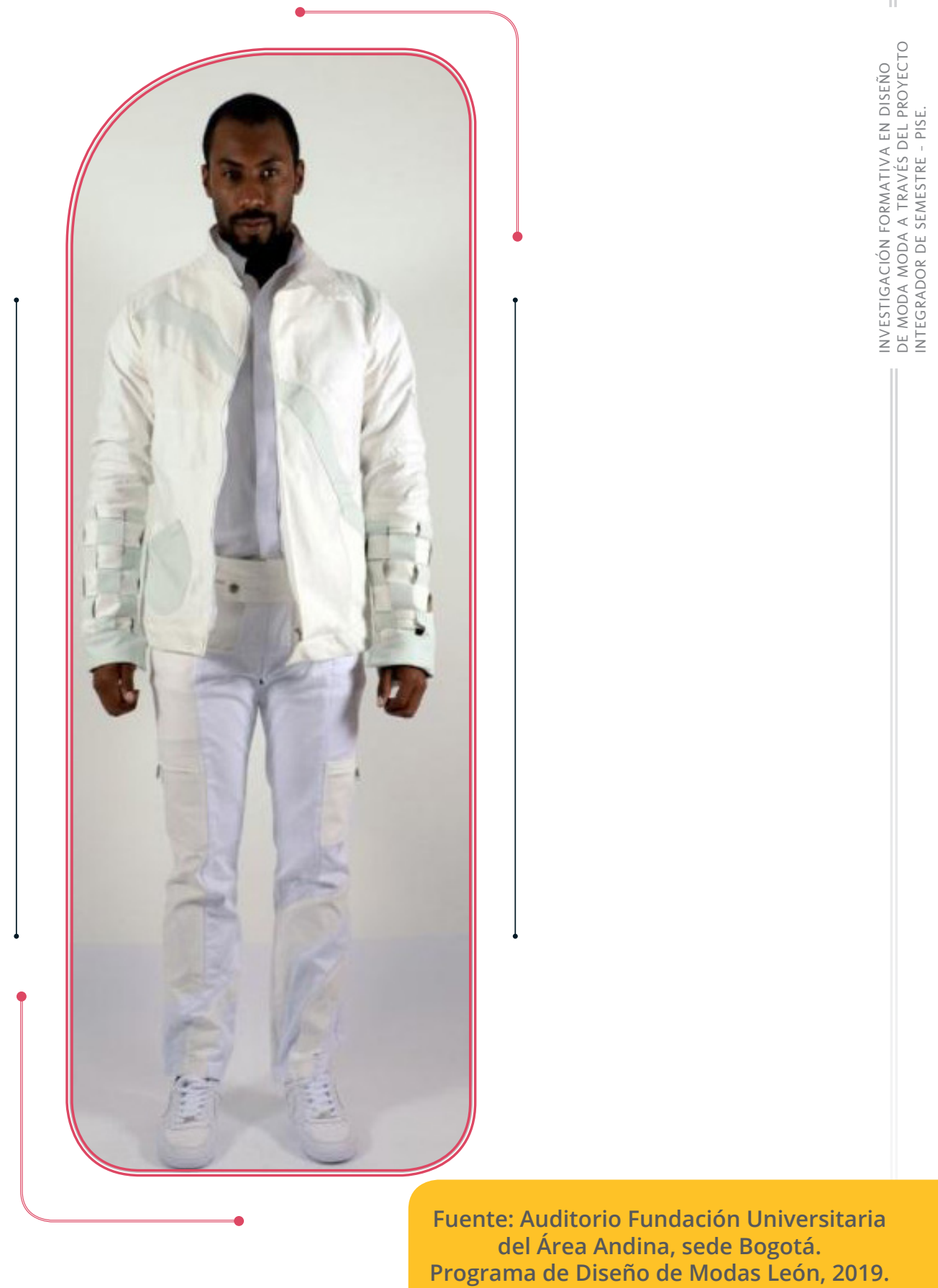




\section{FIGURA 11}

DISEÑO TEXTIL. MASCULINO CASUAL. SILVIA MARTÍN.
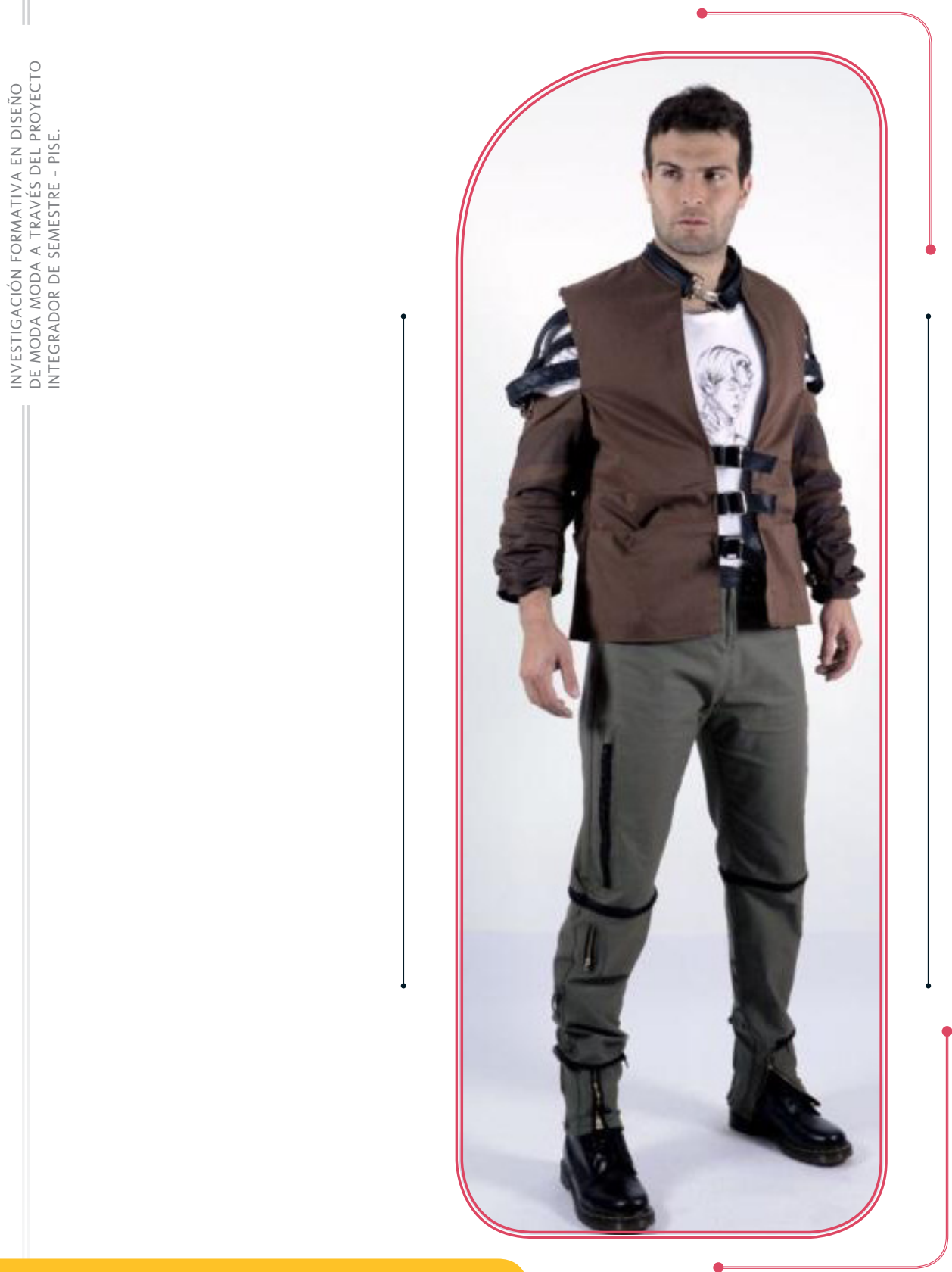

Fuente: Auditorio Fundación Universitaria del Área Andina, sede Bogotá.

Programa de Diseño de Modas León, 2019. 
FIGURA 12

DISEÑO TEXTIL. MASCULINO CASUAL. LAURA TORRES.

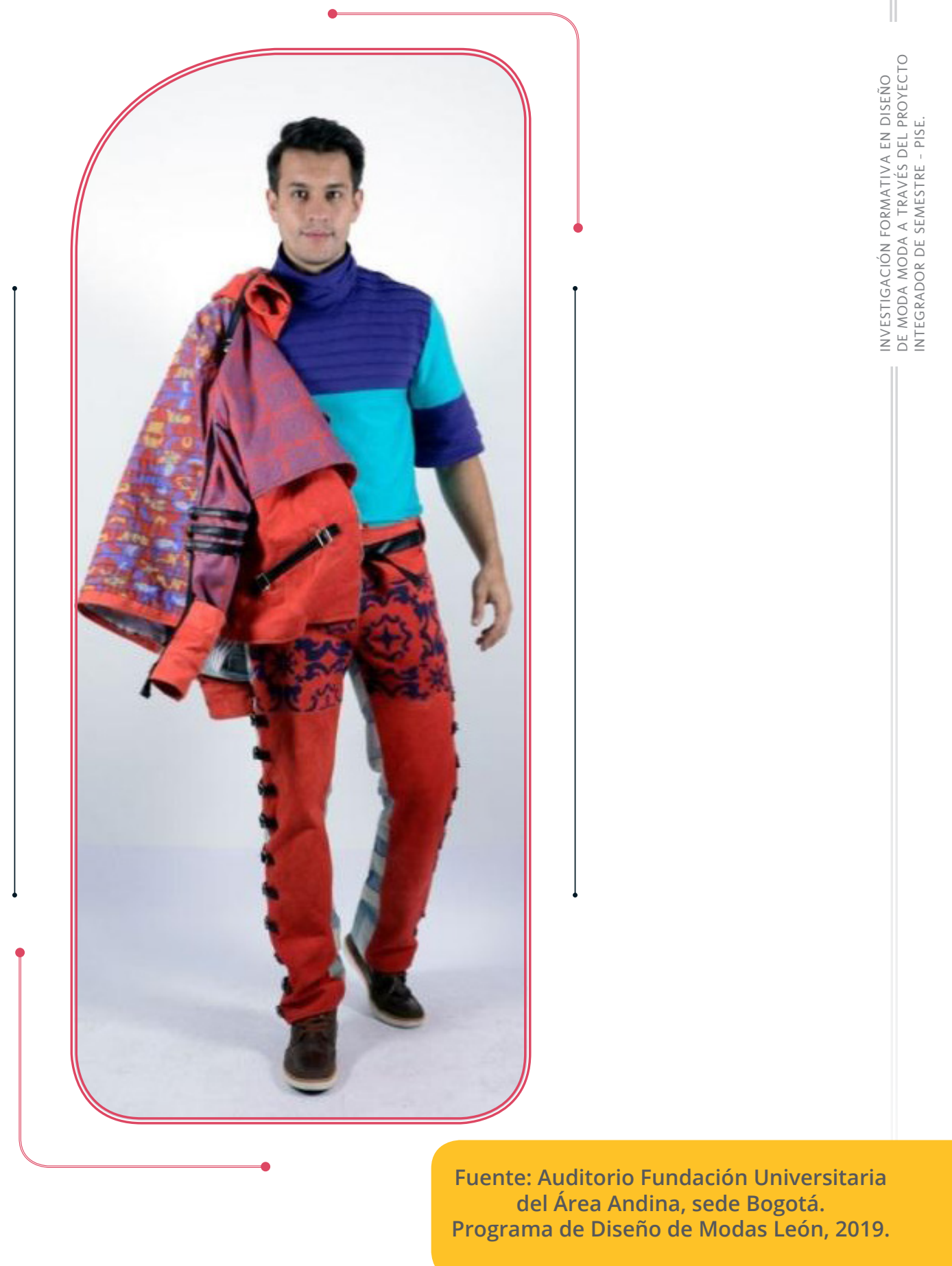




\section{FIGURA 13}

DISEÑO TEXTIL. MASCULINO CASUAL. GERALDYN HOYOS.
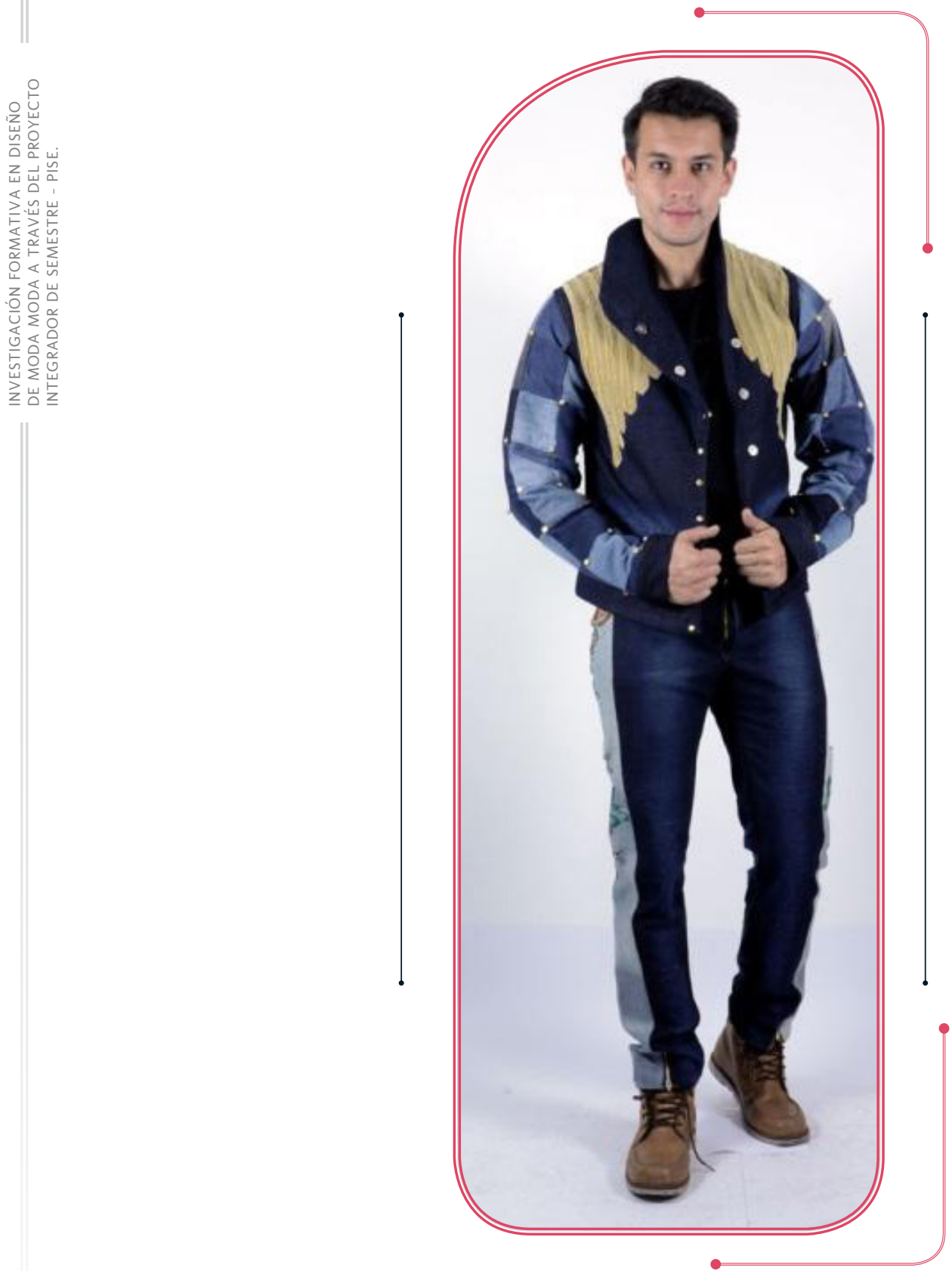

Fuente: Auditorio Fundación Universitaria del Área Andina, sede Bogotá.

Programa de Diseño de Modas León, 2019. 


\section{FIGURA 14}

EXPERIMENTAL FEMENINO. VALERIA CORSO CRUZ.

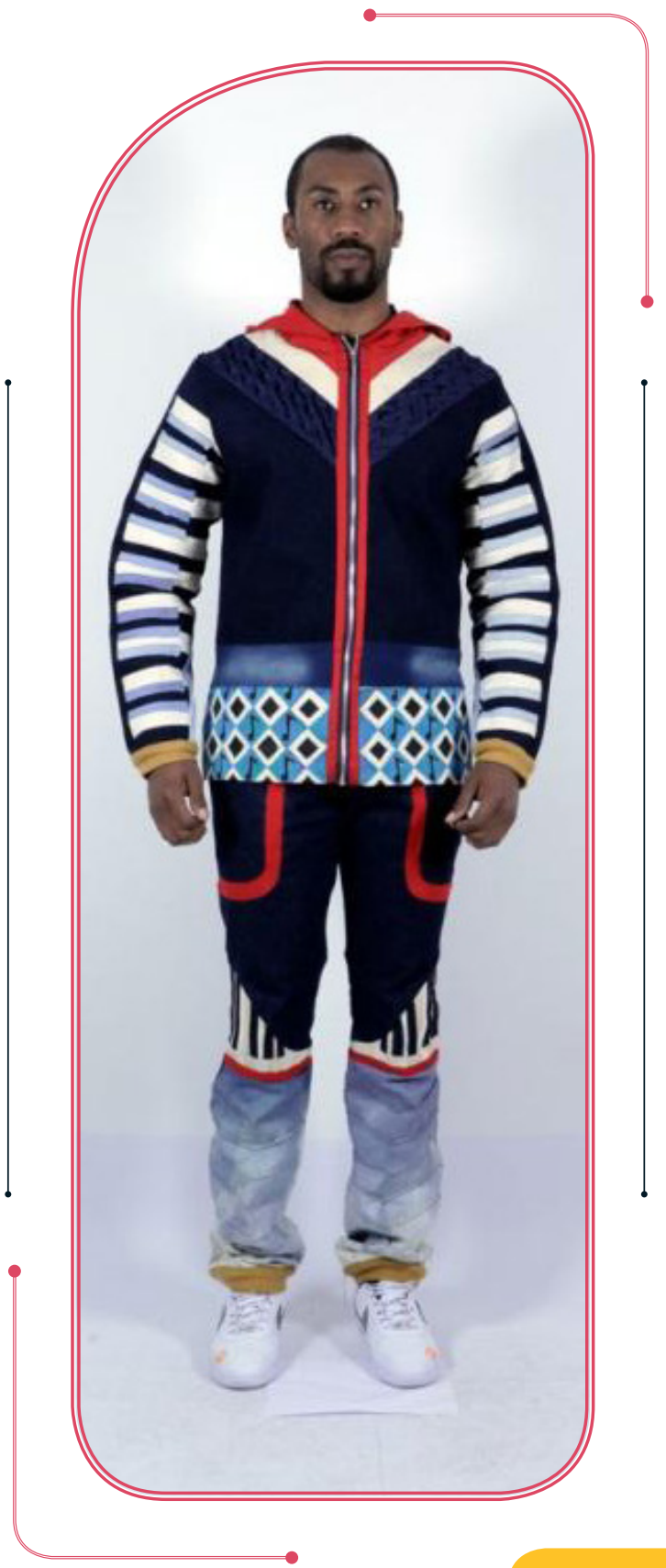

Fuente: Auditorio Fundación Universitaria del Área Andina, sede Bogotá.

Programa de Diseño de Modas León, 2019. 


\section{FIGURA 15}

DISEÑO TEXTIL. MASCULINO CASUAL. MATEO JIMÉNEZ.
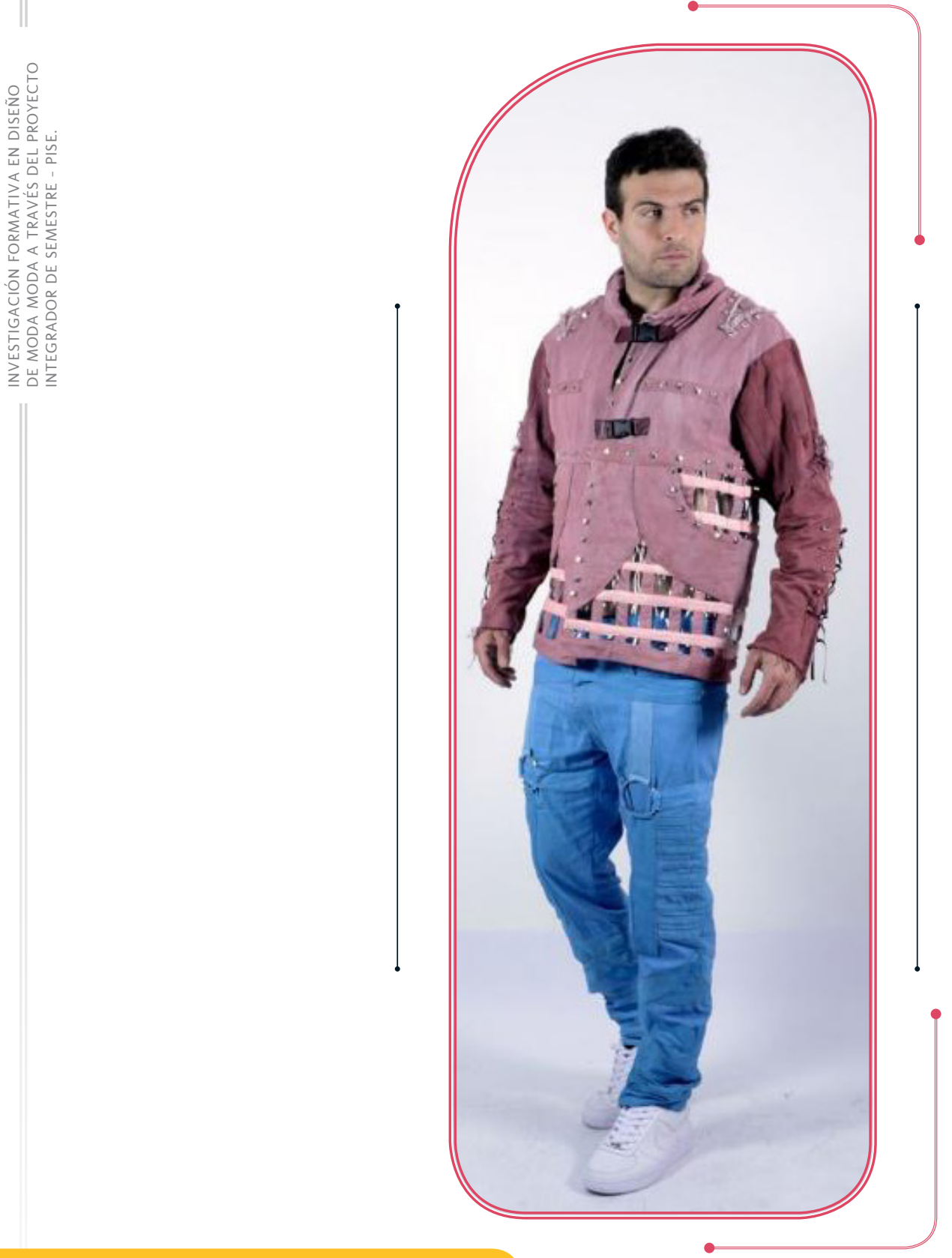

Fuente: Auditorio Fundación Universitaria del Área Andina, sede Bogotá.

Programa de Diseño de Modas León, 2019. 


\section{Artículo resultado final: Ascender "Escalinata de Santa María del Monte". El poder del arte y la cultura en la moda. Laura Daniela Torres Rincón}

"Caltagirone, muy por encima de la colina que se arremolina al cielo" (Sicily).

\section{Resumen}

Conectar saberes, arte y creatividad, es la inspiración a nivel de la facultad de Diseño, Comunicación y Bellas, del que se subdivide el barroquismo excéntrico, a nivel de tercer semestre. La colección Ascender tiene, como inspiración personal, manejada en este caso "La Escalinata de Santa María del Monte" que se ubica en Caltagirone, Sicilia y que es considerada el principal punto de interés de esta ciudad ya que es un símbolo de la historia de la cerámica de Caltagirone en los últimos diez siglos y debe su nombre a la iglesia Madre de Santa Maria del Monte.

A lo largo del artículo se contará todo el proceso de desarrollo de esta colección, desde la investigación del referente del barroco que es la escalinata, desglosando aquellos conceptos que definen y representan la inspiración, además de la identificación de las tendencias, procesos manuales textiles, perfil y visionario, textiles para poder realizar una colección masculina para la temporada primavera/ verano 2020 del universo casual jeanswear que consta de diez atuendos conformados por chaqueta, pantalón y camisa o camiseta, y de los cuales se confecciona uno de ellos y se realiza una bitácora con todos los atuendos ilustrados y con toda la información del proceso de diseño.

\section{Palabras claves}

Arquitectura, barroco excéntrico, Caltagirone, cerámica, color, escalinata, figuras geométrica, seanswear, Sicilia.

\section{Introducción}

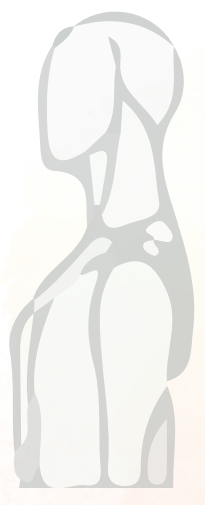

Ascender, es una colección masculina para la temporada primavera / verano 2020 del universo casual jeanswear que tiene como punto de inspiración a la Escalinata de Santa María del Monte que se ubica en Caltagirone, Sicilia (Italia). Este referente personal nace de la inspiración Conectar saberes, arte y creatividad, a nivel de la facultad y del barroquismo excéntrico, a nivel de tercer semestre de la carrera de diseño de modas, a su vez, este se dividió en diferentes subtemas 
clasificados de la siguiente forma: arquitectura, pintura, música, decoración y joyería. Esta escalinata es una obra de arte creada y construida por ceramistas locales y cuya proyección inició en el siglo xvii con el objetivo de conectar los tres puntos más importantes de la ciudad, los cuales son: la ciudad baja (piano di San Giuliano), la ciudad alta y el centro histórico. La escalinata está formada por 142 escalones de piedra fundida, cada uno decorado con baldosas en mayólica. La cerámica utilizada se encuentra en naranja, verde, azul y amarillo que son los colores típicos de Caltagirone. Las baldosas de cada escalón están decoradas con diseños geométricos y figuras que representan la tradición local y estos motivos fueron obtenidos por Antonio Ragona.

Teniendo en cuenta estas características, se realizó una investigación para el desarrollo de la colección, guiada por la tendencia secuencia creativa primavera / verano 2020 de WGSN, inspirada por la unión de la cultura y el arte. Esta colección se dirige a un perfil contemporáneo, con un estilo propio, seguro de sí mismo que sueña en grande.

El proceso de diseño de esta colección inició con la investigación sobre el punto de inspiración: la Escalinata de Santa María del Monte, considerada uno de los principales sitios de interés en Caltagirone, de esta manera, se quiere reflejar en esta colección, la historia, la tradición y el arte que demuestra a través de la armonía de sus formas y colores.

Expresado por medio de procesos textiles manuales la superposición, repetición, rotación, gradación y contraste de texturas, figuras y colores que genera un impacto visual propio del barroquismo excéntrico que llega al caos y a lo recargado, pero sin perder la esencia del objeto de estudio ya que se maneja este concepto de época pero traído a la modernidad. 


\section{Método}

"El barroco es un estilo artístico que dominó la arquitectura, la pintura, la literatura y la música en Europa durante el siglo xvii." (Diana, 2014).

Según Profe en Historia, el barroco es la cultura comprendida en ese período (siglo xvii) que abarca costumbres, tradiciones, valores, relaciones sociales, entre otros aspectos. El barroquismo nació en Italia en el siglo xvii y se extendió por Europa (Bélgica, Francia, España, etc.), fue un movimiento artístico que se mantuvo hasta el siglo xviii, que se dio a finales del Renacimiento y se representó por medio de detalles ostentosos y extravagantes en las clases altas, quienes obtenían sus riquezas de la colonización.

Las características que reflejan la esencia del barroquismo son:

Arte que expone el gusto por lo elegante, lo extravagante y el exceso de ornamento, valorización del detalle, exceso de ornamento, búsqueda de la espiritualidad, de las sensaciones y las pasiones internas, dualismo y contradicción, contraste entre luces y sombras, sentido del movimiento, oscuridad, complejidad y sensualismo y en literatura, cultismo y conceptismo. (Diana, 2014).

La arquitectura en el período barroco fue una expresión contra la religión católica por medio del arte. La manifestación abarca el barroquismo que inició en Roma (1600) llegando a Europa y América Latina, una característica muy importante fue la contribución al arte ya que fue una revolución urbanística. El principal punto de interés de la arquitectura barroca son las iglesias, catedrales y los monasterios, ya que estos reflejan la imponencia del arte cristiano. En ese tiempo se realizó la construcción de parques y jardines para cercar las residencias de gran importancia, a raíz de esto, disponer de edificaciones y de reorganizar la parte urbana exigió una planificación con la que no se contaba en el momento.

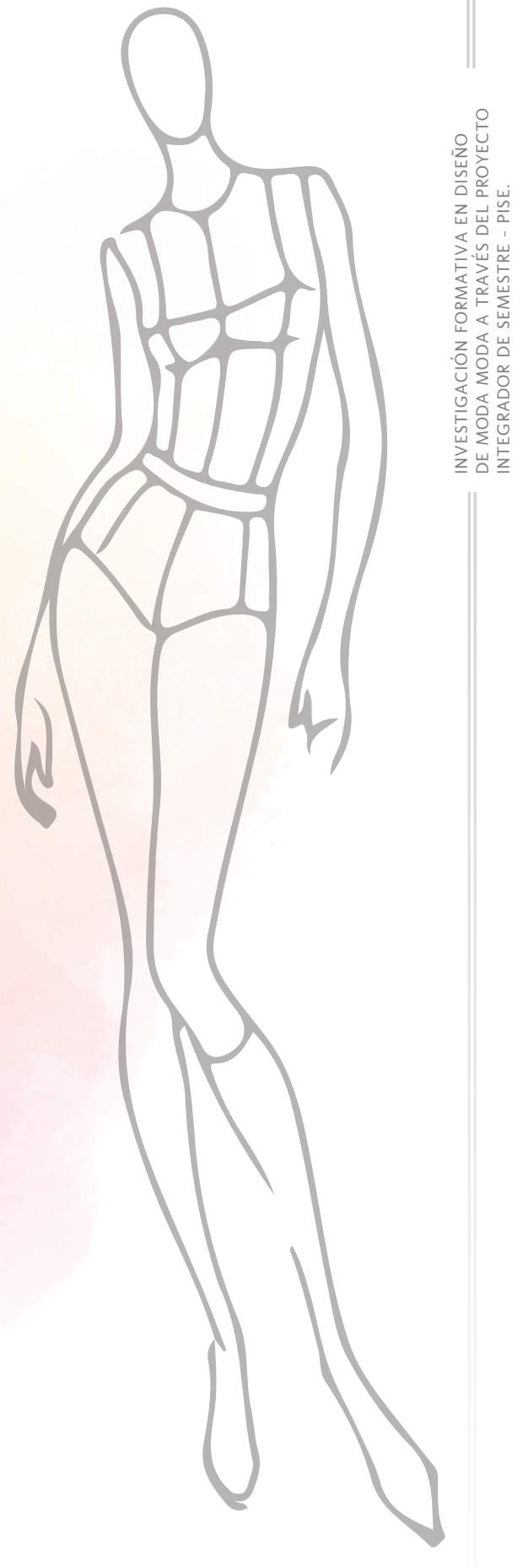


Para los arquitectos, la arquitectura barroca y todas las edificaciones eran como el arte de la escultura.

Las características que definen a la arquitectura barroca son:

Extravagancia, inusual e irregular, uso del movimiento, proximidad del real, aplicación de la curva en oposición a la idea estática de los edificios, las iglesias del período barroco están formadas por bóvedas, arcos y contrafuertes, tentativa para que el observador se imagine en el infinito, efectos escenográficos teatrales, mezcla de la pintura y escultura y manipulación de la luz. (Historia, 2018).

Italia es uno de los principales países en donde se desarrolló el movimiento del barroco, de esta manera, en Sicilia se dio el barroco siciliano que fue distintivo de la arquitectura barroca que se desarrolló en el sur de las costas de la isla en los siglos xvii y xviii. El estilo se reconoce no sólo por sus típicas curvas y florituras barrocas, sino también por sus máscaras sonrientes y puttis con la particular extravagancia que le ha dado a Sicilia una identidad arquitectónica única.

Caltagirone es una de las ocho ciudades del sureste de Sicilia conocidas como las ciudades barrocas de Val di Noto, que fueron destruidas y reconstruidas casi por completo después del terremoto de 1693 y clasificadas como patrimonio de la humanidad por la UNESCO. (Italy, 2014).

Caltagirone está ubicada en el interior de Sicilia y es una ciudad rica en arcilla, lo que le ha dado el reconocimiento a nivel mundial por producir, de forma artesanal, cerámica. Los artesanos toman el nombre de Cannatan y con el pasar de los años han evolucionado y perfeccionado la producción de esta, pero sin dejar de lado los diseños moriscos y los colores característicos de la ciudad (verde, manganés, turquino, amarillo y oro). Los patrones ornamentales sobre un fondo blanco son similares a los antiguos bordados y tejidos sicilianos y la decoración de telas, en violeta, verde, naranja-amarillo, colores azul cobalto, que recuerdan los brillantes paisajes sicilianos. Los siglos xv-xvii se consideran la edad de oro de La ciudad de la Cerámica.

En 1693, un terremoto catastrófico destruye Caltagirone, con la reconstrucción de la ciudad también el arte de la cerámica vuelve a vivir con nuevos impulsos artísticos. La tradición de la cerámica es visible en cada parte de la ciudad, no solo en sus numerosas tiendas, que venden cerámica y maíz, sino también en toda la arquitectura de la ciudad, balaustradas, jarrones y otros elementos decorativos de cerámica que realzan las calles de la ciudad barroca. El más famoso son las magníficas escaleras de Santa María del Monte en el centro del pueblo. 


\section{Escalinata de Santa María del Monte.}

Construida en 1606, las asombrosas escaleras de Santa María del Monte conectan la parte antigua de la ciudad con la más nueva. A ambos lados de las escaleras se encuentran los dos barrios antiguos de San Giorgio y San Giacomo. Las escaleras constan de 142 escalones, cubiertos con coloridas cerámicas esmaltadas. Los pasos inferiores muestran la cerámica más antigua, mientras que los más nuevos se encuentran en la parte superior de las escaleras. Las escaleras deben su nombre a la Iglesia Madre de Santa María del Monte, antigua sede de la autoridad religiosa, que se encuentra en la parte superior de las escaleras.

Los motivos de la mayólica de las escaleras se alternan constantemente entre una fila de azulejos con un patrón floral u orgánico, una fila de patrones geométricos y una fila de patrones decorativos figurativos (especialmente en la mitad inferior de las escaleras).

Las escaleras se celebran tres veces al año; la infiorata durante el mes de mayo, se realiza el "Festival de las flores" dedicado a la virgen María. Miles de flores son utilizadas como adornos, a lo largo de la escalera. La Scala Iluminata con motivo de celebrarse la fiesta en honor a Santiago el Mayor, patrono de Caltagirone, durante los días 24 y 25 de julio y el 14 y 15 de agosto de cada año, se realiza la iluminación artística de la escalinata, con 4000 lámparas de aceite. El espectáculo congrega a un gran número de visitantes. Y en Navidad, las escaleras están decoradas con ciclamen y estrellas de Navidad. (Italy, 2014)

El proceso de diseño conllevó una serie de investigaciones, metodologías, evolución y entregas, que 
constituyeron el camino que llevó al desarrollo y construcción del atuendo del diseño final. Se inicia con la investigación del tema a nivel semestre que es el barroquismo excéntrico. Se investiga este concepto teniendo en cuenta su definición, características, época, referentes y todos los aspectos que giran en torno a este. Con la información obtenida se divide el concepto en los siguientes subtemas: arquitectura, pintura, literatura, música, joyería y decoración para poder encontrar el punto de inspiración personal que en este caso es la Escalinata de Santa María del Monte.

Al momento de tener el referente, se procede a realizar dos moodboards: uno de conceptos formales y otro de conceptuales, que consisten en una composición de imágenes que ayudan y sirven de guía y soporte gráfico de la inspiración para la construcción de la colección. Luego de tener estos dos moodboards se realiza una fusión de estos, seleccionando aquellas imágenes y conceptos que mejor describen y representan el punto de inspiración y es el que irá en la bitácora final junto con los diseños.

Con las características y la información obtenida de la escalinata se realiza la bocetación inicial sobre figurín a dibujo plano de las chaquetas. Se comienza con los bocetos de cinco de las diez chaquetas, sólo delantero, de la colección, teniendo en cuenta los conceptos utilizados en el moodboard final. Para la realización de los diseños se tuvo en cuenta aquellos aspectos importantes que facilitaron la creación de estos. Entre los que se encuentran algunos fundamentos del diseño básico, al igual que los elementos para el desarrollo del diseño entre los que están la silueta, proporción, función y los detalles. Todo esto, teniendo presente con las competencias adquiridas tanto en primer como segundo semestre.

Se busca un perfil al que va a ir dirigido la colección y un visionario; este se debe asemejar a los diseños de los atuendos. Con esta información se realiza un moodboard de perfil-visionario en el que, por parte del perfil, se muestra un estilo de vida, y el visionario es aquella guía y referente para el desarrollo de la colección.

Se continúa con la realización de las ilustraciones de los diez atuendos, diez chaquetas y diez pantalones, tanto delantero como posterior, que conforman la colección final, teniendo presente que las chaquetas deben tener innovación en solapa, manga, puño, bolsillo, sistema de cierre y texturas; y los pantalones innovación en bota, pretina, bolsillos y texturas; que están basadas en el referente teniendo en cuenta las figuras, texturas pero teniendo presente que sea funcional, que los atuendos tengan un hilo conductor y sobre todo que exista una lógica según la inspiración ya que los diseños deben ser armónicos, no perder su esencia y que todos estén al mismo nivel. 
El delantero y el posterior de estos, deben ser armónicos y complementarse para que el diseño quede perfecto. A estos se le hacen las correcciones pertinentes y se selecciona la mejor chaqueta y el mejor pantalón para que sea el atuendo por confeccionar. Este diseño final es el que mejor representa el punto de inspiración y el que interpreta al máximo este referente.

Como la colección debe constar de chaqueta, pantalón y camisa o camiseta, y ya teniendo ilustrados los pantalones y chaquetas, se procede a la bocetación de camisetas en este caso. Al ser la chaqueta la prenda más recargada, las camisetas diseñadas serán un poco más básicas pero que complementan el atuendo, este proceso de bocetación consta de diez camisetas tanto el delantero como el posterior, innovando en cuello, mangas cortes, texturas y largos.

Con los atuendos listos se llega a la prueba de color, al estudio de color, tendencias, temporadas y ocasiones de uso para hacer el proceso de selección de colores; para llegar a esto hay que tener en cuenta los conceptos mencionados anteriormente (temporada, tendencia), al igual que los textiles a usar.

Jean-Pierre Roy El Pronóstico de denim de WGSN presenta las direcciones clave para ayudarle a planificar sus colecciones de PN 20. Los reportajes sobre nuestras tres tendencias -Secuencia creativa, ¡Es el momento! y TecnoEmociónderivan de los pronósticos de temporada de La Visión de WGSN. (WGSN, 2018)

Teniendo presente esta información, siguiendo una tendencia Secuencia creativa de WGSN para la temporada primavera / verano 2020. "Secuencia creativa explora la fusión entre ciencia, naturaleza y tecnología, que será testigo de cómo el mercado del denim adopta las temáticas del streetwear premium, las líneas depuradas y los tejidos y acabados de influencia tecnológica" (WSGN, 2018). Los puntos de acción de esta tendencia usados en la colección son:

" Adopte un enfoque inteligente hacia la sostenibilidad: Lleve su estrategia sostenible más allá de la cadena de suministro y adopte sistemas circulares completamente integrados.

» Asalte los archivos: Incorpore (sin copiar) las referencias de archivo en sus diseños. Céntrese en la celebración de diseñadores icónicos y en la expresión de la individualidad.

Milhojas: Los términos denim doble o triple no hacen referencia solo a la combinación de una chaqueta y una parte de abajo, sino que abarcan también con- 
ceptos de superposición novedosos e interesantes del diseño y el estilismo. Use unas mangas casquillo en las chaquetas de denim para crear la sensación de estar usando dos capas externas o mezcle las texturas con la combinación de tejidos de nailon brillante para añadir un toque deportivo. La manipulación ingeniosa de las costuras dará como resultado pliegues en niveles u ocultos que crean la ilusión de capas múltiples. Entrega: mediados de primavera y festivales.

Por último, esta tendencia tiene influencias de Prada Sport. Doublet, A\$AP Rocky: Testing, Jean-Pierre Roy, New Order: Get Ready y Palm Angels.

Con la selección de la tendencia, se realiza la paleta de color teniendo en cuenta los centrales, acentos y sobretenidos. Estas pruebas de color se realizan al atuendo escogido para confeccionar en el que exista un balance entre diseño, estructura, accesorios, insumos y color. Teniendo esta investigación se procede a la realización del moodboard de color y tendencia en el que se debe mostrar la paleta escogida y el que debe contar con información gráfica que represente la tendencia de forma clara y que las imágenes transmitan lo que refleja la tendencia.

Al ser una colección con un enfoque jeanswear se maneja, como fibra principal, el denim que puede ser acompañado de otros textiles como driles, panas, gabardinas, sintéticos, linos, terciopelo, entre otros, generando streetwear. En este caso, la colección es jeanswear, con aporte ecológico ya que se utilizó el denim reciclado.

\section{Universo jeanswear}

» Características: unisex, democrático, funcional, versátil

» Fibras: originalmente algodón, hoy mezclado con fibras sintéticas y artificiales

» Bases textiles: denim o índigos pesados entre 14 y 16 onzas

» Silueta: jean (pantalón), cinco bolsillos, complementado por la chaqueta y camisa tipo vaquero

» Color: el azul es proveniente del añil, extraído de la planta de índigo. Diferentes acabados logrados por procesos de lavandería, algunos artesanales o de forma artística

» Ocasiones de uso: múltiples actividades del diario, causal

» Prendas claves: chaqueta tipo vaquero, pantalón, camisa / camiseta 
La bitácora de diseño está conformada por portada y contraportada con diseño referente al punto de inspiración, introducción, o brief, que cuenta el proceso de forma concisa, moodboard de concepto, moodboard de perfil-visionario, moodboard de tendencia, moodboard de materiales (procesos, texturas), diez hojas de los diez atuendos de colección y la bibliografía.

Para el calzado, se hace un estudio de necesidades y beneficios teniendo en cuenta el perfil escogido, en el que se definen aspectos como la ocasión de uso, la tendencia y la temporada sin olvidar el balance que debe tener con el atuendo. El calzado para este semestre se compra, teniendo en cuenta las características anteriores, para que el diseño de este sea el adecuado, e incluso este calzado se puede personalizar si es que se requiere.

El área de diseño trabaja transversalmente con el área de arquitectura, desde la cual se realiza el proceso de confección del atuendo final, teniendo presentes las competencias de patronaje y confección adquiridas a lo largo del semestre y el cual va guiado por el docente quien hace un acompañamiento en la interpretación del diseño, sobre los textiles, y sobre la silueta, construyendo texturas, detalles y todo lo necesario para el que atuendo esté en perfecto estado.

La entrega final tiene varios aspectos a calificar, en primera instancia, el atuendo perfectamente confeccionado que cumpla con todo el proceso realizado y que luzca igual a su ilustración, incluido el calzado; y en segunda instancia el portafolio o bitácora que es el reflejo y el soporte de todo el proceso de desarrollo de la colección con la información respectiva mencionada anteriormente.

\section{Resultados}

Se obtiene una colección masculina para la temporada primavera / verano 2020 del universo casual jeanswear que consta de diez atuendos conformados por chaqueta, pantalón y camisa o camiseta, tanto delantero como posterior.

Cada prenda debe contar con lo siguiente: las chaquetas deben innovar en solapa, mangas, puño, sistema de cierre, bolsillos, además de tener hilo conductor coherencia con el punto de inspiración; los pantalones deben innovar en bota, pretina, bolsillos, sistemas de cierre y tener un hilo conductor; y en cuanto a la camiseta, innovación en cuello, mangas, cortes y largos.

Se selecciona el calzado que vaya acorde a la colección, luego de un análisis de estudio, teniendo en cuenta la ocasión de uso, el perfil y sobre todo el atuendo con el 
que va. En este caso botín con cámara de aire: "Este estilo combina elementos formales y deportivos para crear un nuevo híbrido. Ligera y flexible, la suela con cámara de aire ofrece estabilidad y comodidad" (Bisson, 2018).

De los diez diseños ilustrados, se selecciona el mejor, teniendo en cuenta que este debe contar con los requisitos y la innovación anteriormente mencionada, y debe reflejar el punto de inspiración. Además, debe contar con varios procesos de texturas con las competencias adquiridas desde el área de diseño II, estas se pueden percibir en el atuendo de la siguiente manera: la chaqueta cuenta con alforzas en el posterior, proceso de tintorería y sublimación en posterior, mangas y corte delantero, además de patchwork en diferentes tonos de denim (nuevo y reciclado) organizado en líneas en diferentes direcciones; la camisa cuenta con alforzas tanto en delantero, como en posterior y en mangas; y por último, el pantalón tiene proceso de tintorería en el delantero, con proceso de pintura en corte, el posterior es en patchwork de diferentes tonos de denim (incluido el reciclado) al que se le realiza proceso de desmonte para generar diferentes tonos. Este patchwork está organizado en líneas que van en diferentes direcciones.

Los materiales usados para el atuendo fueron los siguientes: denim en un 80\% (70\% nuevo, diez\% reciclado), ya que el pantalón está confeccionado en su totalidad en denim y la chaqueta cuenta con este material en un 50\% en delantero puños y solapa, además de 50\% de textil con poliéster para la sublimación de diseño. La camisa tiene como base textil algodón licrado en dos tonos.

Se obtiene una bitácora de diseño que, como se mencionó a lo largo del artículo, es un reflejo del proceso de diseño y de elaboración de la colección, es por ello que cuenta con los siguientes parámetros: portada y contraportada con diseño referente al punto de inspiración, introducción, o brief, que cuente el proceso de forma concisa, moodboard de concepto, moodboard de perfil-visionario, moodboard de tendencia, moodboard de materiales (procesos, texturas), diez hojas de los diez atuendos de colección y la bibliografía. Estos son los aspectos más relevantes y los que definen la relación y la semejanza que debe existir entre el punto de inspiración y la colección creada. 


\section{Discusión}

El proceso de construcción de la colección se trabaja transversalmente desde tres áreas: diseño II, en la que se realiza toda la investigación del concepto y del referente a usar, plasmando las ideas en prendas en dibujo plano de manera que sean funcionales y que vayan acorde a la inspiración, tendencia y ocasión de uso. Arquitectura del Vestido II, en la que se realiza la interpretación de las prendas para conocer qué limitaciones hay en cuanto a la confección, qué procesos se pueden realizar desde el área técnica y cuáles no para generar cambios siempre y cuando no alteren la esencia del atuendo y lo que quiere mostrar, esto se plasma primero en el patronaje, para luego confeccionar las prendas. Por último, Ilustración de Moda, en la que se interpretan las prendas a dibujo plano para ser montadas sobre figurín, reflejando las texturas, colores, caídas de las telas, volúmenes y todos los aspectos para que la ilustración vaya acorde con los diseños.

El proceso de diseño tiene varias fases que no se pueden omitir ya que son fundamentales para la obtención de los resultados finales. Es importante recalcar que todas las ideas son válidas en este proceso, siempre y cuando, no se salgan de los parámetros establecidos. Es importante llevar un seguimiento de la inspiración con la actualidad de la moda y sus tendencias para que los resultados de la colección sean acordes a la ocasión de uso y al perfil manejado.

\section{Cuarto, quinto y sexto semestre}

\section{Línea de investigación: diseño e innovación}

El objetivo de la línea es contribuir a los conocimientos y prácticas innovadoras del diseño a través de la producción de conocimiento y el desarrollo de propuestas de proyectos innovadores en el diseño, orientados a responder las necesidades de los contextos sociales y económicos.

\section{Núcleos problémicos}

ergonomía y usabilidad

$»$ producción de artefactos 
Cuarto semestre: diseño de tendencias aplicado al vestuario femenino formal

Núcleo problémico. Ergonomía y usabilidad.

Subtema de investigación. El hiper romántico bohemio

\author{
Palabras clave \\ Espíritu de rebeldía, exaltación a la feminidad, romanticismo.
}

\title{
Objetivo
}

Desarrollar competencias investigativas en los estudiantes de cuarto semestre de Diseño de Modas de la Fundación Universitaria del Área Andina, sede Bogotá, investigando las características del hiper-romanticismo como una experiencia y actitud creativa desde la naturaleza femenina. Experimentando con el diseño de tendencias y la producción industrial de colecciones; sobre el uso de los paños, y con el fin de diseñar una colección en línea femenina para el universo de vestuario formal.

Entregables

» Semana 8

» Artículo de investigación

» Moodboard de concepto

» Bitácora de diseño

» Un indumento con experimentación en técnica de drapeado en paño

» Semana 15

» Portafolio

» Introducción

» Moodboard de concepto

» Macrotendencias/micro tendenciasy su aplicación conceptual (materiales textiles, carta de color, visión y prendas clave) 
» Perfil del consumidor (arquetipo femenino) y evaluación geográfica, psicográfica y demográfica

» Universo del vestuario

» Ocasión del uso

» bitácora de diseño de colección y de diseño de calzado

» Colección de diez diseños femeninos formales para técnica de producción industrial de vestido y chaqueta, en delantero y posterior. 20 ilustraciones en total, análogas y digitales (técnica mixta)

» Dibujos a plano, formato digital

» $\quad$ Patronaje digital de los prototipos en software optitex

» $\quad$ Propuesta de calzado

» Un atuendo femenino formal. Chaqueta estructurada, y vestido o blusa, y pantalón y calzado

\section{Bases textiles}

Paños.

\section{Entregas finales}

Ver figura 16, figura 17, figura 18 y figura 19.

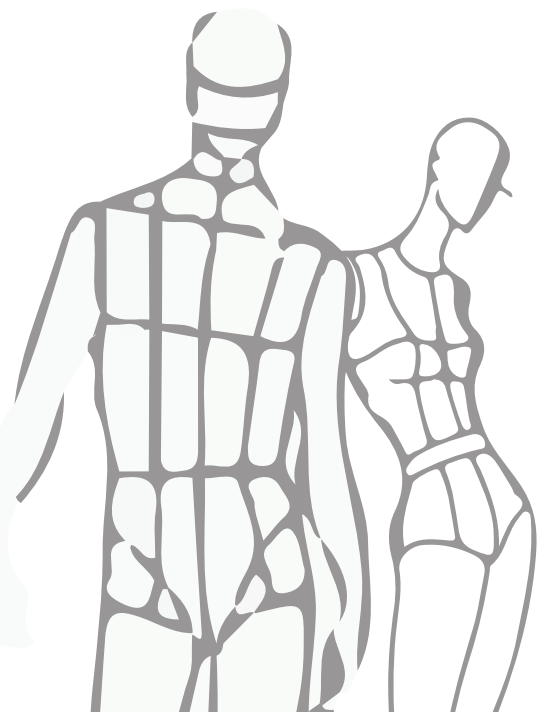




\section{FIGURA 16}

DISEÑO DE TENDENCIAS. FEMENINO FORMAL. CAMILA PERILLA
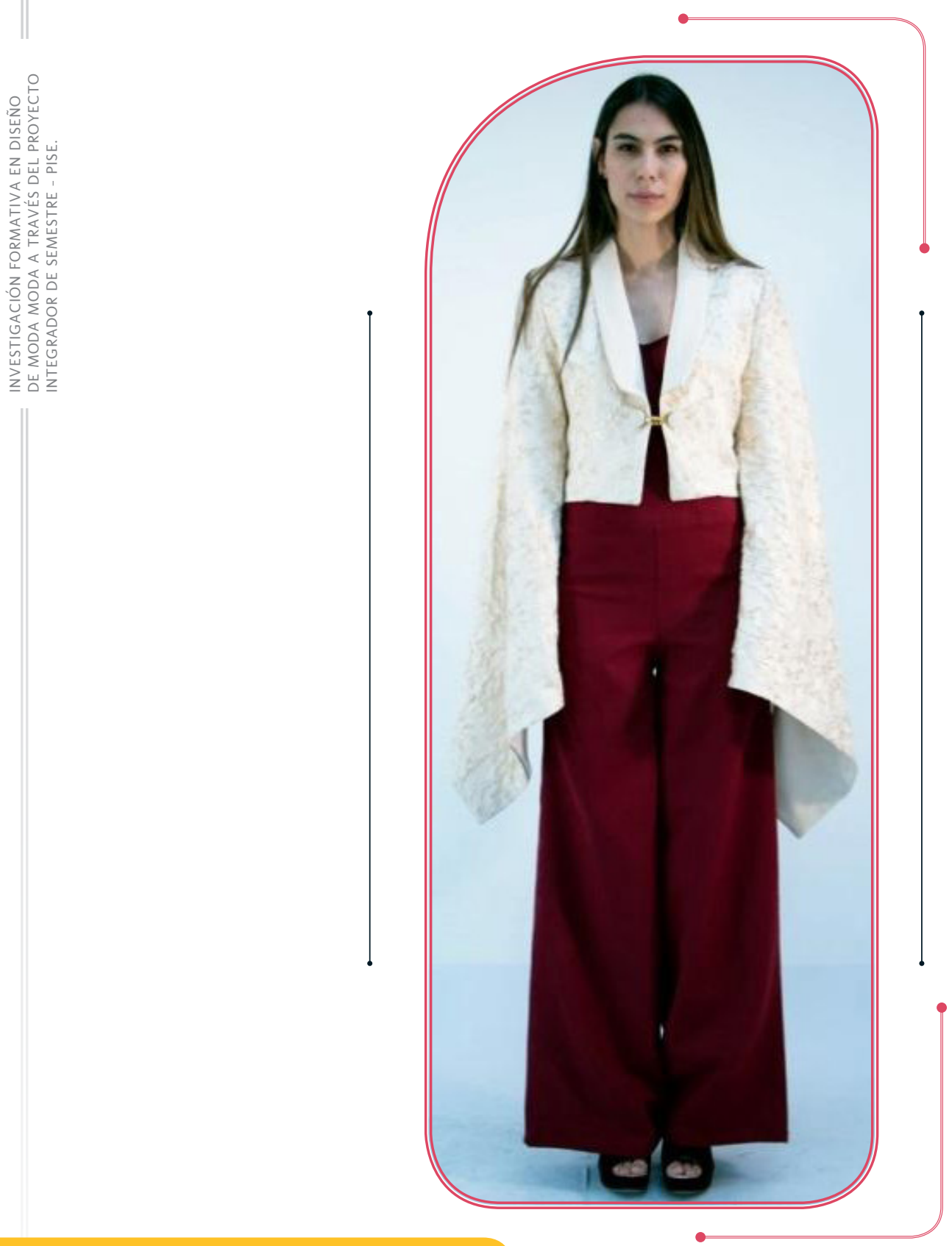

Fuente: Auditorio Fundación Universitaria del Área Andina, sede Bogotá.

Programa de Diseño de Modas León, 2019 


\section{FIGURA 17}

DISEÑO DE TENDENCIAS. FEMENINO FORMAL. MARÍA PAULA TIQUE.

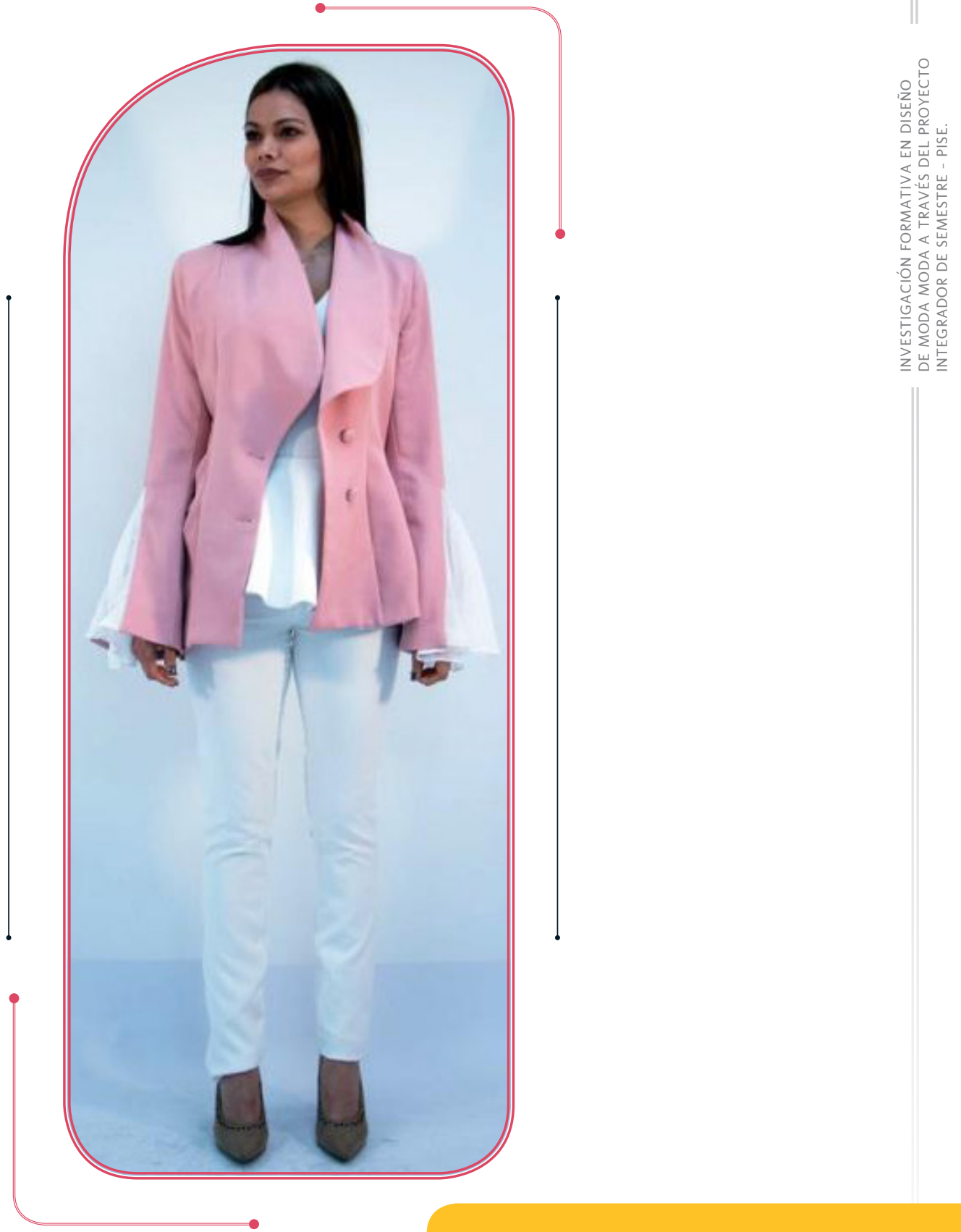

Fuente: Auditorio Fundación Universitaria del Área Andina, sede Bogotá.

Programa de Diseño de Modas León, 2019. 


\section{FIGURA 18}

DISEÑO DE TENDENCIAS. FEMENINO FORMAL. SARA FRANCO.
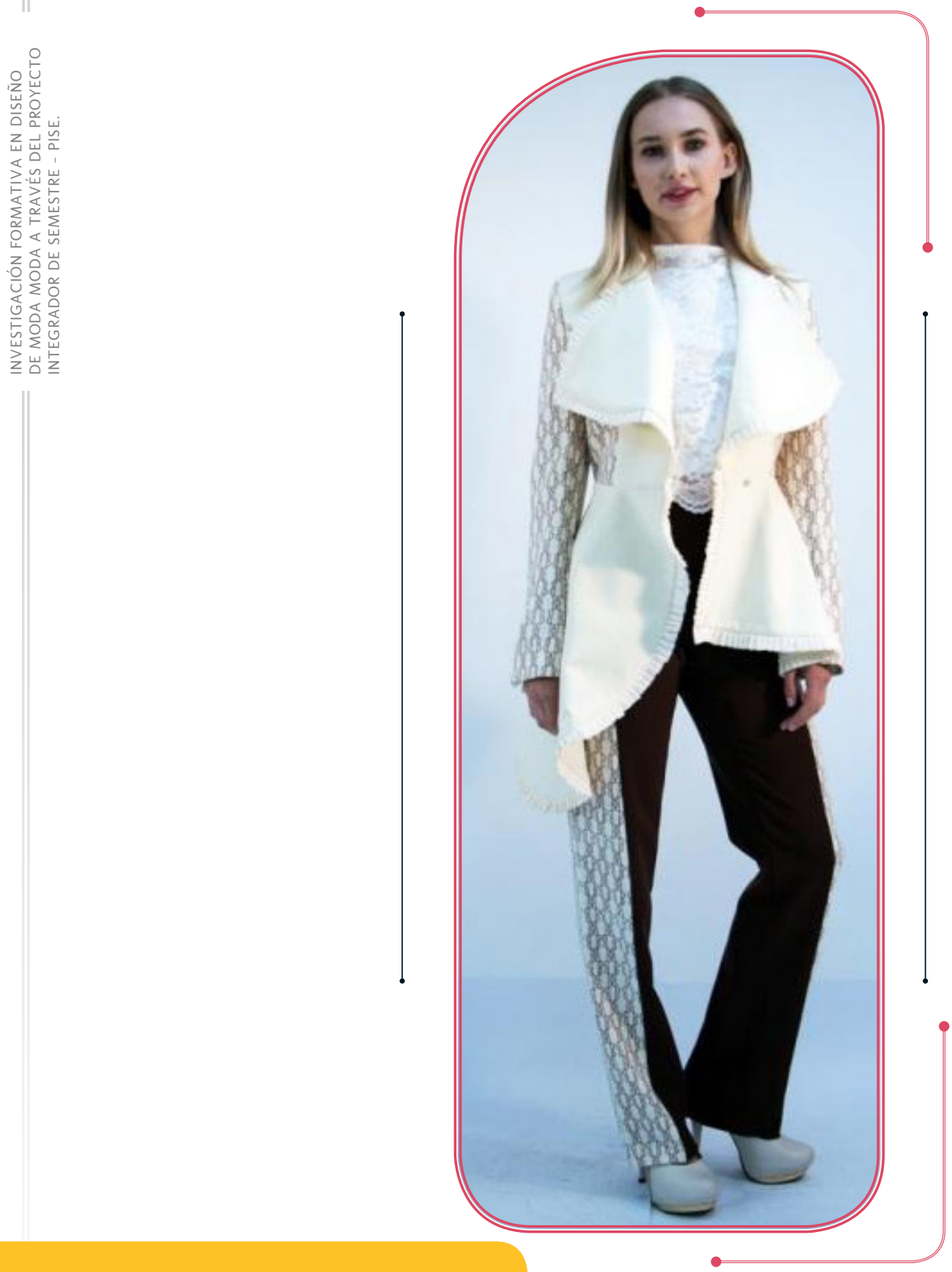

Fuente: Auditorio Fundación Universitaria del Área Andina, sede Bogotá.

Programa de Diseño de Modas León, 2019. 


\section{FIGURA 19}

DISEÑO DE TENDENCIAS. FEMENINO FORMAL. TATIANA RAMÍREZ.

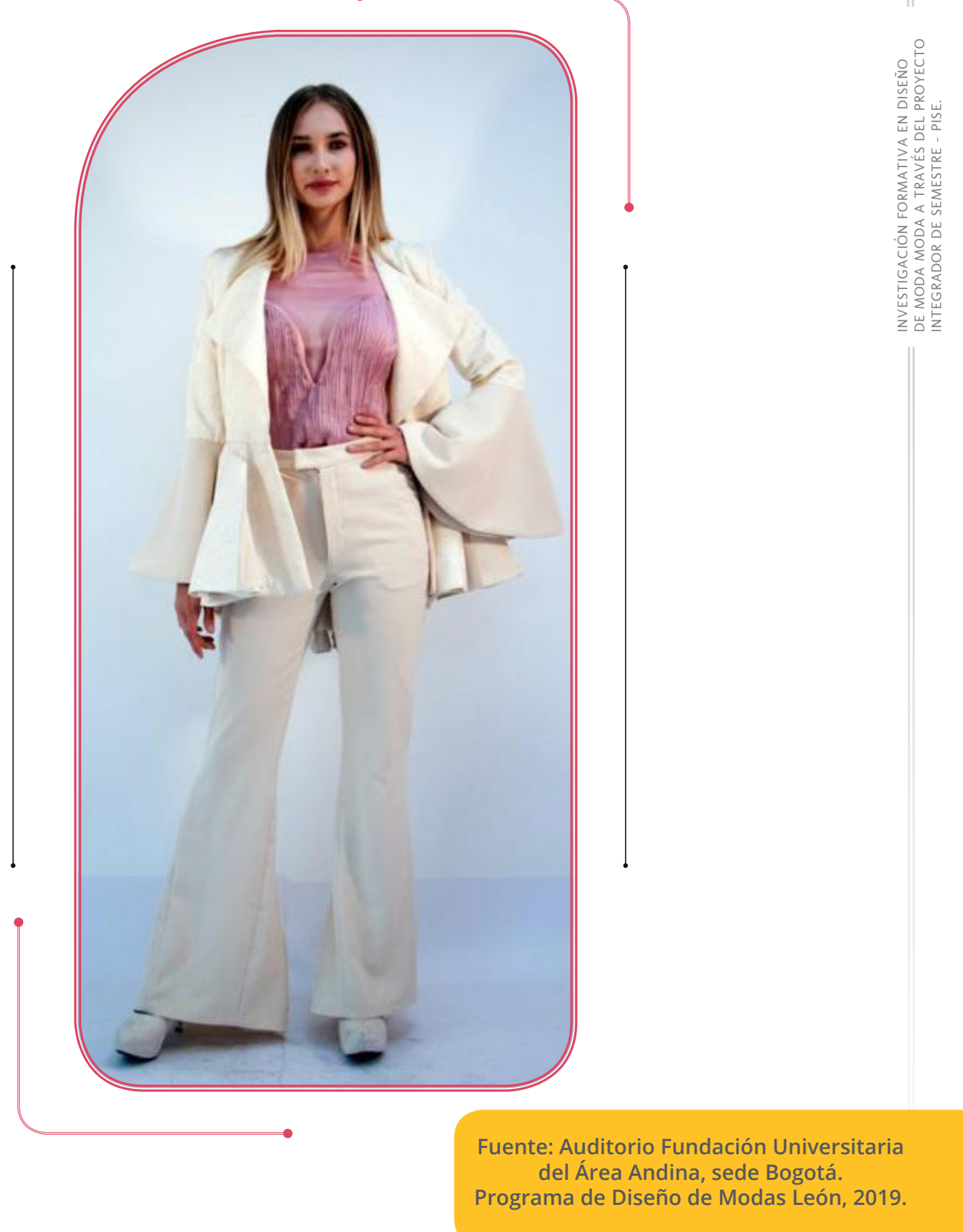




\section{Artículo resultado final: Colección Esencia Liberada. Tatiana Del Pilar Ramírez Marín}

\section{Resumen}

Esencia Liberada tiene una trayectoria de elaboración, como punto de partida. La historia del traje nos da un gran abrebocas y una gran visión de lo que es la sastrería femenina como pauta clave para el desarrollo del diseño. La historia del traje en el siglo xviii refleja características específicas del movimiento ideológico de la época y ofrece todo un bagaje de conocimiento para la aplicación del mismo, entendiendo qué materiales son adecuados, el significado de los tipos de atuendos y con esto se logra transmitir la importancia de cada prenda, y cuál debe ser su uso.

El romanticismo, como tema general y punto de partida, logra vislumbrar grandes posibilidades, donde encontramos que el tema principal es el sentimiento puro, de donde surge el expresionismo debido a la época de la ilustración en la cual hay una ruptura de lo ya establecido dentro del régimen europeo. La literatura romántica expresa la naturalidad, la belleza, la libertad del alma y estos son factores esenciales de la colección, que están fundidos en telas, colores, texturas y volados. A continuación, en el artículo, veremos, detalladamente, cómo se desenvuelve la historia del traje, sus usos y descripciones, el proceso de investigación paso a paso, los siete estadios, qué es la metodología de diseño que se usó para el desarrollo general de la colección que se centra en el perfil de consumidor, punto de inspiración, paleta de color, texturas aplicables, que ayudan a ser el polo a tierra de la colección. Estos paneles logran dar una guía específica como hilo conductor para llegar al proceso de bocetación, en el cual se plantean en figurines ya como tal los diseños. Este proceso de principio a fin ha sido muy enriquecedor. A continuación en el texto principal se hará un recuento detallado de cada proceso.

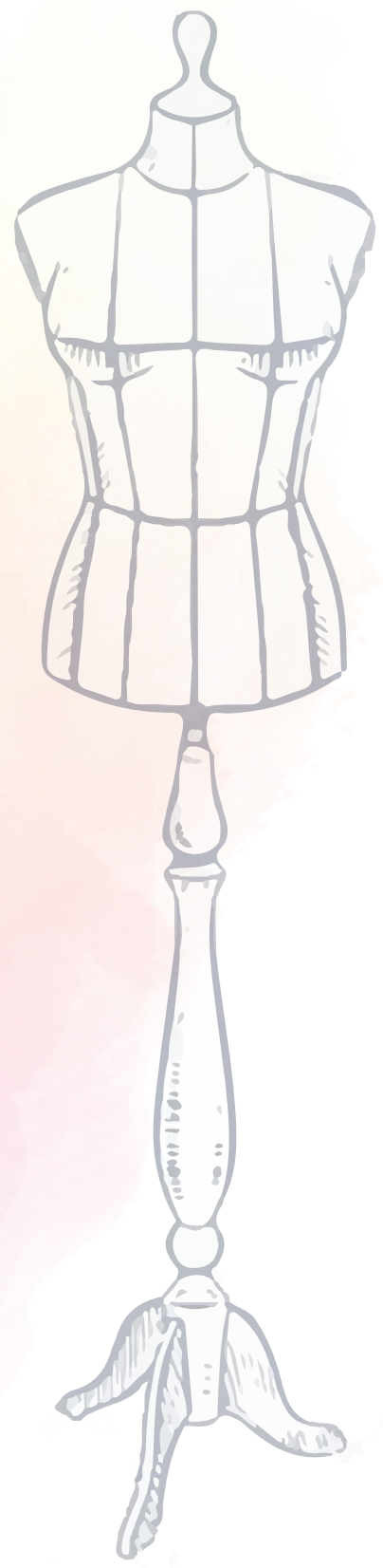




\section{Introducción}

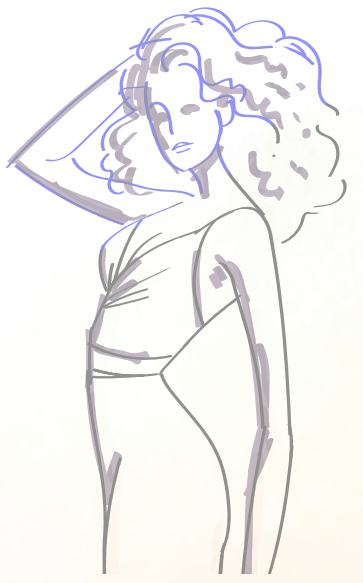

Dentro del articulo veremos a detalle el proceso de elaboración de la colección Esencia Liberada donde muestro la importancia de cada parte del proceso donde resalto el tema principal que es la poesía romántica como punto de inspiración que nos llevará a encontrarnos con la naturaleza como refugio para el alma; de allí se abre un gran panorama de conceptos, colores, formas siluetas que logro obtener e imprimir en bocetos, de allí veremos la magia que se desata en el proceso de construcción y como consecuencia de esto el atuendo final.

\section{Método}

Siete estadios clave, es la metodología planteada en el libro Directorio de formas y estilo (Travers-Spenser, et al., 2008) donde se presentan ciertos pasos que guían al diseño y elaboración de vestuario, el cual permite contemplar todos los puntos clave de enfoque que logran transmitir con efectividad y claridad lo que el diseñador quiere expresar.

Como primera instancia, la investigación es el origen de las ideas, y como tema específico y punto de inspiración, el programa de Diseño de Modas propone el movimiento cultural bohemio, dado en el siglo xix, y el romanticismo, siglo xviii. El movimiento bohemio nace en el barrio latino parisino de la Francia del II Imperio. Este movimiento tiene como principal objetivo dar una nueva alternativa frente al tipo de arte que presentaban los burgueses, dejando de lado la imposición de lo que debería ser bello, lo correcto, etc. Había poca sensibilidad por el arte, era un arte frío, fácil, donde el materialismo, el lujo invaden la sociedad. Este movimiento busca la libertad, la independencia y un sentido antiburgués.

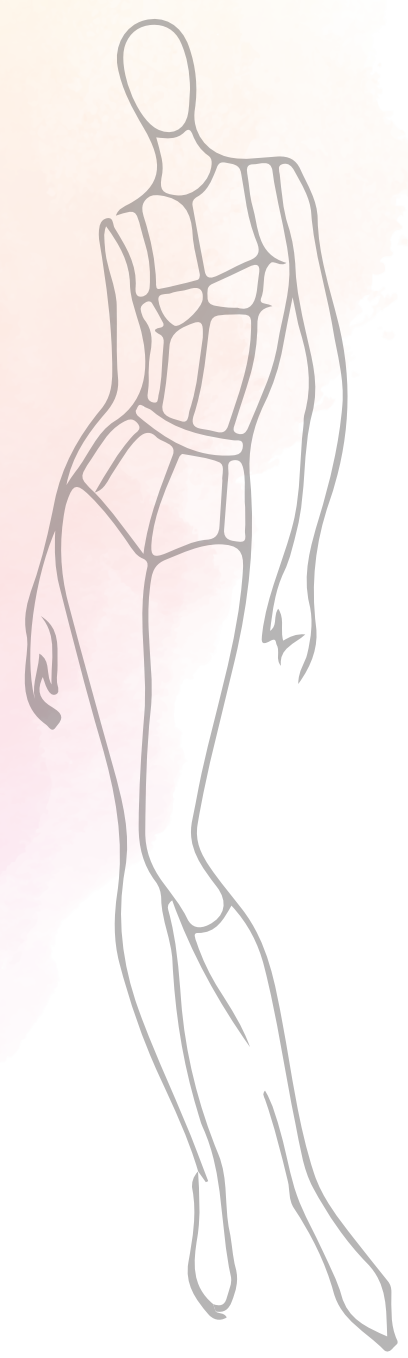


En cuanto al romanticismo, fue un movimiento artístico enfocado en la literatura, la música y en las bellas artes, que se rebeló contra el racionalismo de la ilustración, el siglo de las luces y los cánones de belleza establecidos.

El término romántico, es lo opuesto a la razón, es lo que no se puede argumentar desde la razón. Va de la mano con los sentimientos, es lo opuesto a lo clásico, se enfoca en el subjetivismo. Dirige la mirada al sujeto individual, medita en su existencia frente a la muerte y se enfoca en el sentimiento puro del ser. En cuanto a la literatura romántica, su base filosófica era el idealismo, que está de acuerdo con una perfección ideal, a un modelo de armónico, el culto al yo y a la idealización de la naturaleza.

FIGURA 20

MOODBOARD DE DISEÑO.

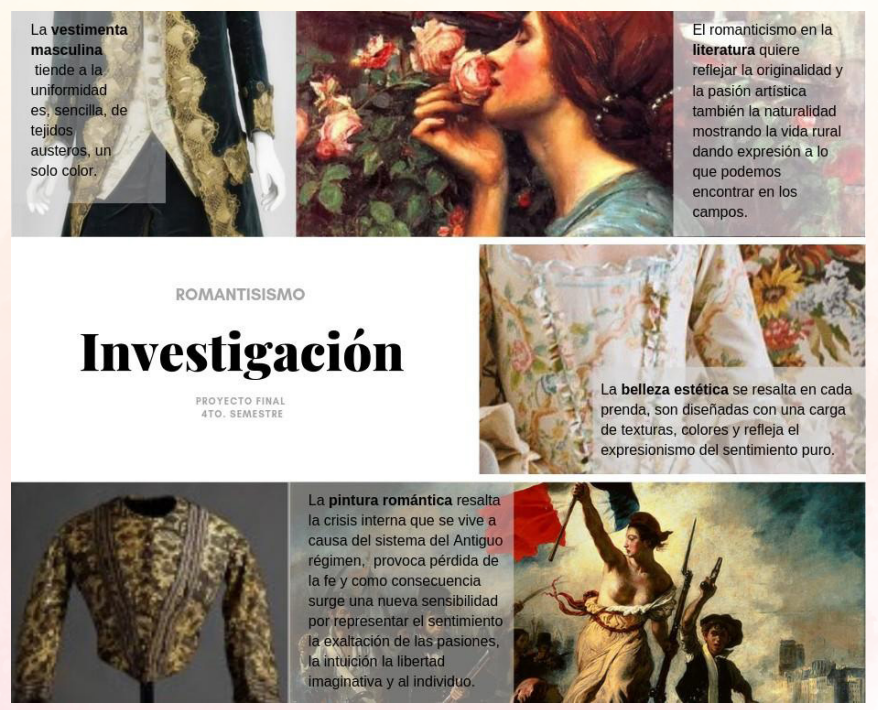

Fuente: Tatiana Del Pilar Ramírez Marín.

La literatura romántica revalora la naturaleza, donde surge una preocupación por ella, busca el placer que da los lugares intactos, donde se encuentra un refugio para el alma, y es allí donde la pasión artística y la originalidad surge (Daürr, 1983).

Mi colección está inspirada en la poesía. A continuación, presento una muestra de lo que fue la poesía en la época, en el poema Rima LIII de Gustavo Adolfo Bécquer:

Volverán las oscuras golondrinas

en tu balcón sus nidos a colgar, y otra vez con el ala a sus cristales jugando llamarán. 
Pero aquellas que el vuelo refrenaban

tu hermosura y mi dicha a contemplar, aquellas que aprendieron nuestros nombres...

¡esas... no volverán!

Volverán las tupidas madreselvas

de tu jardín las tapias a escalar,

y otra vez a la tarde aún más hermosas

sus flores se abrirán.

Pero aquellas, cuajadas de rocío

cuyas gotas mirábamos temblar

y caer como lágrimas del día...

¡esas... no volverán!

Volverán del amor en tus oídos

las palabras ardientes a sonar

tu corazón de su profundo sueño

tal vez despertará.

Pero mudo y absorto y de rodillas

como se adora a Dios ante su altar,

como yo te he querido...; desengáñate,

iasí... no te querrán. (Psicología y Mente s.f.)

El autor resalta la naturaleza como factor de inspiración, y así compara su amor con la intensidad, la grandeza y delicadeza que transmite la naturaleza. Menciona las flores y la lluvia, y las toma como refugio para su alma.

Con esto en mente, podemos empezar a buscar referentes de productos que se asemejan a lo que he contemplado como proyecto final. Con ello puedo desarrollar el panel de producto en el cual busco la versatilidad, resaltar la libertad, originalidad y lo más importante, resaltar al individuo que lo porta. El panel de producto muestra el tipo de prendas que quiero lograr en cuanto textura color, movimiento manteniendo la sobriedad. Es un producto que logra impactar en un ambiente de elegancia, inspirando imponencia sin necesidad de sobrecargar el atuendo con demasiados elementos.

El perfil, o cliente, que usará este atuendo es una mujer de 25 a 33 años. Una mujer que es segura de sí misma y logra encontrarse a ella misma logrando ver su belleza única. Mi perfil de usuario es contemporáneo, está a la vanguardia y logra versatilidad debido a su dinamismo, ya que adoptará nuevas tendencias que le permitirá estar en evolución. Su vida siempre es activa, el confort y la armonía son conceptos claves que no pueden faltar a la hora de vestirse, su enfoque de vida se centra en el desempeño profesional. En sus tiempos libres busca lugares que le permitan experimentar nuevas sensaciones. 


\section{Paleta de color}

Como primera instancia busqué colores correspondientes al romanticismo. Colores como crema, dorados palo de rosa. Colores contrastantes como el rojo, verde azulado, entre otros, pero dentro del proceso de la asignatura llegamos a un acuerdo para unificar la colección grupal. De esta paleta se escogieron dos colores fundamentales con tres tipos de textiles (figura 21).

\section{FIGURA 21}

PALETA DE COLOR ACORDADA EN LA ASIGNATURA DE DISEÑO Y MOODBOARD TEXTIL Y DE COLOR.
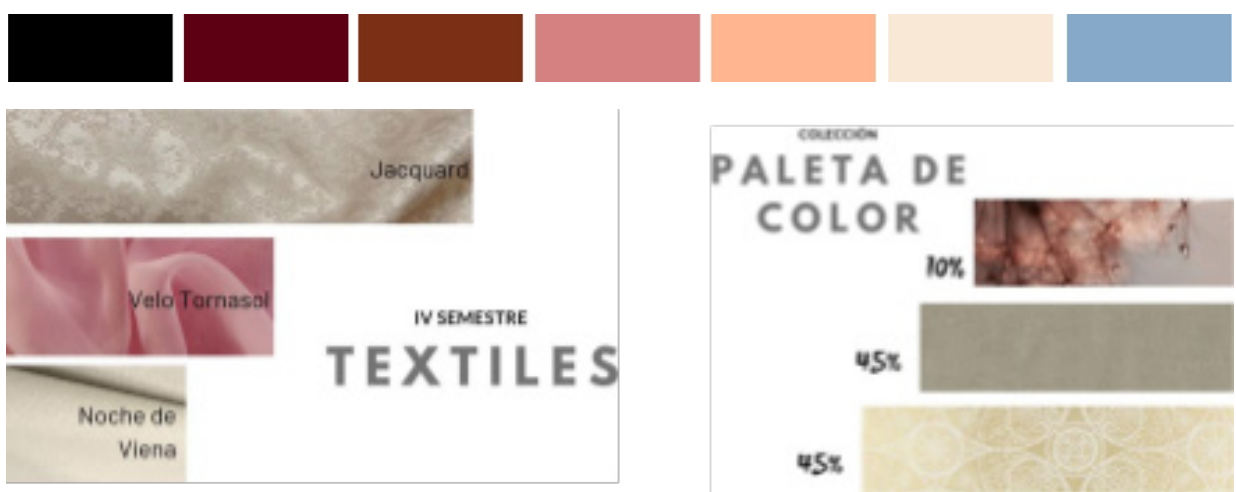

Fuente: Tatiana Del Pilar Ramírez Marín.

Los porcentajes se han asignado de esa manera para darle elegancia al atuendo sin quitarle importancia a las prendas de menos porcentaje.

El atuendo está compuesto por cuatro piezas que son: pantalón con bota semi ancha con texturas troqueladas, combinación de textiles; corsé con base de piel de ángel y plisado cristal de $5 \mathrm{~mm}$ de ancho; blusa básica en velo tornasol y la chaqueta está hecha en jacquard, tiene incluida una falda en godet.

El color crema y palo de rosa hablan de esa tranquilidad que nos genera la naturaleza al contemplarla y al sumergirnos en ella, evoca imponencia, desenvolvimiento libre en su entorno, que resalta la delicadeza de la mujer y su espontaneidad. Las formas que se generan en el atuendo son formas orgánicas. Son formas libres que son notorias en la parte inferior de la chaqueta, en las mangas y en la bota del pantalón. En cuanto a las técnicas de comunicación visual encontraremos sutileza, acento en el movimiento que genera la parte inferior de la chaqueta, hay transparencia que 
refleja la osadía y el empoderamiento de una mujer que no teme, si no que enfrenta sus retos, hay una coherencia en cada prenda que acompaña al atuendo. En cuanto la interrelación de formas encontraremos que hay una superposición en la parte inferior de la chaqueta generando nuevas formas, también veremos gradación.

El proceso para llegar al equilibrio, en cuanto a la forma, color y textura, fue un camino largo en el cual tuve que hacer bastantes bocetos, cambiar y variar algunos, ya que al hacer los primeros bocetos me di cuenta de que estaban muy simples y entendía que debía generar un impacto visual. También los anchos y largos de las prendas básicas fue algo limitador ya que una de las condiciones era usar solo dos siluetas. A la hora de diseñar me encuentro con tantas posibilidades para aplicar los conceptos, que a veces me sucede que recargo el atuendo, así que tuve que hacerles varias modificaciones a los bocetos hasta lograr un equilibrio y un mismo hilo conductor en toda la colección.

\section{FIGURA 22}

ILUSTRACIÓN DE LA COLECCIÓN.

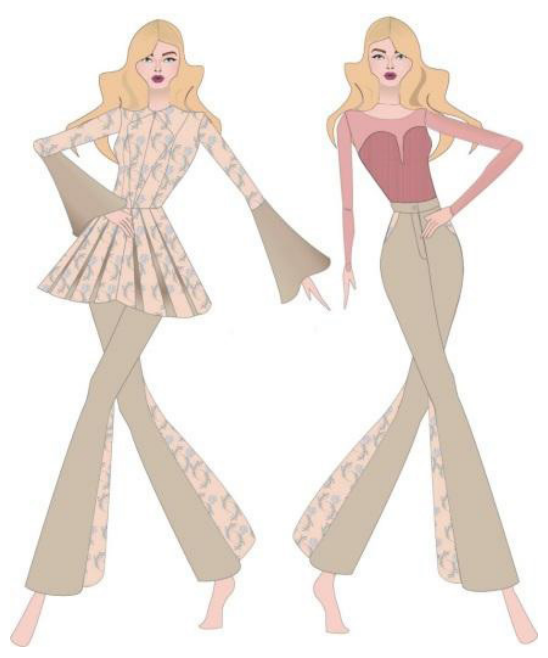

Fuente: Tatiana Del Pilar Ramírez Marín.

Mis referentes principales son Coco Chanel y Kika Vargas. Chanel, por su parte tiene atuendos muy contundentes, donde su esencia es la comodidad y la elegancia, entregándole al usuario empoderamiento, un estilo muy marcado y el reconocimiento directo de la diseñadora, uno de sus lemas era el "lujo sencillo" donde menos, es más. Una frase que ella mencionaba que cabe resaltar es "Antes de salir de casa una mujer debería siempre mirarse al espejo y quitarse uno de los complementos" Coco Chanel (Iglesias, s.f.). 
En la asignatura de diseño vimos como referente a Coco Chanel para sastrería femenina, centrándonos en primavera / verano. A continuación, presento algunos atuendos que logran cautivarme y por ello puedo decir que han sido referentes para el diseño de mi colección.

\section{FIGURA 23}

HAUTE COUTURE PRINTEMPS - ÉTÉ 2019 - PRÊT-À - PORTER AUTOMNE - HIVER 2019
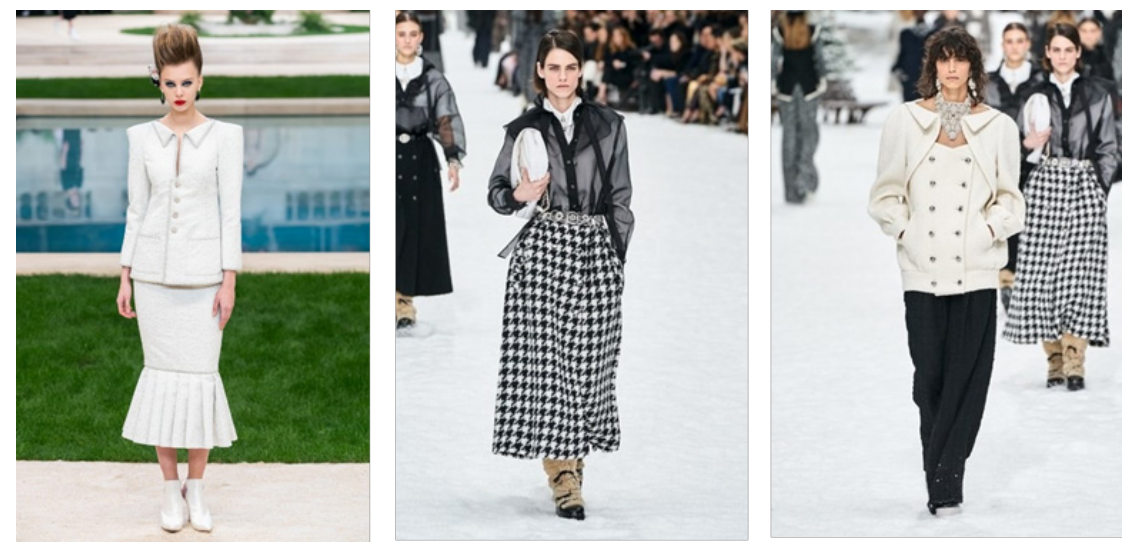

Fuente: Perier.

En cuanto a Kika Vargas, es una diseñadora colombiana muy completa. Resalto su osadía, su insistencia en lo que cree, a ella se le puede atribuir la rebeldía como cualidad ya que desafía lo establecido y se aleja de lo sospechado. Su exploración en formas, volúmenes estampados y diferenciación en las siluetas, es el plus que la ha llevado a vestir figuras púbicas por ello es inspiración para mi colección. (Villamil).

\section{FIGURA 24}

DISEÑOS DE KIKA VARGAS.
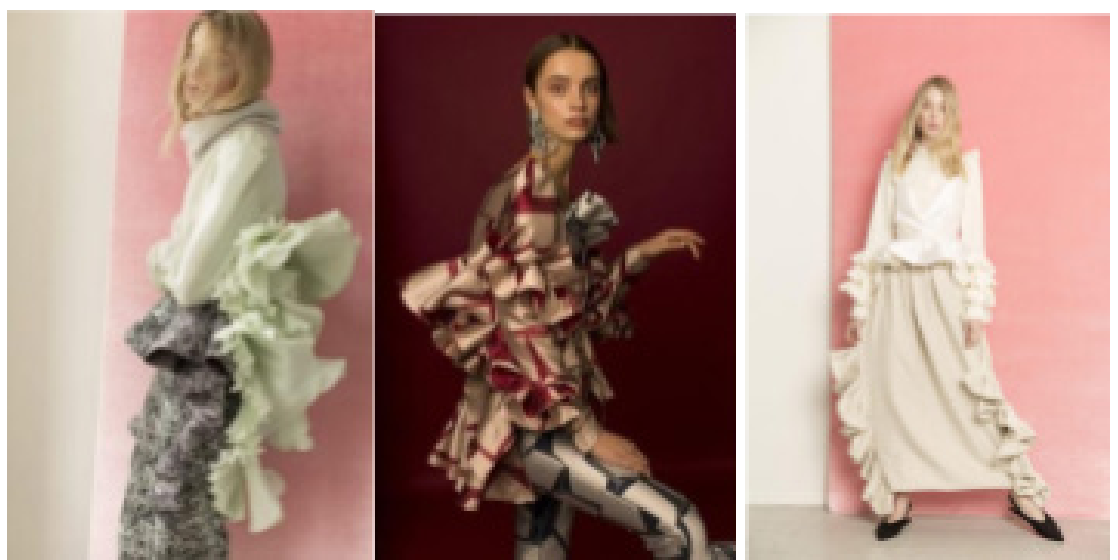
Kika Vargas logra resaltar la belleza de la mujer impactando con textiles diferentes, velos chifones, telas tornasoladas, texturas como plisados, golas, mangas con grandes volúmenes y demás.

\section{Conclusiones}

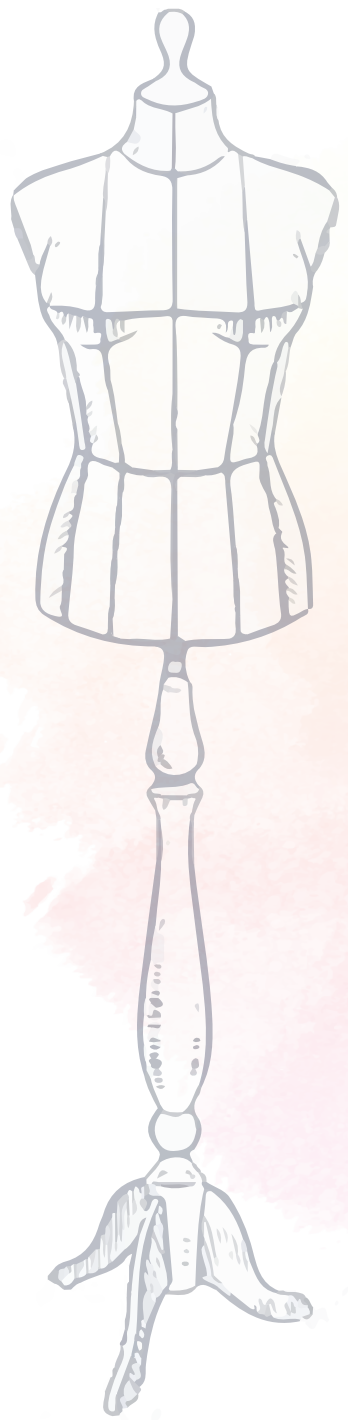

En cuanto al proceso de diseño que he venido detallando y analizando, puedo concluir que está claro que es necesario conocer el punto de partida, en este caso el tema principal como proceso de investigación para tener claro los conceptos, aun no solamente esto, también se debe tener claro, el cómo hacerlo, el cuándo, con qué recursos se cuentan y como se han de utilizar, que riesgos se pueden evitar, el tiempo y la dedicación son factores claves para desarrollar el proceso con la puntualidad que se requiere, que colores son los aptos para cada temporada, que textiles son aptos y que siluetas son las más convenientes, he entendido que menos es más gracias a nuestros referentes de base, que son grandes influenciadores en mi carrera, he aprendido mucho de este proyecto.

Este proyecto fue bastante significativo para mí como diseñadora porque he adquirido conocimientos que me enriquecen. Ver este atuendo, desde un boceto a lápiz hasta verlo construido, es un gran paso que requiere entrega, fuerza, osadía, disciplina y amor por el diseño. Mis más grandes agradecimientos a cada docente que estuvo involucrado en este proceso de crecimiento, a la facultad y a la directora del programa Ivonne Riachi. 
Quinto semestre: diseño de moda nacional aplicado a la sastrería masculina

\title{
[T3]Núcleo problémico. Ergonomía y Usabilidad
}

Subtema de investigación. Retro sesentas, setentas y ochentas.

\author{
Palabras clave \\ Fusión, geek, nostalgia a la época, protagonismo del color y de la imagen.
}

\section{Objetivo}

Desarrollar competencias investigativas en los estudiantes de quinto semestre de Diseño de Modas en la Fundación Universitaria del Área Andina, sede Bogotá, investigando sobre las décadas de los sesenta, setenta y ochenta, y las influencias culturales que marcaron la historia- Experimentando con el funcionamiento, los clústers de la moda nacional y la producción industrial de colecciones, con el fin de diseñar una colección en línea masculina para el universo de vestuario formal.

\section{Entregables}

» Semana 6

» Artículo de investigación

» Moodboard de concepto

» Bitácora de diseño

» Un chaleco masculino formal en paño 100\%.

» Semana 15

» Portafolio

» Introducción

» Moodboard de concepto

» Macrotendencias / micro tendencias y su aplicación conceptual (materiales textiles, carta de color, visión y prendas clave). 
» $\quad$ Perfil de del consumidor (arquetipo masculino y perfiles emergentes) y evaluación geográfica, psicográfica y demográfica

» Universo del vestuario.

» Ocasión de uso

» Colección de diez diseños, masculinos formales, para técnica de producción industrial de sastrería; en delantero y posterior. 20 ilustraciones en total, digitales.

» Dibujos a plano (colección completa), formato digital.

» $\quad$ Patronaje digital de los prototipos en software gerber

» $\quad$ Propuesta de calzado.

» Semana 16

» Página web (WIX).

» Un indumento masculino formal, compuesto por tres prendas: camisa, pantalón y saco. Calzado.

\section{Bases textiles}

Algodones camiseros, paños livianos y pesados, terciopelos, gobelinos, jacquard y lino.

\section{Entregas finales}

Ver figuras de la 25 a la29. 


\section{FIGURA 25}

DISEÑO NACIONAL. SASTRERÍA MASCULINA. LAURA SÁNCHEZ
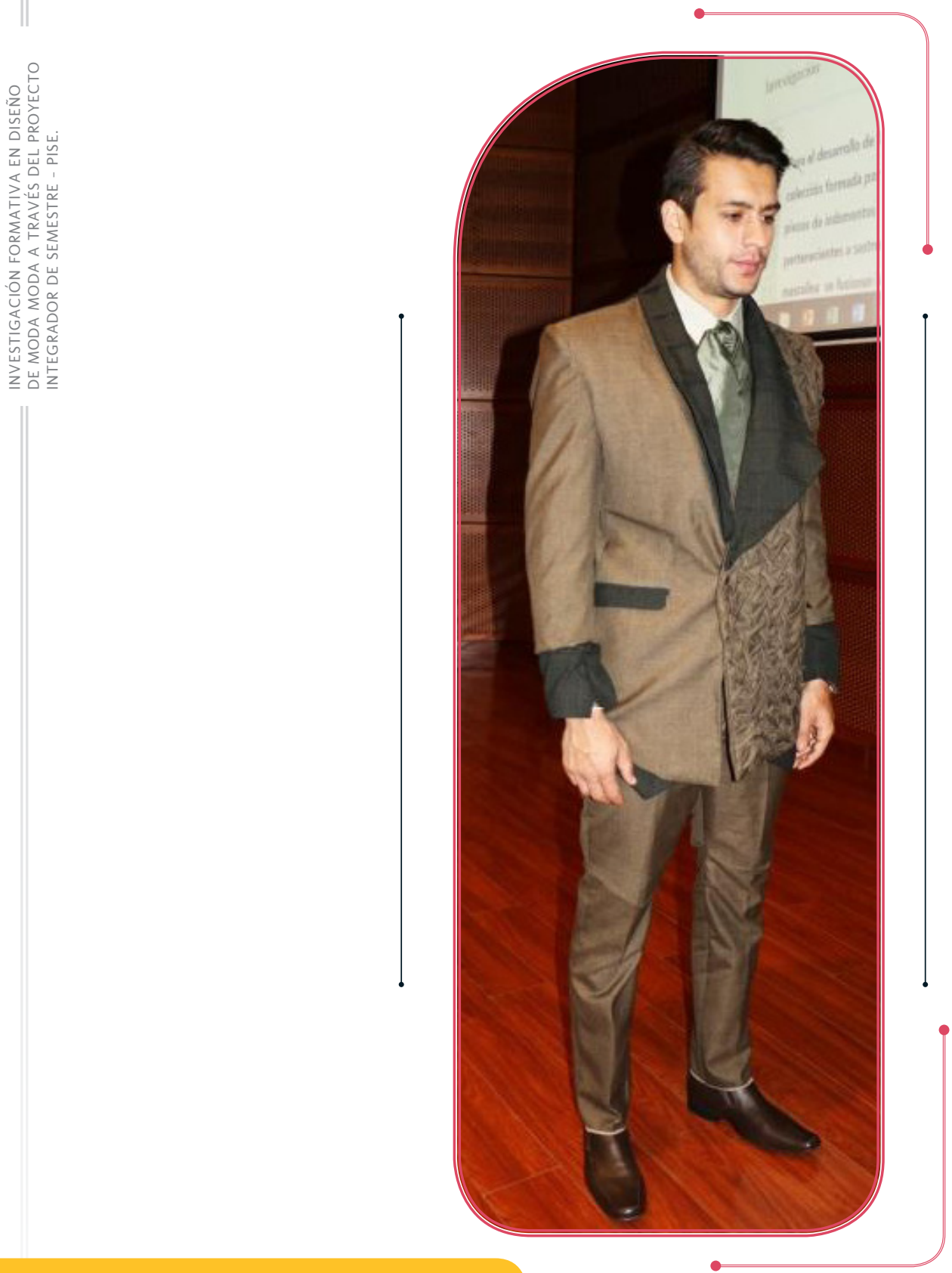

Fuente: Auditorio Fundación Universitaria del Área Andina, sede Bogotá.

Programa de Diseño de Modas Riachi, 2019. 


\section{FIGURA 26}

DISEÑO NACIONAL. SASTRERÍA MASCULINA. DANIELA INFANTE.

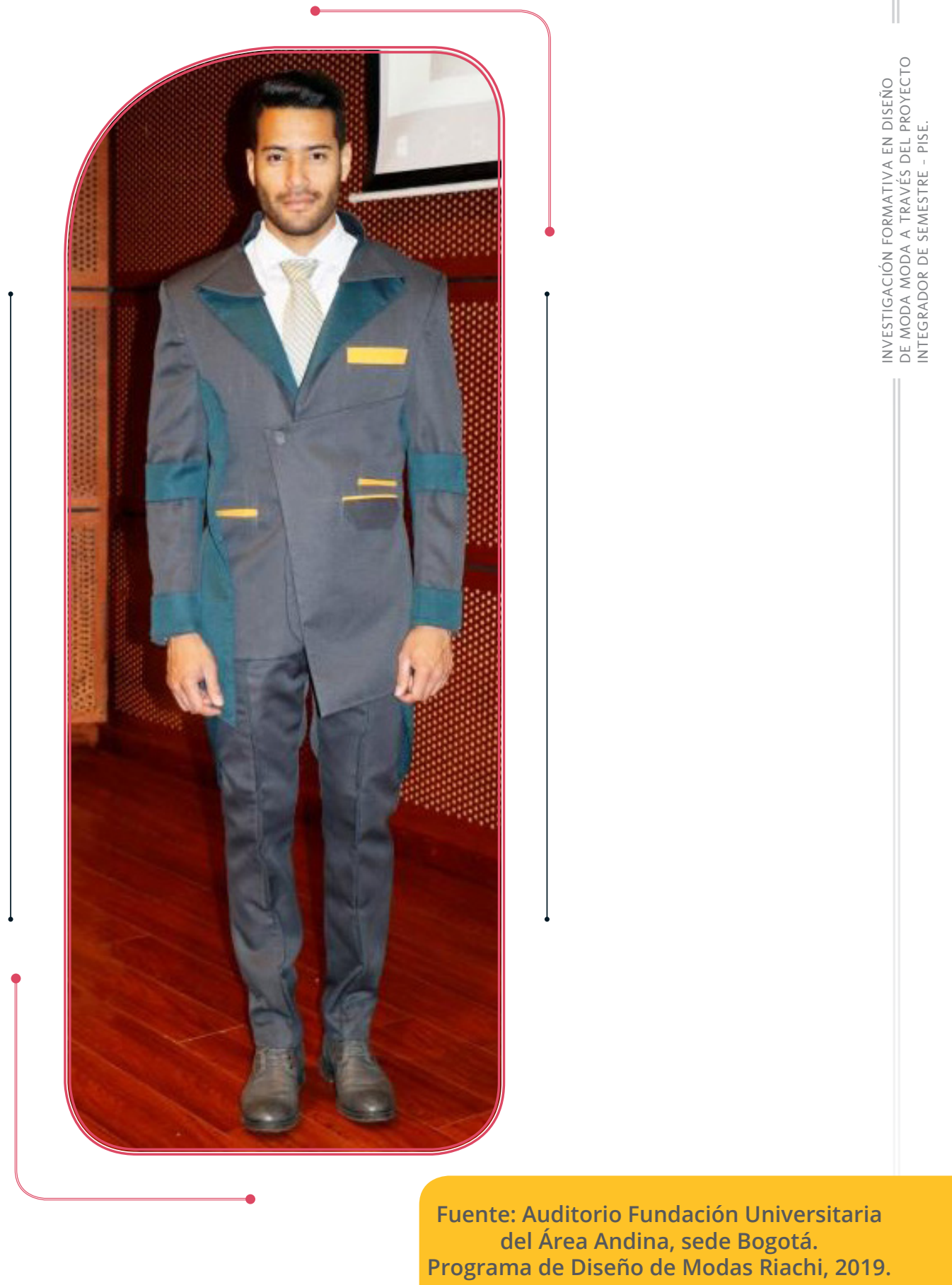




\section{FIGURA 27}

DISEÑO NACIONAL. SASTRERÍA MASCULINA. VIVIANA VELÁSQUEZ.
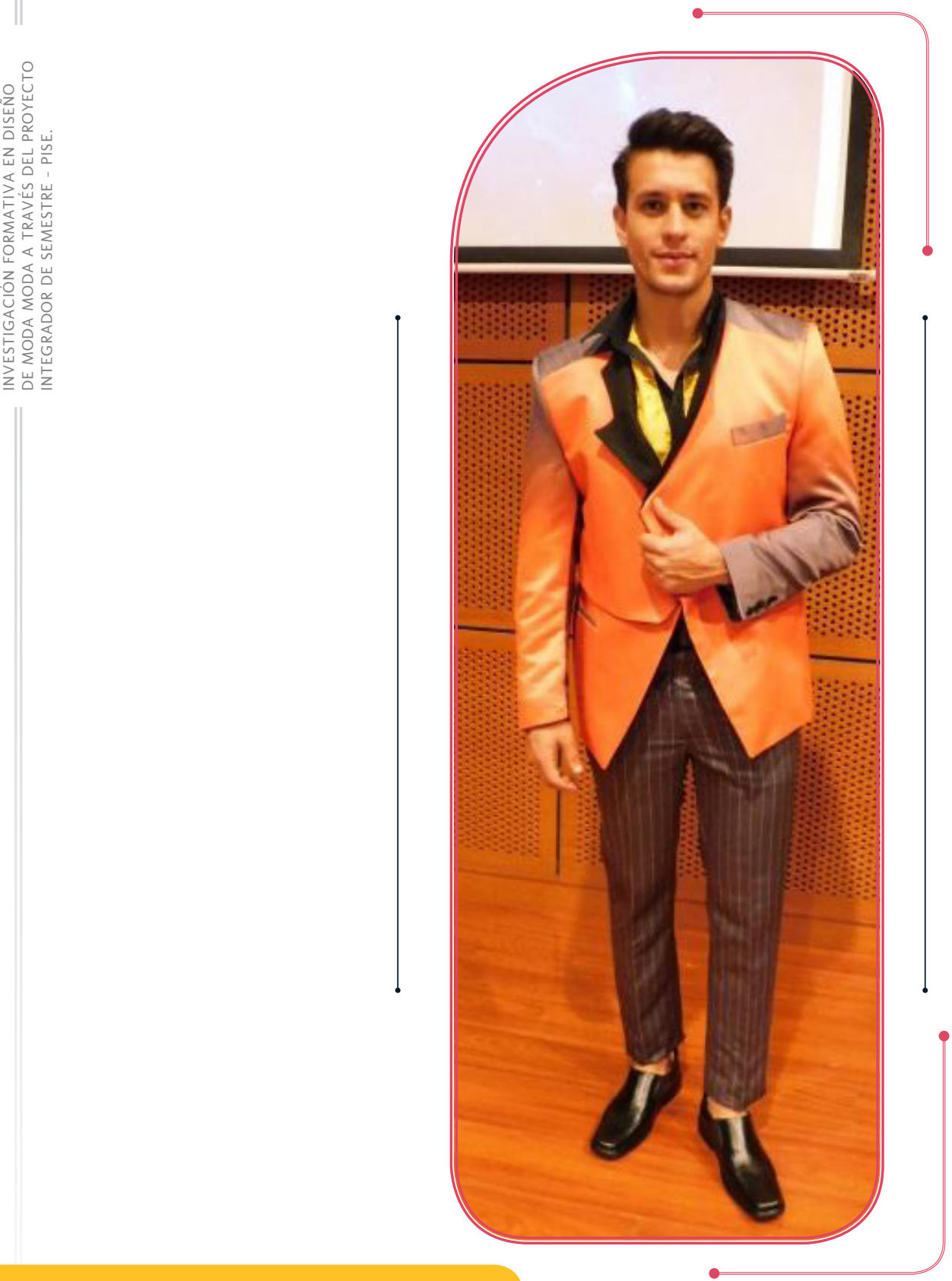

Fuente: Auditorio Fundación Universitaria del Área Andina, sede Bogotá.

Programa de Diseño de Modas Riachi, 2019. 


\section{FIGURA 28}

DISEÑO NACIONAL. SASTRERÍA MASCULINA. JOHANNA FORERO.

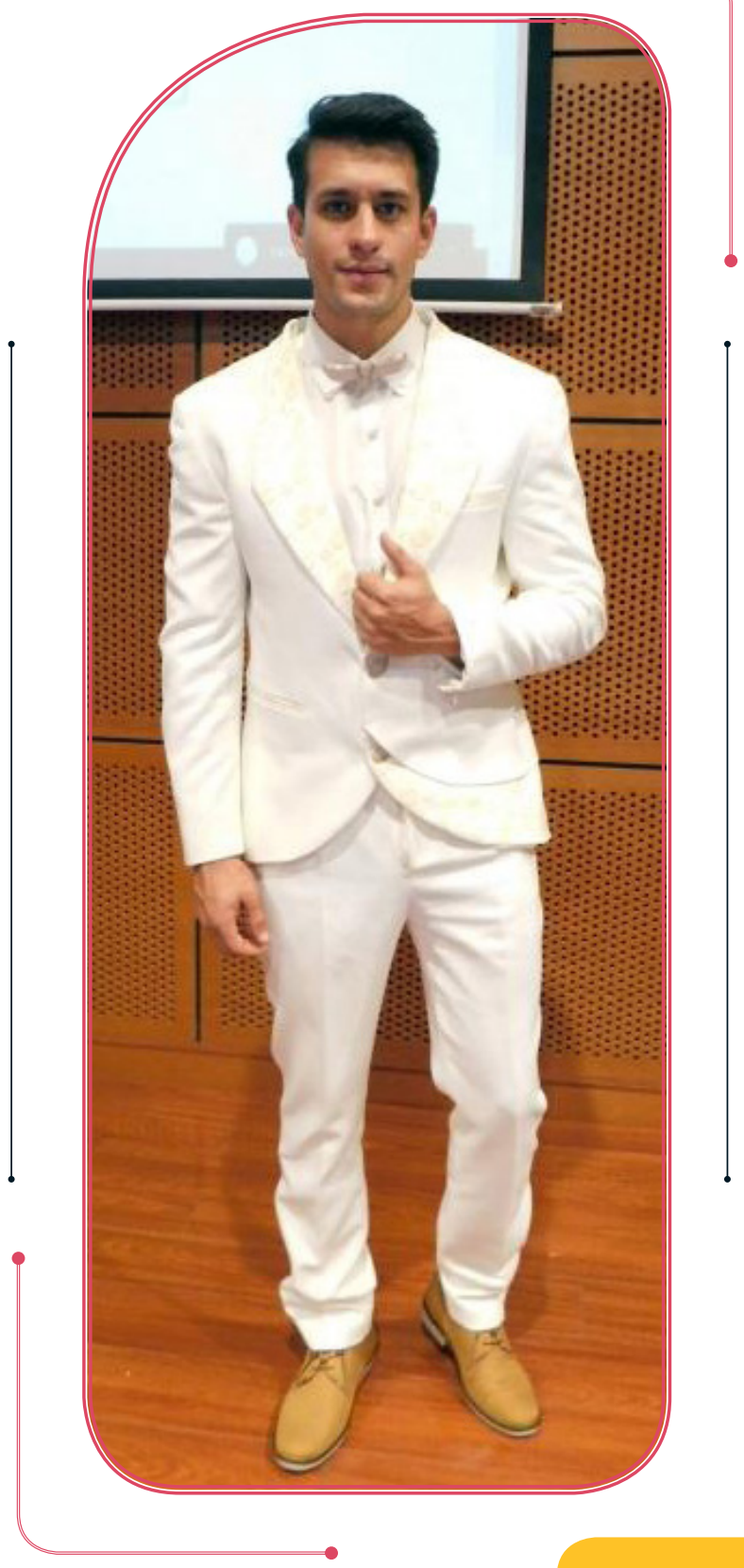




\section{FIGURA 18}

DISEÑO NACIONAL. SASTRERÍA MASCULINA. STEFANY VARGAS.
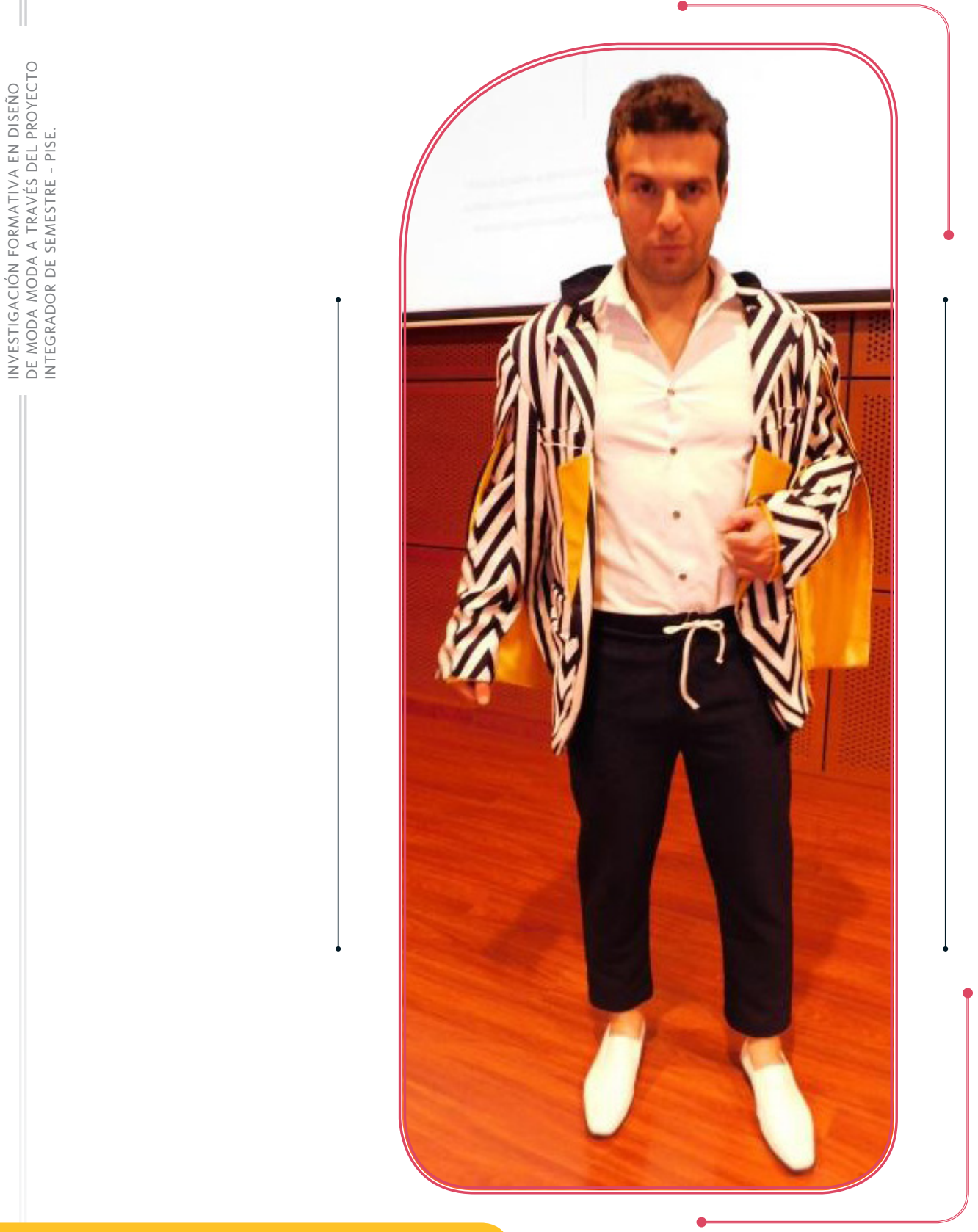

Fuente: Auditorio Fundación Universitaria del Área Andina, sede Bogotá.

Programa de Diseño de Modas Riachi, 2019. 


\section{Artículo resultado final: Los sesenta, tendencia en revolución: los estampados, los peinados y el color. Katherine Viviana Miranda Ayala}

\section{Resumen}

El planteamiento de una temática directamente relacionada con la temporalidad, el contexto y las situaciones bajo las cuales se desarrolló, demanda una investigación amplia y clara sobre las condiciones y las motivaciones de distintas acciones dentro del ámbito de la moda. Los años sesenta estuvieron marcados por acontecimientos cruciales para los colectivos revolucionarios y reclamadores del cumplimiento de los derechos y de las obligaciones del estado, la moda fue un grito, una forma de revelarse ante años de represión y sometimiento, la moda fue a penas un paso inicial que abrió este gran lapso de tiempo, reconocido hoy en muchos lugares, como icónico. Las muestras poblacionales, los apartados que registran la cantidad de percepciones encontradas alrededor del tema y los hechos constatados por artículos que comprueban con veracidad lo que sucedió, son el respaldo para la sustentación de la temática.

Se pone en evidencia, entonces, la carga histórica y crucial de esta época, sus principales exponentes en cada uno de los géneros correspondientes a las artes y lo que se generó a partir de esto, un paralelo comparativo, un antes un después. "Los 60's, tendencia en revolución: Ios estampados, los peinados y el color", una iniciativa que nace en la Fundación Universitaria del Área Andina, FUAA, dentro de la facultad de Diseño, Comunicación y Bellas Artes, dando respuesta a las necesidades investigativas planteadas por los lineamientos curriculares de la institución.

\section{Palabras clave}

Años sesenta, colectivos y movimientos, cultura, diseño, historia, moda, revolución, sociedad, tendencias.

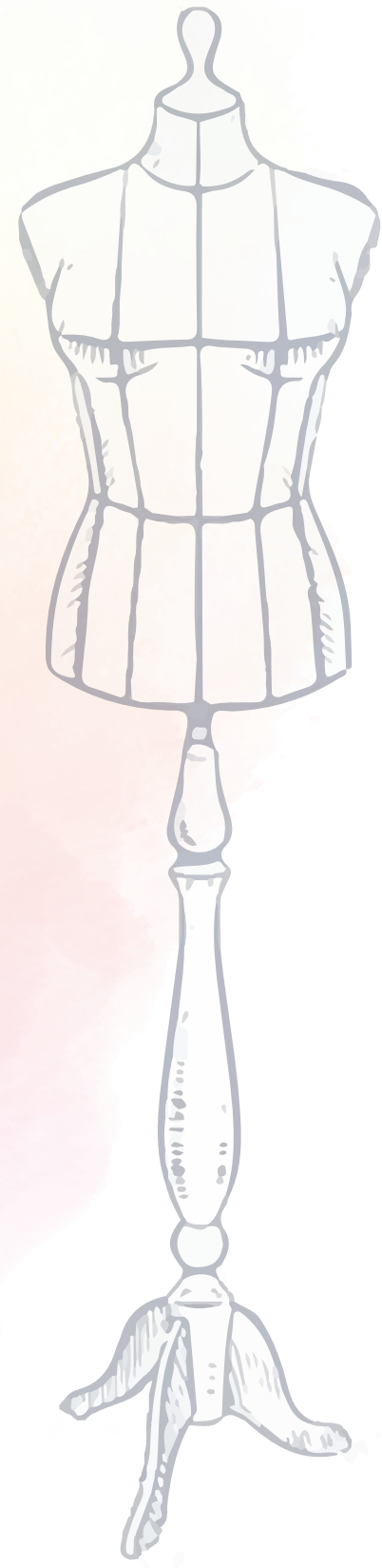




\section{Introducción}

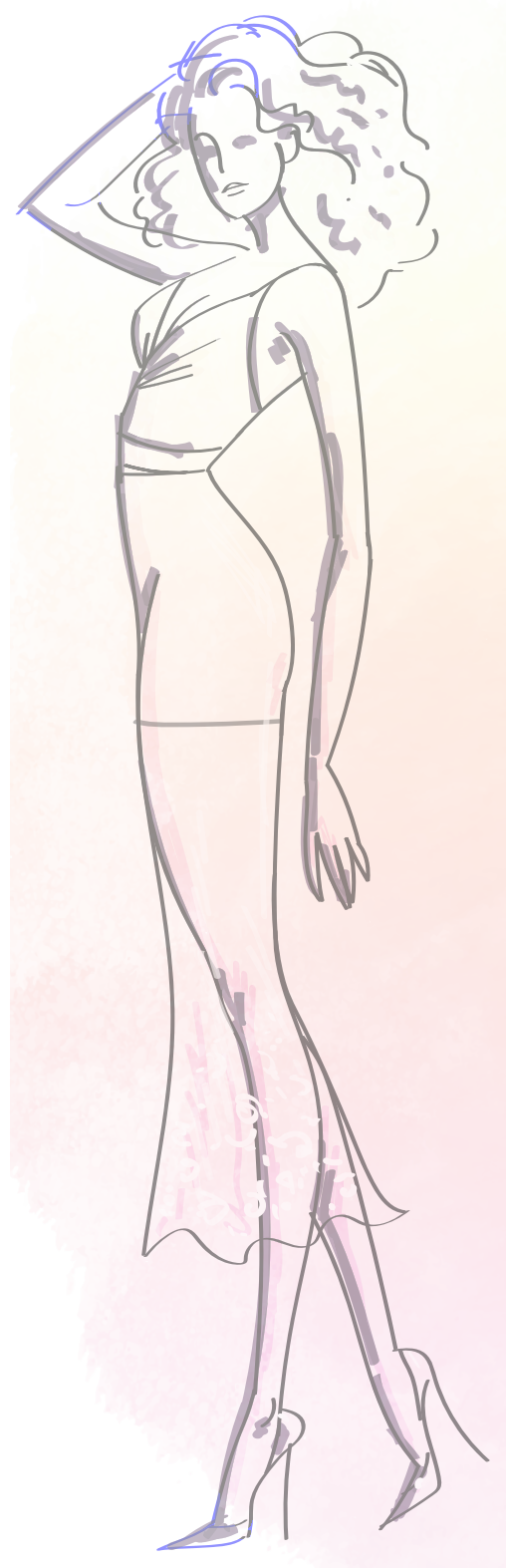

La intencionalidad de este artículo de carácter investigativo está encaminada hacia la visibilidad histórica, política, social y hasta económica de la moda en los años sesenta, debido a su gran impacto y a lo que generó dentro de la industria y de las comunidades textiles. "La revolución en la moda", como es llamado este período extenso y de grandes avances, un grito de protesta que abrió muchos debates y percepciones acerca del verdadero significado de la libertad.

Los hechos relacionados que se irán desarrollando durante la lectura visual del artículo, están ligados también a personajes que, junto con la música, crearon un estilo nuevo, un estilo proclamado y seguido por muchísimas personas, hecho que marca por ser el inicio del verdadero cambio y de las verdadera medidas drásticas como punto de partida.

Incluyéndose aquí también, el tema político, religioso y social, se transforma en un casi punto de partida por las bases que se sentaron como definitivas y únicas, las normas, las leyes y los deberes del ciudadano, siendo la represión y la autoridad, las principales herramientas., cuando, en el inicio de la década, Mary Quant logra destacarse por su valentía y su decisión para imponer atuendos "escandalosos" y "poco recatados", las telas a mitad de ruedo, las piernas exhibidas, los zapatos altos y coloridos, los pechos destapados, las mangas recogidas y sobre todo, el estilo, los estampados y el brillo saturado.

La ruptura entre aquello que se consideraba moralmente correcto y lo que realmente debía llevarse a cabo por las sociedades fue evidente, el aparecimiento de una población juvenil - femenina sobre todo - como un colectivo fuerte e independiente y el planteamiento de la 
propuesta como salida hacia lo injusto y hacia los correctivos aplicados de manera excesiva, abren este excéntrico espacio de la historia. Así mismo como el respaldo de las artes y de las nuevas modas que hoy se conocen como icónicas y emblemáticas.

\section{Método}

Una moda que responde a las necesidades, a la libertad y a la revolución. Dentro del programa de Diseño de Modas de la FUAA, se desarrolla la iniciativa de incluir los procesos investigativos en áreas relacionadas con el planteamiento de ideas creativas y de propuestas para el emprendimiento y la solución de problemas o situaciones sociales, la moda como revolución, incluye datos relevantes y posturas de distintos autores acerca de lo que realmente fue la moda en los años sesenta, de sus alcances, de sus rupturas comerciales, económicas, políticas y religiosas y de la alteración conceptual y real del contexto social. Dentro del marco de esta investigación, se tienen en cuenta autores y máximos exponentes de la época, así como también, la percepción actual de una muestra poblacional, acerca de la forma en la que se llevó a cabo la producción textil y todo lo relacionado con el patronaje y las propuestas de las nuevas tendencias para ese entonces.

A muchos, seguramente, les hubiese gustado vivir o recrear parte de lo que fue este espacio histórico que marcó un hito revolucionario, pues de lo que se tiene registrado, a medida que avanzaba el tiempo dentro de la década, la moda establecía estrategias organizadas y curricularmente alineadas, encaminadas hacia el desarrollo y la explotación de todo el tema little girl, destacándose por sus excentricidades y gustos extravagantes que dejaban ver partes realmente sensuales de quienes la lucían. Así mismo, los grandes momentos, comenzaron su aparición, el cambio dentro de la sociedad, la música la moda y la política, darían un giro definitivo en su funcionamiento y su acercamiento como rol en la sociedad, una revolución con temas a tratar como la discriminación femenina, racial y sexual, la represión de las comunidades LGBTIQ+, los colectivos feministas y animalistas, esto sería una nueva etapa dentro de la historia.

Por otro lado, la moda psicodélica, o moda hippie, estaba llevando consigo una carga bastante amplia de la moda, esta vez enfocada hacia los estampados, los colores y las combinaciones con un toque extravagante y llamativo. En Estados Unidos, la revolución y la disputa por el uso de elementos geométricos, un poco de moda abstracta, comenzaría a dar unos pasos agigantados de lo que pronto se distribuiría a nivel mundial, esto acompañado de los nuevos estilos de cortes que superaban alturas un tanto 
poco convencional, así como las botas en materiales brillantes y lucidos, los cintillos y los peinados pomposos.

Cada uno de los cambios, trajo consigo, molestias e incomodidades en las sociedades adultas y conservadoras que reprimían a toda costa los deseos por la libertad de expresión, por esta razón, las telas extravagantes y los nuevos diseños empezaron a incursionar, las telas tipo plástico, las telas satinadas y con colores vibrantes, así mismo como los jeans bota campana, poco convencionales y bastante salidos de los parámetros de normalidad, así como las faldas y vestidos.

Los comerciales, los medios televisivos y visuales, impusieron poco a poco toda aquella moda proveniente de lugares destacados e icónicos como Hollywood, dando popularidad a las distintas películas que en ese momento se catalogaban como un hit. Uno de los principales influenciadores dentro de estas estrategias de mercado, fue James Dean, el dueño del estilo rebelde y atemporal. Desde los cincuenta y hasta su fallecimiento en los años sesenta, este representante máximo de la moda varonil, desde los comerciales y las grandes pantallas, empezó a marcar poco a poco su estilo, bastante alejado de lo ya convencional, los jeans ajustados, el cabello peinado de otra manera y las camisas o camisetas ceñidas y combinadas, los colores, las texturas, los ajustes, los tamaños y los detalles, hicieron que poco a poco, alrededor del mundo, sus seguidores quisieran imitar su estilo. Un típico rebelde sin causa, inspirado en un personaje que quería remar hacia el lado opuesto, un estudiante de Los Ángeles con prendas emblemáticas saturadas con el azul que se llegó a denominar a finales como la moda vaquera.

Realizando un paralelo entre la concepción historia de la moda a través del tiempo y las tendencias generadas a partir de los distintos gustos en la actualidad, encontramos que aún a la fecha, siguen rescatándose fragmentos de todo esto, lo que tenemos hoy es una moda que, de manera retrospectiva, trae nuevamente detalles, gustos, paletas de colores, textiles, formas, tamaños y patrones figurativos.

Un claro ejemplo lo manejan las marcas reconocidas a nivel mundial durante los eventos de pasarela, nuevamente los pantalones bota campana con tiro alto y ajuste, los vestidos con figuras extravagantes, las botas con corte muy alto, el charol, el terciopelo, la ceda y todas las representaciones visuales de la constante revolución juvenil en la que vivimos. Ahora bien, fuera del contexto de la moda, siguiendo por otros aspectos tales como la política, la religión y la sociedad, aún a la fecha, se siguen rompiendo todas las normativas que van en contra de la libertad de expresión, los colectivos feministas que en ese entonces incursionaron con fuerza, se mantienen, se 
convierten en un legado que a través de sus representaciones corporales, dejan ver que todo ha sido una constante lucha para acabar con la represión y la poca autonomía en las decisiones que conciernen a la sociedad. Un pensamiento que va más allá de la defensa de los estilos y de los códigos de vestimenta, el derecho a poder lucir las prendas y alejarse un poco de los estereotipos, las faldas y los vestidos cortos, la moda sin límites de talla, la moda para todos.

Sin lugar a duda, que la moda de los años sesenta fue una revolución, cada tendencia, cada marca, cada paso agigantado revolucionando el sistema y las formas de pensamiento ligadas a lo convencional y lo rígido. Esta vez, el turno sería para las mujeres que se posicionaron como grandes iconos dentro de la moda, Jackie Kennedy o la modelo Twiggy, dos mujeres que, con botas de tacón y minifalda, representaron los deseos de poder lucir prendas de manera libre y espontánea sin que los centímetros, por encima de la rodilla, afectaran.

Como lo describe Veneziani, en su libro La imagen de la moda (2007):

la hegemonía cultural americana que había dado inicio en el cine, a partir de los 60 se difundió a través de Gran Bretaña, por medio de cintas y discos, de la radio y la televisión.

Una influencia importante fue la del turismo juvenil internacional a través también del mundo universitario y que canalizaba por el mundo la moda juvenil del rock y de los jeans. (p. 48)

Se retoma nuevamente la idea de que la mayoría de los elementos utilizados para transmitir las nuevas tendencias, fueron lo que en ese entonces se conocían como redes de influencia, incluso aún hoy, plataformas como YouTube, Instagram, Facebok, Twitter, Pinterest, Tumblr, entre otras, se posicionan como los principales medios, aquellos que orientan y brindan amplia información para estar al tanto de las nuevas tendencias de vanguardias, tal cual como era antes.

Lo que para Veneziani llegó a ser tan solo parte de un movimiento juvenil universitario, fue una pauta trascendental, justamente porque todo el peso de la lucha y la revolución cayó entonces en manos de aquellos que estaban sometidos bajo algún tipo de régimen estudiantil, intentando escapar un poco de todo aquello considerado convencional. Dentro del mismo contexto, retomando el tema relacionado con las prácticas influenciadoras, y lo que en ese entonces se transmitía mediante periódicos, revistas y medios televisivos, Twiggy (modelo y máxima exponente de la moda sesentera), lució la mayoría de los trajes y tendencias que, para ese entonces, eran un boom. 
Vicente Gallart (2014), en su libro Irresistibles, 100 años de it girls en la moda, menciona también que:

Después de desencadenar toda una serie de aparecimientos y revolucionar el mundo de la moda, en 1967, Twigy, apareció en Nueva York, cuando allí la prensa la esperaba ansiosa por descubrir cómo era en persona la modelo de la que todo el mundo hablaba en Europa, The New Yorker, Life, Newsweek y los medios impresos más importantes de Estados Unidos, no dudaron en dedicar páginas y páginas a la nueva itgirls que llegaba al país para conseguir que todas las chicas imitaran su estilo trasgresor y en ocasiones extravagante. Su imagen andrógina fue perfecta para que los cándidos minivestidos babydoll, las prendas de reminiscencias militares masculinas y los looks minimalistas basados en los trajes de Nehru y monos de estilo Space Age propuestos por Cardin, Courrreges, Rabanne, Saint Lauren o Gernereich luciera como debían y, al instante, se convirtieran en todo un éxito de venta en las boutiques.

Un estilo bastante recaído en la imitación, algo similar a lo que sucede hoy, modelos influenciadores que encaminan su carrera hacia la búsqueda de un espacio dentro de todo este mundo de la moda, lanzando sus propias marcas, creando sus propias etiquetas y generando algún tipo de estereotipo de belleza y de status.

\section{Resultados}

Estudio de la percepción social acerca de los temas de moda en los sesenta. Según lo planteado en un inicio, el paradigma sigue centrado en el hecho de que la moda siempre ha llegado, y llegará, como una corriente que se contagia en las masas, sabemos que cuando dentro de un mismo círculo social, alguien incluye algún tipo de prenda, o accesorio, que sea de gusto común, de inmediato está dejando una puerta abierta hacia aquello que solemos llamar imitación, y así es la moda, es repetitiva a veces, es innovadora, es casual, es imitadora, es exclusiva, es extravagante, la moda es diversa, por eso, tomar esta temática de los sesenta, permite incluirse en un debate directo sobre aquello que se ha rescatado, lo que se ha mantenido y lo que seguramente en un futuro se retomará.

Mediante esta investigación de carácter cualitativo, la población se mostró interesada en el tema, de hecho, surgieron una serie de interrogantes y de problemáticas a raíz de lo que debería considerarse como verdadera revolución, todo esto por el hecho de que cuando se marcó el inicio de una nueva etapa en la sociedad, también 
se habló de una corriente influenciadora desde el modelaje, no solo en lo que concierne a la moda, sino también partiendo desde la talla y la estatura ideal, los rasgos corporales necesarios para poder adecuarse a esta moda, entonces, ¿realmente es una incursión social y revolucionaria? O, por el contrario, es una red de influencias con prototipos limitados. De la misma forma, se establecieron las percepciones y se clasificaron dentro de lo que para el grupo de personas se considera relevante cuando se habla de moda sesentera.

\section{TABLA 1}

PARALELO COMPARATIVO DE PERCEPCIONES: ¿LA MODA EN LOS SESENTA, REVOLUCIÓN O IMITACIÓN?

\begin{tabular}{|c|c|}
\hline Moda revolucionaria & Moda de imitación \\
\hline $\begin{array}{l}\text { Moda creada para poder revolucionar } \\
\text { el mercado y la forma de ver de cada } \\
\text { persona. Es una moda con objetivos } \\
\text { claros, aún prevalece y aún logra con- } \\
\text { siderarse parte del presente y hasta del } \\
\text { futuro. }\end{array}$ & $\begin{array}{l}\text { Seguir un patrón ya establecido y consi- } \\
\text { derar que se está haciendo revolución, } \\
\text { es un concepto bastante cercano a la } \\
\text { verdad, la única revolución es la que se } \\
\text { crea y se transforma, no la que se imita. }\end{array}$ \\
\hline $\begin{array}{l}\text { Es satisfactorio lograr dejar algún tipo } \\
\text { de marca o de reconocimiento en la } \\
\text { historia, la moda de los años sesenta lo } \\
\text { hizo, tuvo sus propios estilos, se desta- } \\
\text { có y además, se incursionó en el merca- } \\
\text { do de forma rápida. }\end{array}$ & $\begin{array}{l}\text { La moda siempre ha tenido sus propios } \\
\text { lineamientos y en su gran parte ya traen } \\
\text { estereotipos incluidos, esto es que ya } \\
\text { sabes de cierta forma, como debe ser tu } \\
\text { contextura ideal para poder lucir algún } \\
\text { tipo de prendas diseñadas. }\end{array}$ \\
\hline $\begin{array}{l}\text { Se considera revolución todo aquello } \\
\text { que logra transformar y modificar la } \\
\text { realidad, la revolución de la moda se- } \\
\text { sentera lo fue, los cambios políticos, } \\
\text { económicos y sociales, marcaron un se- } \\
\text { guimiento de todo el trabajo que desde } \\
\text { un inicio se realizó, fue algo como una } \\
\text { creación de marca propia. }\end{array}$ & $\begin{array}{l}\text { Como el caso de Twiggy, hay muchos } \\
\text { en todo el país y en el mundo, la moda } \\
\text { a veces da la impresión de ser creada } \\
\text { solo para ciertos perfiles, con certeza no } \\
\text { sabremos si durante los años 60, tam- } \\
\text { bién existieron casos de exclusión o de } \\
\text { clasificación por prendas y códigos de } \\
\text { vestimenta. }\end{array}$ \\
\hline
\end{tabular}




\section{Discusión}

La contextualización amplia, permite que la temática trabajada pueda ser más comprendida, pueda valorarse desde distintos puntos de vista y sea tomada como una parte importante dentro del contexto histórico, la moda revolucionaria, es una gran parte de todo aquello que en un pasado se vivió, todo lo que se relacionó directamente con los movimientos de rock, de pop, de música protesta, todo lo que nació durante esa época y que hoy logra ser tan importante.

\section{Conclusión}

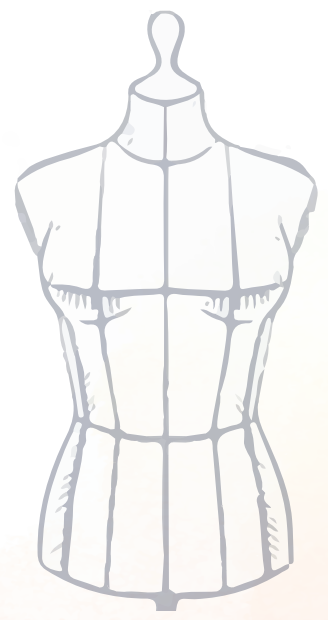

Este artículo contiene datos y percepciones vistas desde la moda y desde el diseño, no como uno, sino como elementos individuales que pueden formalizar algún tipo de concepto. Hablar de moda es abarcar distintos aspectos relacionados con la época y con el contexto general. Hablar de moda es enterarse de cada hecho arraigado, de cada surgimiento, de cada razón de ser de algún tipo de tendencia o de costumbre, la moda es muy diversa, los datos que se encuentran en ella también.

\section{Sexto semestre: diseño de moda internacional aplicado a ropa interior y deportiva}

Núcleo problémico. Producción de artefactos (diseño industrial e industrias creativas).

Subtema de investigación. Sensualidad divertida

\section{Palabras clave}

Contrastes, exploración, interior-exterior. 


\section{Objetivo}

Desarrollar competencias investigativas en los estudiantes de sexto semestre de Diseño de Modas en la Fundación Universitaria del Área Andina; investigando sobre el paralelismo entre lo retro, la tecnología y las técnicas artesanales textiles, con el fin de diseñar una colección en línea femenina para el universo de vestuario de ropa interior y vestidos de baño.

\section{Entregables}

\emana 8

» Artículo de investigación

» Moodboard de concepto

» Bitácora de diseño

$》$ Semana 10

» Un conjunto de ropa deportiva femenina de dos piezas

$»$ Portafolio

» Introducción

» Moodboard de concepto

» Macro tendencias / micro tendencias y su aplicación conceptual (materiales textiles, carta de color, visión y prendas clave).

» Perfil del consumidor (geográfico, psicográfico y demográfico)

» Universo del vestuario

» Ocasión de uso

» Bitácora de diseño de colección y de diseño de calzado

» Colección de diez diseños femeninos, cinco de ropa interior y cinco de vestidos de baño. Digitales

» Dibujos a plano colección.

» Patronaje digital de los prototipos en software audaces

» Propuesta de calzado.

» Página web (WIX).

» Un conjunto de ropa interior femenina

» Un vestido de baño femenino y calzado 


\section{Bases textiles}

Encajes elásticos y demás insumos específicos de la corsetería. Lycra nylon para vestidos de baño, telas con nanotecnología para natación, lycra poliéster para ropa deportiva, impermeables, neoprenos.

\section{Entregas finales}

Ver figura 30.

\section{FIGURA 30}

DISEÑO INTERNACIONAL. ROPA INTERIOR Y DEPORTIVA. JULIO MARTÍNEZ IMBACHI

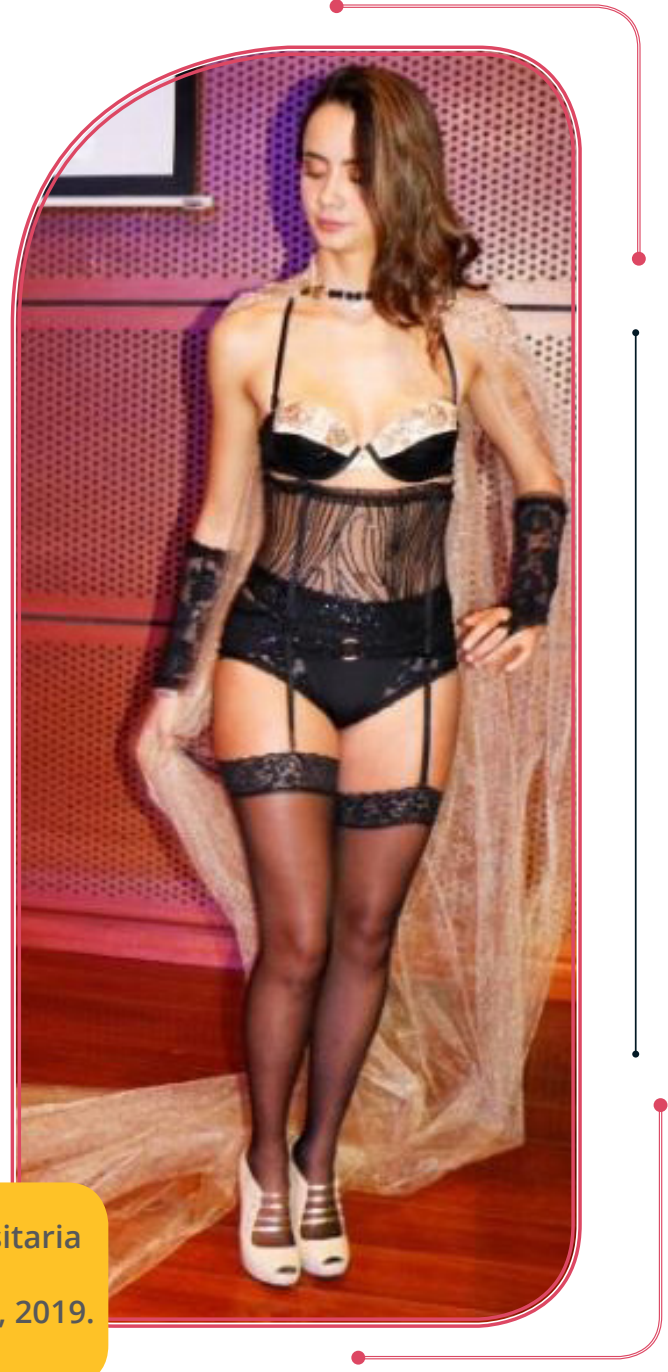


Fente: Riachi, 2019. Auditorio Fundación Universitaria del Área Andina, sede Bogotá. Programa Diseño de Modas.

\section{[T3]Artículo resultado final: Aspectos formales del terror aplicados} a una colección de moda. Zulay Daniela Rivera Matiz

\section{Resumen}

El miedo a lo largo de la historia ha tenido connotaciones negativas hasta el punto de querer evadirlo completamente, pero es cuando se convierte en terror que puede generar efectos negativos en quien lo padece. Gracias al análisis realizado a la marca de moda alternativa Killstar, se trata de determinar cómo puede evidenciarse el terror en las prendas más allá de los estampados. Se tienen en cuenta importantes escritores del género del terror que han influenciado a directores de cine en la realización de películas de terror del subgénero serie $B$, de las cuales se realiza una investigación cualitativa para abstraer elementos formales del terror que pueden ser aplicados en una colección de moda que le apuesta a lo sensual como eje unificador de todos los elementos del horror hallados en la investigación.

\section{Palabras clave}

Humor negro, Killstar, miedo, monstruo, películas, terror, sensualidad, serie B.

\section{Introducción}

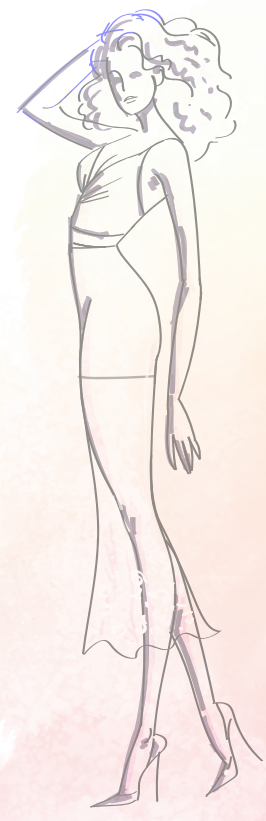

El miedo es una emoción tan antigua como la humanidad misma. A través de la historia de la raza humana este sentimiento ha acompañado a todas las personas en innumerables experiencias y hechos que suelen traer malos recuerdos. Por esta razón, es considerado como algo malo, algo que inhabilita a quien lo posee de comportarse de manera normal o racional, pero lo cierto es que ha sido gracias al miedo que los humanos se han mantenido vivos por tantos milenios, ya que es esta sensación la que les ha permitido protegerse y evadir situaciones que podrían ponerlos en verdadero peligro.

Cuando el miedo alcanza su máxima escala se convierte en terror, y es este sentimiento el que realmente paraliza a una persona y hace que sus pensamientos dejen de fluir 
adecuadamente. Con este sentimiento han jugado numerosos directores de cine que buscan generar sensaciones extremas en los espectadores a través de sus películas de horror. También han surgido marcas de moda que ofrecen un estilo alternativo y oscuro con fuertes influencias de elementos terroríficos y que los expresan a través de llamativas y creativas piezas gráficas estampadas en las prendas.

Lo interesante, en términos de moda, es que aún no se ha explorado demasiado, más allá de dichas piezas gráficas, para transmitir la sensación de terror, entonces ¿cómo se puede generar una colección de moda para una marca comercial como Killstar que comunique la sensación de terror más allá de lo gráfico?, ¿es acaso el momento de explorar el miedo intenso a través de las formas de una prenda de vestir? y ¿cómo se hace la conexión de los conceptos de terror, sensualidad y diversión para proponer un nuevo estilo de vestir tanto para la marca Killstar como para otros usos comerciales?

\section{Killstar}

Killstar es una marca de ropa alternativa creada en el año 2010 en Inglaterra. Es reconocida, actualmente, como una de las principales marcas que ofrece propuestas diferentes en cuanto estilo y a variedad de productos. Nació con la intención de ofrecer a consumidores con gustos extraños la oportunidad de adquirir productos de calidad con los cuales se sintieran identificados y cómodos a la hora de usarlos, y que fueran como una extensión de ellos mismos. Los estilos con los que se pueden definir las prendas de vestir son el Nu Goth y el Pastel Goth, siendo ambas variantes del estilo clásico gótico, pero con un toque mucho más moderno y urbano.

Su ADN se puede definir como una "Marca de moda y estilo de vida con un toque de oscuridad que canaliza el poder emocional y la energía pura en cada hilo" (Killstar, 2010). Se destaca por la simbología oscura y mágica en sus estampados que hace referencia a la oscuridad y a personajes demoniacos, también se caracteriza por diseñar prendas que contienen frases sarcásticas alusivas a la muerte y a lo gótico. El universo del vestuario dentro del que se enmarcan sus productos es el casual, contando con una muy buena variedad de productos dirigidos al público masculino y femenino con gusto por lo sobrenatural y que no temen al hecho de mostrarse tal y como son en su interior a través de su estilo.

Killstar busca que sus productos sean primordialmente cómodos y de buena calidad para sus clientes, es por esto que dentro del análisis que se le ha hecho a la 
marca se pueden encontrar siluetas en su mayoría holgadas y un poco largas, además del uso de materiales que se sientan bien al tacto con la piel como lo son algodones, sedas y terciopelos, esto va siempre de la mano con las características piezas gráficas demoniacas, cósmicas y terroríficas que diferencian a Killstar de otras marcas de ropa alternativa.

\section{El miedo y el terror}

Guy de Maupassant dijo en su conocido relato El miedo, hacia 1882:

El miedo (y hasta los hombres más audaces pueden tener miedo) es algo espantoso, una sensación atroz, como una descomposición del alma, un espasmo horrible del pensamiento y del corazón, cuyo mero recuerdo provoca estremecimientos de angustia. (...) El verdadero miedo es como una reminiscencia de los terrores fantásticos de antaño. Un hombre que cree en los fantasmas y se imagina ver un espectro en la noche debe de experimentar el miedo en todo su espantoso horror.

A través de dicho relato, el escritor francés da testimonio de su propia experiencia con el miedo, haciéndolo ver como el peor de todos los sentimientos y como el causante de sus más grandes desdichas.

Aunque la concepción de miedo más aceptada por la sociedad es similar a la dada por Maupassant, se debe ir un poco más lejos y hacer notar como el miedo a acompañado, por muchos milenios, el crecimiento evolutivo, tanto biológico, como mental del hombre. Ha sido gracias al miedo que, no solo la especie humana, sino también otras especies animales, han podido sobrevivir al peligro, alejándose de él o evitándolo, ya que esta emoción les ha permitido ser mucho más conscientes de las consecuencias fatales a las que podrían enfrentarse si no se alejan de él.

Como especie, hay miedos en común que todos los humanos comparten, esto se debe a que, a lo largo del proceso de evolución, estos miedos han quedado grabados en el código genético de las personas y se han ido pasando, de generación en generación, hasta la actualidad, sin ser conscientes de ello. El miedo primordial, del que se puede decir que se desprenden casi todos los demás miedos, es el miedo a la muerte. El hecho de pensar que en un determinado momento todo lo que se ha conocido en vida va a llegar a un fin ha aterrorizado siempre al ser humano, pero lo que le causa aún más miedo es el desconocimiento acerca de lo que sucede con él cuando su vida finaliza. Un miedo que está muy ligado a la muerte es el miedo a lo desconocido 
y cómo esto, que no se conoce, puede llegar a afectar, de manera negativa, a quien tiene la inquietud de no poder conocerlo.

Ahora, hablando en términos de moda, este miedo a lo desconocido se puede reflejar en una prenda, no sólo a través de estampados gráficos que dejan ver cráneos y huesos que recuerdan a la muerte y sus efectos. Si lo que realmente causa miedo y angustia en las personas es la imposibilidad de conocer algo, entonces, es el momento de proponer alternativas que vayan más allá de lo gráfico e intervengan con las formas de las prendas. ---

Teniendo en cuenta que la colección de moda a la que va dirigida todo el estudio sobre el miedo, el terror y afines es una colección de ropa interior, vestidos de baño y ropa deportiva, se puede empezar a jugar con las siluetas y cortes que componen las prendas, ya que es usual que, incluso las marcas de ropa alternativa, diseñen sus productos de tal manera que los estampados sean, en la mayoría de casos, los que les dan vida y ayudan a diferenciarlos, pero cuando se analizan como se verían sin las piezas gráficas, dejan un sinsabor ya que parecen ser únicamente prendas básicas que no han tenido mucha profundidad a la hora de pensar en su diseño.

Para darle un valor agregado a las prendas, a partir del miedo a lo desconocido, se ha determinado que una opción viable es la de crear piezas compuestas por capas de diferentes bases textiles que dejen ver partes de las que estén debajo, esto con el fin de crear en el consumidor la expectativa de querer ver más allá de lo que en un principio puede ver a simple vista.

Por ejemplo, si sobre una base textil estampada como la power se sobrepone otra como una malla deportiva grande en un tono que contraste o sobresalga, va a generar en la persona que lo observa, la necesidad de ver aquello que, gracias a la malla es desconocido a sus ojos, de esta manera tendrá la oportunidad de disfrutar de un producto que va más allá de lo gráfico para invitarlo a interactuar mucho más con él a partir de la manera en cómo está construido.

Volviendo al punto central del miedo, hay ocasiones en que éste se vuelve tan intenso y le da tal sensación de vulnerabilidad a quien lo siente que se transforma en terror. Cuando este sentimiento toma el control de la persona, puede llegar a paralizarlo e incluso hacer que sus pensamientos sean difusos, llevándola a no tener autonomía sobre sí misma, convirtiendo esta situación en otro de los grandes temores del ser humano que es la perdida de la libertad. Al mencionar la libertad, no se toma esta desde el punto de vista de verse privado de ir normalmente por el mundo por culpa del encierro físico del cuerpo en una celda, se habla de la imposibilidad de controlar 
los movimientos propios que, en una circunstancia cotidiana, serían tomados como algo normal y natural que cualquier ser vivo hace.

También, se hace referencia al hecho de no poder controlar los pensamientos, y que estos fluyan de manera irracional. Aunque todos estos son miedos, o temores, también se pueden tomar como efectos de los mismos, ya que, en una situación extrema, de máximo terror, se pierde, en cierto punto, la noción de ser humano, actuando descontroladamente.

Otras de las causas ligadas al terror, y que están escritas en los códigos genéticos de los seres humanos, son el temor a la mutilación y al envenenamiento. El miedo a la mutilación "se trata del temor de perder cualquier parte de nuestra estructura corporal, la idea de tener límites en la movilidad de nuestro cuerpo o de perder la integridad de cualquier órgano, parte del cuerpo, o la función natural" (Albrecht, 2012). El miedo al envenenamiento está relacionado con animales como las arañas, las serpientes o los escorpiones, que le provocan daños y dolor al ser humano, desde sus primeras interacciones, hace muchos siglos, acrecentando el temor y heredándolo a través de las generaciones. Es por esta razón que, desde el momento en que una persona nace, el miedo a dichas especies, o similares, ya viene aprendido y, a lo largo de su vida, aunque nadie se lo diga directamente, identifica a estos animales como fuente de peligro, por lo cual decide evitarlos para protegerse del daño.

Los temores que afectan directamente al cuerpo humano han sabido ser muy bien aprovechados y explotados por los representantes del género del horror desde la mitad del siglo xix hasta el día de hoy, plasmándolos en grandes cantidades de piezas literarias y cinematográficas al jugar con la mente humana y con lo que más terror y ansiedad le produce. Los efectos y desarrollo de algunas de estas piezas serán abordados más adelante para estudiar algunos referentes del cine de terror.

\section{Películas de terror de los años ochenta}

"La emoción más antigua y más intensa de la humanidad es el miedo, y el más antiguo y más intenso de los miedos es el miedo a lo desconocido" (Lovecraft, s.f.).

Cuando se piensa en los grandes representantes del género del terror en la literatura, y que siguen teniendo gran influencia hoy en día, se vienen a la mente tres importantes personajes: Edgar Allan Poe (1809-1840), Howard Phillips Lovecraft (1890-1937) y Stephen King (1947-hoy). Estos escritores lograron captar la atención de los lectores, y posteriormente de los cineastas, gracias a su increíble capacidad de atemorizar, a 
través de sus historias, jugando con los más profundos miedos de los humanos y por su forma de escribir expresando esos miedos que en muchas ocasiones eran imaginarios como si fuesen lo más reales posibles.

A lo largo de sus vidas contaron en sus cuentos y novelas, los miedos cotidianos del hombre que, aunque eran reales, no se atrevían a enfrentar, pero también describieron terrores cósmicos traídos de lo más profundo de la mente humana para aterrorizar a todo aquel que se atreviera a leer sus historias.

Es importante hablar y tener en cuenta a los autores ya mencionados, puesto que han sido sus obras la inspiración para la realización de muchas de las películas para los apasionados del horror y del suspenso. Inspiradas en la obra de Edgar Allan Poe se destacan The Raven (Landers, 1935), La máscara de la muerte roja (Brand, 1989) y Narraciones extraordinarias (García, 2015). Narraciones de H.P. Lovecraft inspiraron Re-Animator (Gordon, 1985), Evil Dead 2 (Raimi, 1987) y The call of Cthulhu (Leman, 2005). Por último, la mayoría de las obras de Stephen King han sido llevadas al cine como Carrie (de Palma, 1976), Creepshow (Romero, 1982) y Pet Sematary (Lambert, 1989).

Los años ochenta fueron una década que, se puede decir, marcó un antes y un después en la contemporaneidad de la raza humana, además de haber sido la época en la que algunas de las películas anteriormente mencionadas vieron la luz, y que hoy, se conocen como películas de culto, ya que tienen millones de admiradores en todo el mundo y son proyectadas en público en celebraciones como Halloween.

El cine de terror ochentero se caracterizó por mostrar tramas del subgénero slasher, en donde un asesino serial, usualmente enmascarado, asesinaba de forma brutal a adolescentes despreocupados y confiados, y por la naturaleza de estas muertes se empezaron a mostrar con mayor fuerza vistazos del subgénero gore, que es extremadamente explícito en cuanto a violencia.

\section{Subgénero serie B: referentes}

Cuando las historias sangrientas, en donde quienes captaban más la atención eran los villanos encarnados en asesinos seriales, empezaron a ser demasiado predecibles y ya no llamaban tanto la atención de los espectadores, como en sus primeros años, resurgió un subgénero que había decaído en la década de los cincuentas, el cine de terror serie B. El nombre hace referencia a la connotación que recibía por parte del público, como la clase de cine más inferior de todas. Este subgénero se caracterizó por producir películas de muy bajo presupuesto con efectos especiales pobres y experi- 
mentales. Es usual que en las películas de serie B se observen imágenes cargadas de litros y litros de sangre falsa y sesos regados por todo el lugar, lo que da la sensación de repulsión y asco.

A través de las películas de este subgénero, los directores supieron jugar con algunos de los miedos más profundos de las personas, como lo son la muerte y las mutilaciones, creando un especial foco en el observar el dolor físico para crear una sensación de incomodidad y desagrado. Las características que se han descrito hasta ahora hacen parecer al cine de terror serie B a los demás subgéneros, pero lo que realmente lo diferencia de los demás es el uso del humor negro a lo largo de todas sus tramas, que en ocasiones puede llevar a pensar que las películas son meramente parodias. Lo que ayuda a que cada historia tenga ese toque de comedia son los efectos especiales que no se ven realistas, y la actitud de los personajes frente a situaciones de peligro, ya que, en ocasiones, al tratar de protegerse de él, terminan llevando a cabo acciones que los llevan a lastimarse a sí mismos.

\section{Re-Animator (Stuart Gordon, 1985)}

Re-Animator es una de las películas de culto tipo serie B más conocidas y admiradas por los fanáticos del terror. Está inspirada en el relato de terror de H.P. Lovecraft Herbert West: Reanimador de 1922. Narra la historia del doctor Herbert West que ha hecho innumerables estudios sobre la muerte y tiene el propósito de revivir a los muertos a través de un suero que el mismo ha creado, pero los resultados que obtiene, al aplicar el suero a algunos cadáveres, no son lo que él esperaba, ya que éstos se convierten en un tipo de zombis salvajes con fuerza sobre humana que quieren acabar con él.

Como elementos característicos del miedo que se han podido encontrar al ver la película, están en, primer lugar las figuras de los zombis y lo grotesco de su descomposición al ser cadáveres reanimados para actuar como si tuvieran vida, nuevamente, causando sensaciones de asco y repulsión en quienes ven la película. Un elemento importante es el del suero mágico en la jeringa utilizada para darle vida a los cadáveres, ya que, es a través de dicho objeto, que el doctor puede iniciar los resultados de sus investigaciones. Una de las escenas más recordadas, e importantes de la película, es cuando el doctor West decapita a su superior que intentaba robar su suero para patentarlo como suyo, West experimenta con la cabeza mutilada regresándola a la vida en contra de toda lógica médica. 
Al pensar en cómo estos elementos característicos pueden utilizarse para implementarse en una colección de moda dirigida a Killstar, se propone utilizar el elemento del suero como dador de vida en aplicativos como estampados que brillen bajo la oscuridad, ya que del suero emana un brillo tenue a lo largo de la trama. La figura de los zombis violentos, con fuerza descomunal, se puede interpretar a manera de patterns, o en contrastes fuertes de los materiales con los que pueden realizarse las prendas.

El simbolismo de la cabeza decapitada puede tomarse en cómo el cuerpo se ve divido al usar las prendas, por ejemplo, si dentro de una prenda superior se diseña una pieza que rodee el cuello, o se utiliza un accesorio muy grande como un collar, se creará la ilusión de que la cabeza de la persona no hace parte del cuerpo.

\section{Creepshow (George A. Romero, 1982)}

Creepshow está inspirada por los relatos de terror Weeds y The crate del escritor Stephen King. Empieza contando la historia de un niño al que su papá le quita un cómic que estaba leyendo al contener historias de terror. La trama avanza cuando un fantasma se le aparece al niño para invitarlo a conocer, de primera mano, las cinco historias que se narran en el cómic.

La primera historia es Día del padre, en donde el cadáver putrefacto de un padre sale de su tumba para tomar venganza de su familia, ya que cree que fue la causante de su muerte. La segunda historia es La solitaria muerte de Jordy Verrill, que narra cómo un campesino, interpretado por Stephen King, encuentra un meteorito en su jardín, al hacer contacto con él empieza a transformarse en un monstruo cubierto de vegetación.

La tercera historia es La marea, en donde un hombre busca vengarse de su esposa y su amante torturándolos al dejarlos enterrados vivos a la orilla del mar, su suerte cambia cuando ellos vuelven en forma de fantasmas en descomposición para aplicarle el mismo castigo. La cuarta historia es La caja, que narra cómo, en una caja escondida por más de cien años en una universidad, ha vivido una criatura monstruosa y hambrienta que se convertirá en la pesadilla de un grupo de personas. La quinta, y última historia, es La invasión de las cucarachas, en donde un hombre de negocios, cruel y avaro, con fobia a los insectos, termina encontrando la muerte en sus peores miedos.

Al analizar las historias se ha encontrado que, a partir de cada historia se pueden extraer elementos representativos que, en el lenguaje de la moda, pueden interpretarse como una conceptualización formal del miedo. El cuerpo putrefacto del padre de la 
primera historia muestra hinchazón en todo el cuerpo debido al proceso de descomposición, así que esto puede ser traducido como volúmenes en las prendas de vestir.

La metamorfosis que sufrió Jordy Verrill, en la segunda historia, terminó por convertirlo en una criatura que deja rastros casi nulos del ser que solía ser. Se encuentra que este cambio puede ser aplicado a la funcionalidad de las prendas superiores de la colección, ya que, al usarlas de una determinada manera, pueden funcionar como prendas internas, pero si se cambian las prendas que la acompañan pueden funcionar como prendas externas.

El mar y la fluidez de sus olas fueron partes muy importantes de la tercera historia, ya que fueron estos elementos los que terminaron con la vida de los protagonistas. La propiedad de este cuerpo natural de agua, capaz de cubrir todo y llevárselo hacia sus adentros, puede trasladarse a prendas como salidas de baño, levantadoras, tops y busos, que cuenten con piezas superiores como capotas de gran tamaño que permitan cubrir gran parte de la cabeza y dejen ver sólo una parte de la cara, creando así una sensación de misterio, y en cierto modo de ahogamiento.

El monstruo que vivió tantos años sólo en la caja de la cuarta historia se interpreta como el miedo a lo desconocido, pero también como miedo al otro, y a la maldad que puede ocultarse en él por su aspecto físico feroz y animal. Con la realización de varios bocetos, luego de observar con detenimiento esta historia, se ha llegado a determinar que la mejor manera de mostrar al monstruo indirectamente, no necesariamente a través de un estampado, es creando la ilusión de que la cara de un monstruo está situada cuando una prenda superior e inferior se visualiza como conjunto.

El miedo a algo pequeño como una cucaracha, en la última historia, que muchas veces no puede ser percibida a primera vista, se ha interpretado como los pequeños detalles que hacen que una prenda se diferencie y que pueden ir desde pequeños prints, ubicados en ciertas partes de la prenda, hasta elementos como remaches, taches $u$ ojetes funcionales y decorativos.

\section{The monster squad (Fred Dekker, 1987)}

The monster squad, o El escuadrón anti-monstruos, es una película que reúne a los monstruos clásicos del terror y a un grupo de niños, aficionados a sus historias, que se proponen a enfrentarlos y detenerlos por todas las muertes que están causando en su ciudad. La única oportunidad que tienen los niños para vencer a los monstruos la encuentran en un talismán que se encuentra perdido, y en la recitación de un antiguo 
conjuro escrito en el diario de un famoso caza fantasmas de hace cien años, Abraham Van Helsing, pero para hacerlo, requerirán la ayuda de un extraño personaje alemán a quien antes consideraban un monstruo.

Uno de los elementos más interesantes para tener en cuenta de esta película, es el contraste entre el carácter sobrenatural y salvaje de los monstruos, y la inocencia de los niños que tratan de combatirlos. Esto se puede reflejar en las prendas, haciendo fuertes contrastes entre los colores y las bases textiles que las componen para así lograr un efecto visual muy llamativo.

Teniendo en cuenta la naturaleza de cada uno de los monstruos, se pueden abstraer características que se pueden hacer visibles en el lenguaje de la moda. Drácula es el vampiro más famoso de todos los tiempos, es el reflejo de la inmortalidad y el poder en su máxima expresión, pero si lo comparamos con cualidades mucho más humanas, también se le identifica con la sensualidad y el lujo que pueden verse representadas en la utilización de materiales con intervenciones textiles que le den la sensación de tener relieve, y que se implementen en escotes sutiles y siluetas insinuantes, sin llegar a ser vulgares. Cuando se transforma en murciélago, las formas y texturas de este animal recuerdan a las de bases textiles como sintéticos, o el terciopelo, y a la traslucidez de materiales como encajes, blondas y velos.

El monstruo de Frankenstein es la representación del temor al otro gracias a la deformidad de su aspecto físico. Producto de un doctor jugando a ser un dios creador, está construido a partir de las partes de cadáveres diseccionados y se mantiene con vida gracias a fuertes descargas eléctricas provenientes de una tormenta. Esta característica, de estar hecho con diferentes partes, puede llevarse a cabo al realizar una prenda compuesta por diferentes bases textiles que se contrasten entre sí, además de la creación de sistemas de cierre, como acordonados, que ayuden a dar la ilusión de que la prenda esta cosida por medio grandes y gruesas costuras, como las que se pueden observar en el cuerpo del monstruo.

El hombre lobo es misterioso gracias a su doble identidad, puede ser un hombre normal igual a todos los demás, pero cuando la luna llena aparece, se convierte en una criatura salvaje que no teme mostrar su ferocidad y hambre de carne. Esta dualidad se relaciona un poco con la sufrida por Jordy Verrill en Creepshow, con la diferencia de que el hombre lobo puede volver a su estado de hombre cada cierto tiempo. Así, que ese personaje también puede ser interpretado en la doble funcionalidad de las prendas, pero además en la utilización de accesorios brillantes haciendo alusión a que sólo puede morir sí se le dispara con balas de plata, y grandes, que se comporten como extensiones de las prendas 
y hagan que éstas cubran más el cuerpo, como el pelaje cubre al monstruo en su transformación. Ejemplos de estos accesorios son los arneses y los ligueros.

La momia es un monstruo histórico, que inmediatamente dirige el pensamiento de quien escucha su nombre hacia Egipto, lugar del que proviene. Su mayor característica es la forma en la que su cuerpo está totalmente cubierto de vendas gracias al proceso de momificación al que fue sometido hace miles de años. La interpretación de este particular aspecto físico se da en la implementación de tiras de tela en las prendas para ayudar a crear un concepto de envolvimiento, pero también como valor agregado en la construcción de escotes y prendas que van hasta la cintura.

El monstruo de la Laguna Negra es un hombre-anfibio oculto en las profundidades de una laguna, como el último de su especie, y que ha aprendido a vivir sin que ningún humano interrumpa su tranquilidad. Es la encarnación del miedo que sienten los seres humanos a perder su humanidad y llegar a tener algún punto en común con los animales. Su cara, entre humano y pez, es uno de los aspectos que más atemoriza y que, al igual que el monstruo de La caja de Creepshow, puede mostrarse indirectamente en la composición de panty y brasier de los conjuntos de ropa interior.

\section{Evil dead 2 (Sam Raimi, 1987)}

Secuela de The Evil Dead (Raimi, 1981), narra la historia de una joven pareja que pasa la noche en una cabaña en la mitad del bosque. Al reproducir unas viejas cintas de audio se puede escuchar como un científico recita pasajes del Necronomicón o Libro de los muertos (en honor al libro ideado por H.P. Lovecraft y que sirvió de inspiración para la película). Una vez que la cinta termina, una fuerza demoniaca y sobrenatural despierta en el bosque, con la intención de apoderarse del cuerpo y alma de todos aquellos que se atrevan a adentrarse en la oscuridad de la noche.

Se puede decir que toda la saga de Evil Dead es uno de los máximos referentes del cine serie B y por la cual Sam Raimi alcanzó la fama como director. Se destaca el personaje de Ash Williams, ya que, a lo largo de la película, tiene que enfrentar sus temores para protegerse a sí mismo, y a quienes lo acompañan. De esa manera se hace presente el miedo como herramienta del ser humano para preservar su seguridad y protegerse del peligro. Este sentido de protección puede interpretarse, en la colección, a través de prendas que cubran una buena cantidad de piel, sin llevarlas al punto de que se vuelvan aburridas, ya que esto se puede lograr con bases textiles que den la posibilidad de generar transparencias. 
Quizás, una de las razones por las cuales esta segunda parte de la saga se hizo tan famosa, fue por la utilización de recursos como los efectos especiales para generar escenas violentas y repugnantes. Bien recordados son los personajes cuando se encuentran en estado de posesión demoniaca, ya que se asemejan a la figura del zombi, pero mucho más violento y con metas mucho más oscuras. Aquí, nuevamente, se refleja el miedo al otro y a su maldad, así como también a la perdida de la humanidad. Más notable, es aún el miedo a la mutilación, ya que la manera en que Ash se deshace de las personas poseídas es de lo más violenta, al utilizar armas blancas como hachas, sierras eléctricas y cuchillos de carnicería.

La esencia de este miedo puede transmitirse a través de la moda, implementando cortes en las prendas que se sitúen justo por encima de las articulaciones del cuerpo, que es precisamente a donde Ash guiaba sus armas mortales.

La sensación de poca protección en esas partes del cuerpo, puede llegar a crear una incomodidad inconsciente en quien está usando la prenda, pero si esta está hecha muy bien, el diseño será lo que tendrá mayor peso. Esto pudo determinarse gracias a una selección de bocetos de prendas con las características mencionadas a personas reales que mantienen un estilo de moda alternativo.

La figura del libro Necronomicón, como el desencadenante de todas las desgracias, se puede acondicionar muy bien al tipo de estampados que se observan en la marca Killstar, ya que, en numerosas prendas y accesorios, se observan grafías que hacen referencia a libros de hechizos, libros de los recién muertos, libros de pociones, personas a asesinar y libros de invocaciones.

Para los estampados, funcionan muy bien también las figuras de las personas poseídas y de miembros amputados que tienen vida propia.

\section{Incorporación de la sensualidad divertida al terror}

Hasta ahora, se ha hablado del concepto de diversión surgido de las películas de cine de terror serie B, gracias a la utilización de elementos como el humor negro, los efectos especiales sangrientos de bajo presupuesto, y a como los directores supieron jugar con los miedos que tienen en común los seres humanos, para brindarles una experiencia única al observar sus obras cinematográficas.

Es momento de hablar de la sensualidad como hilo conductor de todos los elementos formales del terror, y el miedo que se han encontrado gracias al análisis hecho referente a esos temas. 
A lo largo de la historia se han reconocido iconos de la sensualidad femenina como Cleopatra, Soong Ching Ling y más recientemente Diana, princesa de Gales, mujeres cuya gran belleza podía encontrarse en un físico y en un interior. Una de las principales características que marcó a las mujeres de las que se habla, fue su gran inteligencia para llevar a cabo, y hacer realidad, los proyectos que se proponían. Fue, quizás, esa astucia de líderes, y de querer conocer cada vez más sobre el mundo que las rodeaba, uno de los puntos clave que las hizo tan sensuales para su época, y que hoy en día siguen conservando ese estatus en la sociedad.

Acorde a lo anterior se tienen en cuenta la sensualidad como una cualidad que brota de la actitud y de la aptitud de las mujeres. Entonces, se puede decir que el ser sensual es una virtud que nace a partir de cómo se expresa la persona, no sólo a través de su cuerpo, sino también a través de lo que comunica con esas acciones. Este concepto de sensualidad, creado a partir del comportamiento de figuras históricas, se acopla a uno más moderno que busca apuntar al tipo de usuario al que se dirigen marcas como Killstar.

La sensualidad es una cuestión de actitud, y radica en la forma de ser de la persona, en la forma sutil en la que lleva a cabo movimientos insinuantes pero delicados, y en el misterio que provoca el hecho de que deje elementos a la imaginación. En moda, esto se traduciría al no dejar gran parte de la piel descubierta si se trata de un conjunto de ropa interior, o de un vestido de baño, al contrario, lo que se buscaría es dejar al espectador con ganas de ver más, porque aún ha visto todo.

Para apoyar dicha sensación de misterio, entrarían a ser parte importante del diseño sensual, los elementos formales del miedo y del terror que han logrado identificarse en puntos anteriores. Esto, con el fin de ser un eje central al momento de diseñar, y que a lo largo de todas las prendas se lea un mismo lenguaje coherente que supla la necesidad que se ha estado trabajando en todo el artículo.

\section{Resultados}

Como resultado principal, se encuentra el hecho de que, para el desarrollo de la colección de la que se habló en la introducción, se trabajará el concepto de miedo como protección, no como una emoción negativa del ser humano. El principal miedo que se desarrollará en las prendas, teniendo en cuenta todos los análisis realizados a las películas referentes del cine de terror serie B, será el miedo a lo desconocido y al otro, lo que permitirá hacer uso de bases textiles que se contrasten entre sí por su textura y por su capacidad de generar transparencia y translucidez. 
El elemento del monstruo como causante de temores y pesadillas en los seres humanos se manejará de forma indirecta dentro de las prendas, es decir no necesariamente hay que representar la figura de esta criatura de manera literal en un estampado, puede representarse un rostro monstruoso escondido entre las diferentes piezas que conforman un conjunto de panty y brasier, permitiendo que quien lo observe, juegue un poco con su imaginación para entender que es lo que está observando.

Elementos como el volumen, la cobertura del cuerpo, la doble funcionalidad de las prendas, el envolvimiento, los acordonados y los cortes en las prendas, ubicados en zonas especiales, servirán como hilos conductores para mantener el miedo y el terror como conceptos formales, que afectarán directamente el diseño de la prenda sin necesariamente ser tratados como estampados.

También, servirán para dar toques de misterio y misticismo que enfatizarán el concepto de sensualidad, como el hecho de no mostrar todo y dejar cosas a la imaginación del espectador.

\section{Discusión}

Cada diseñador siente y expresa el terror de forma diferente, de manera que a pesar de estar mostrando esta emoción tan fuerte en una colección no se pierda su ADN y todo mantenga un mismo lenguaje.

"La moda trata de ocultar el horror y abrazar sólo la belleza" fue lo que dijo Raf Simons en la rueda de prensa de su colección ready to wear Primavera - Verano 2018 para Calvin Klein titulada 205W39NYC, en donde plasmó lo que para él es American Horror Story, y la manera en que, películas icónicas de décadas pasadas, siguen influyendo hoy en día. Dentro de la colección, se mostraron siluetas limpias y elegantes inspiradas en la película American Psycho (Harron, 2000), así como prendas que parecían totalmente salpicadas de sangre y que recordaban a The Texas Chainsaw Massacre (Hooper, 1974). Se vieron prendas de un tono azul claro que recordaban el personaje de Mia Farrow en Rosemary's Baby (Polanski, 1968) y serigrafías con imágenes de cuchillos y sillas eléctricas de las obras de Andy Warhol (1928-1987).

La visión del terror que tuvo John Galliano para su colección de Haute Couture Primavera - Verano 2006 para Dior, fue la de la situación de la Revolución Francesa en el siglo xviii. Su principal referencia fueron todas las cabezas guillotinadas de los líderes franceses de la época, que provocaron el decaimiento y sufrimiento de la clase baja y media francesa, dando así la sensación de muerte a través de las prendas que pare- 
cían totalmente llenas de sangre y de un sobrecargo de muerte. Los atuendos fueron creados pensando en una "'nueva María Antonieta' que con Galliano no tendría nada que temer a la guillotina" ya que la función de estos sería resaltar su belleza.

\section{Conclusiones}

Trabajar con un aspecto tan antiguo y temido como es el miedo mismo ha permitido entender mucho más esta emoción, tan mal vista, y a la que se suele evitar a toda costa. El aprendizaje obtenido a partir de los análisis realizados a los aspectos fundamentales del miedo y del terror, y de algunas películas, ha permitido comenzar a llenar un vacío identificado en el mundo de la moda, el terror se muestra en las prendas únicamente a través de estampados sobre lo que se conocen como básicos, dejando así de lado la oportunidad de explorar a nivel de diseño siluetas y materiales que pueden contribuir enormemente a la formalización del terror.

Tener, como punto de inspiración películas de terror serie B, permite también dar a conocer, de forma un poco más amigable, el género del terror a las personas mediante prendas de vestir, ya que al ser un subgénero que utiliza elementos de humor, puede llegar a tener mayor aceptación, incluso por parte de las personas que suelen rechazar todo aquello que les produce miedo. Es también una oportunidad de ofrecer una alternativa de productos a una marca como Killstar que es tan reconocida por sus característicos estampados de figuras demoniacas, ya que, por medio de estampados, que recuerden una década tan importante como los ochenta, pueden llegar a un público mucho más grande que se encuentre movido por las emociones de los recuerdos de su infancia.

\section{Séptimo y octavo semestre}

\section{Línea de investigación: comunicación interactiva}

Se orienta por la relación de sus componentes: desde la comunicación, considerando la lingüística, la semiótica, la información y la interactividad dada por los actores, a través de los medios y las nuevas estrategias de las tecnologías de la información y la comunicación, sin dejar de lado la acción comunicativa individual, la cual genera la comunicación colectiva y social, en lo regional y en terrenos de la globalización. Aspectos que harán comprensible el mundo por la interpretación del entorno desde la perspectiva del ser humano. 


\section{Núcleos problémicos}

» Lenguaje y comunicación visual

$»$ Contenidos digitales

» Interacción en mass media

Séptimo semestre: diseño de autor aplicado al vestuario de gala y novias

Núcleo problémico. Lenguaje y comunicación visual. El diseño como medio narrativo.

Subtema de investigación. Trascender

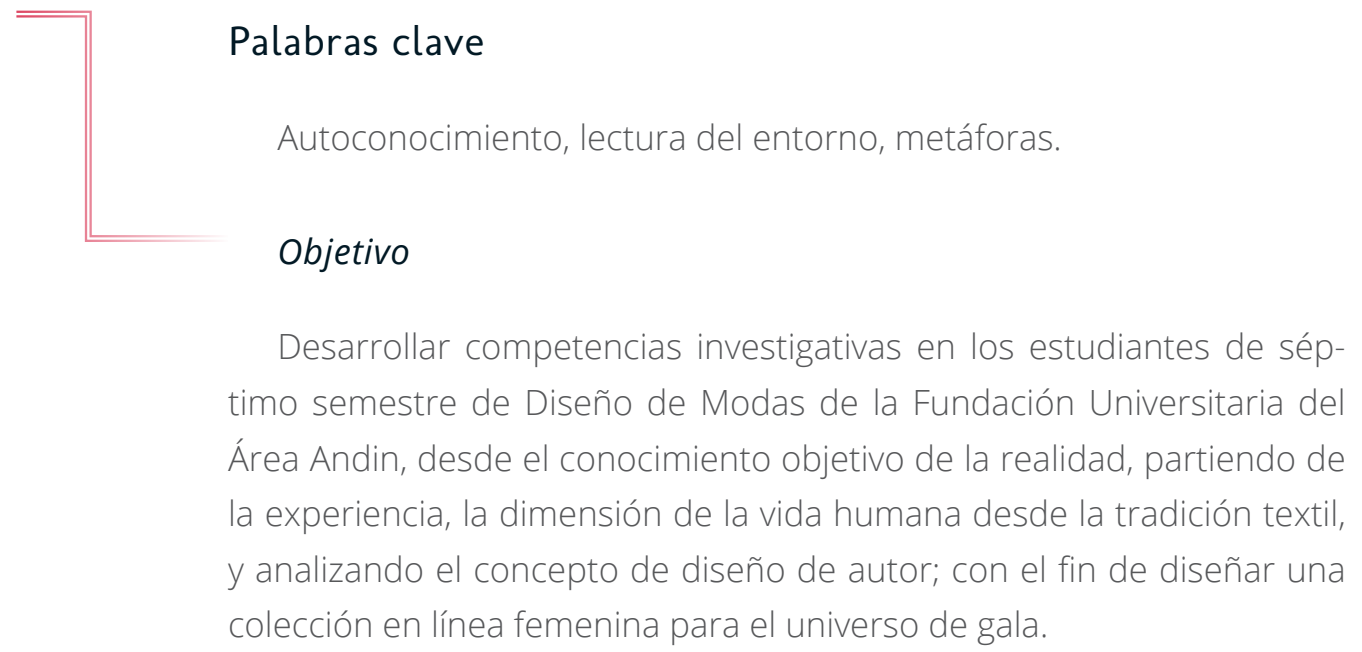

Entregables

» Semana 8

» Artículo de investigación

» Moodboard de concepto

» Bitácora de diseño.

» Un corsé y una prenda inferior en patronaje mágico, que genere volúmenes. 
» Portafolio

» Reseña personal, respondiendo a la pregunta ¿quién soy como diseñador?

» Video personal

» Moodboard de conceptos. Conceptos, referencias de otros diseñadores, insumos, accesorios, usuario, materiales y técnicas utilizadas a lo largo de su aprendizaje. ADN de usted como diseñador

» Ocasión de uso (diseño de experiencia)

» Colección digital (diez diseños novia y gala, delantero y posterior)

» $\quad$ Face chart (propuesta de maquillaje y styling)

» $\quad$ Proceso editorial de moda (fotografía)

» $\quad$ Patronaje digital y tendido (arquitectura) en el software que desee.

\section{Semana 16}

» Página web (WIX).

» Un indumento femenino, gala o novia, y calzado

\section{Bases textiles}

Shantung, piel de ángel, tafetán, satín licrado, guipiur, lamé, organza, toul fantasía, velo chiffón, faya, holán de lino, lino algodón y lino 100\%.

\section{Entregas finales}

Ver figuras de la 31 a la 39. 


\section{FIGURA 31}

DISEÑO DE AUTOR. VESTUARIO DE GALA Y NOVIAS. CAMILA RODRÍGUEZ..
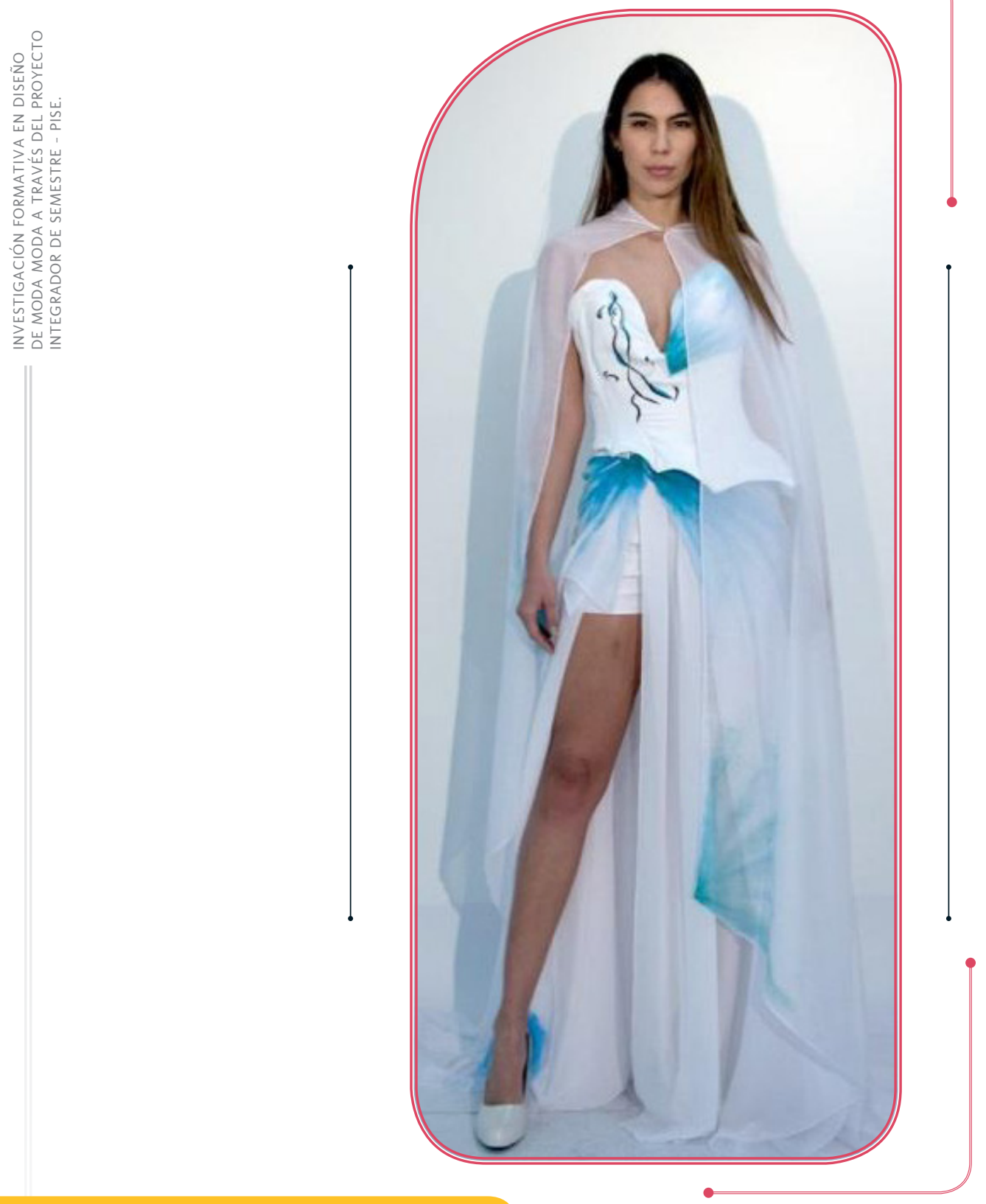

Fuente: Auditorio Fundación Universitaria del Área Andina, sede Bogotá.

Programa de Diseño de Modas León, 2019. 


\section{FIGURA 32}

DISEÑO DE AUTOR. VESTUARIO DE GALA Y NOVIAS. MAYIBE MOLANO.

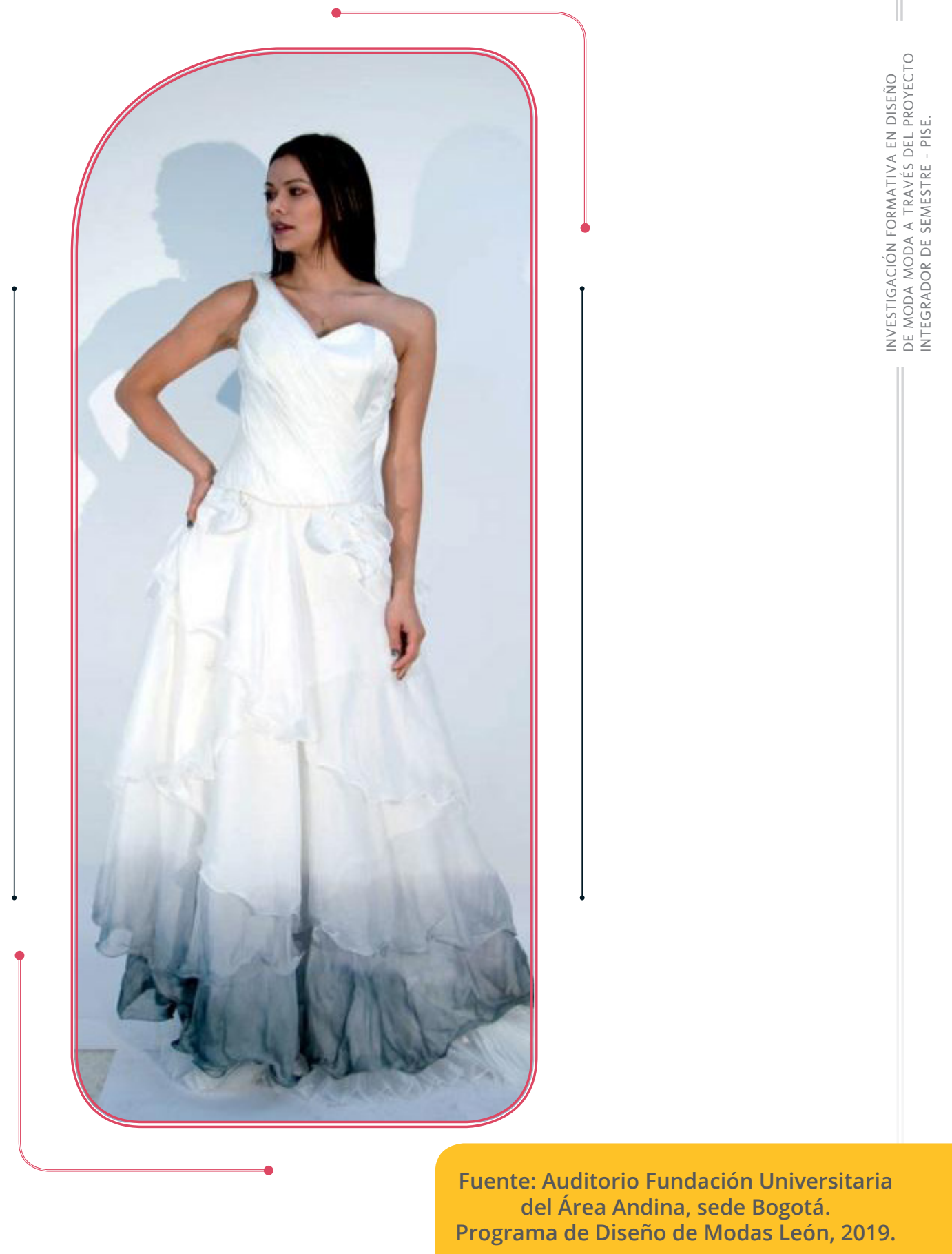




\section{FIGURA 33}

DISEÑO DE AUTOR. VESTUARIO DE GALA Y NOVIAS. XIMENA LUQUE.
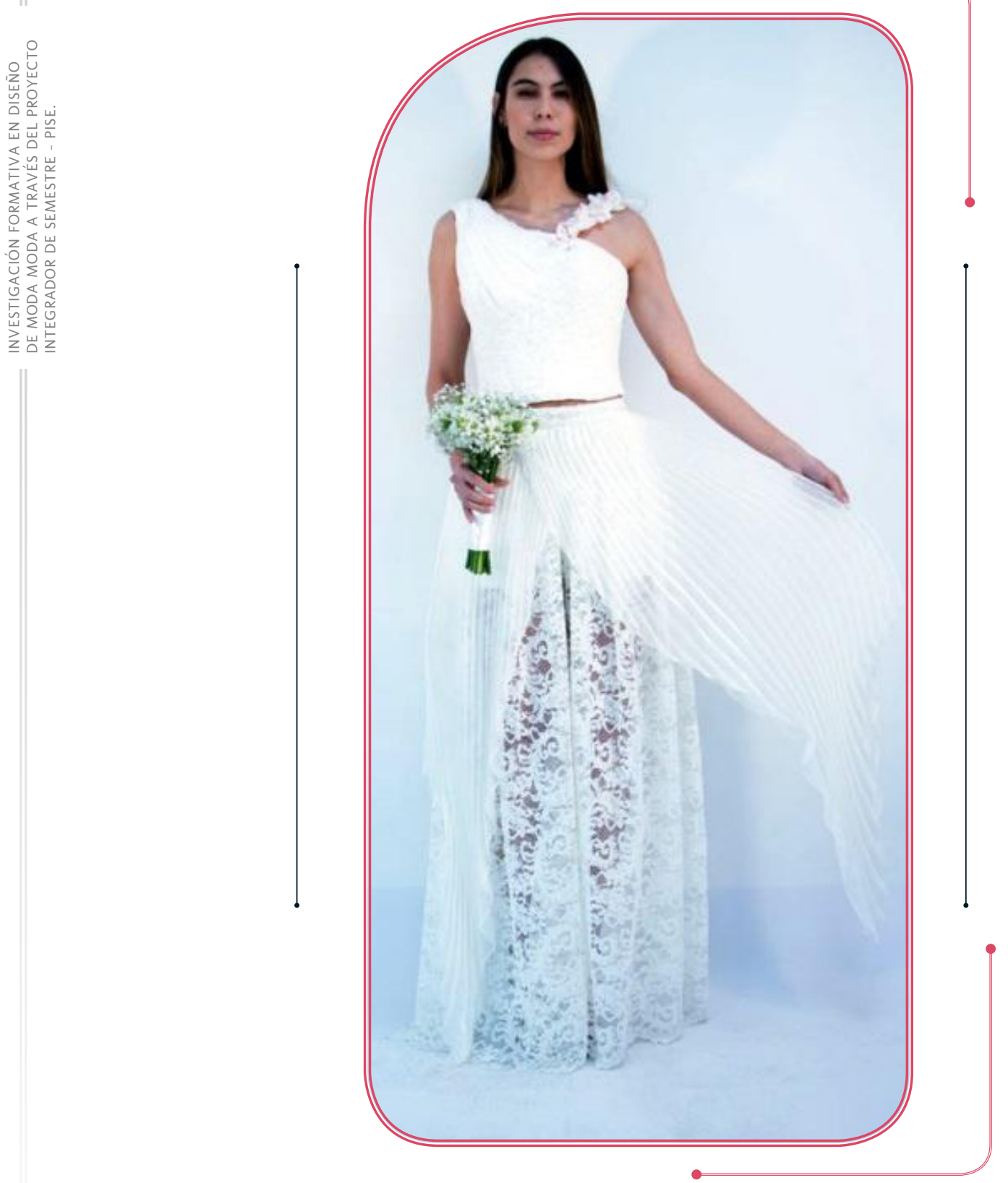

Fuente: Auditorio Fundación Universitaria del Área Andina, sede Bogotá.

Programa de Diseño de Modas León, 2019. 


\section{FIGURA 34}

DISEÑO DE AUTOR. VESTUARIO DE GALA Y NOVIAS. ESTEBAN GUTIÉRREZ.

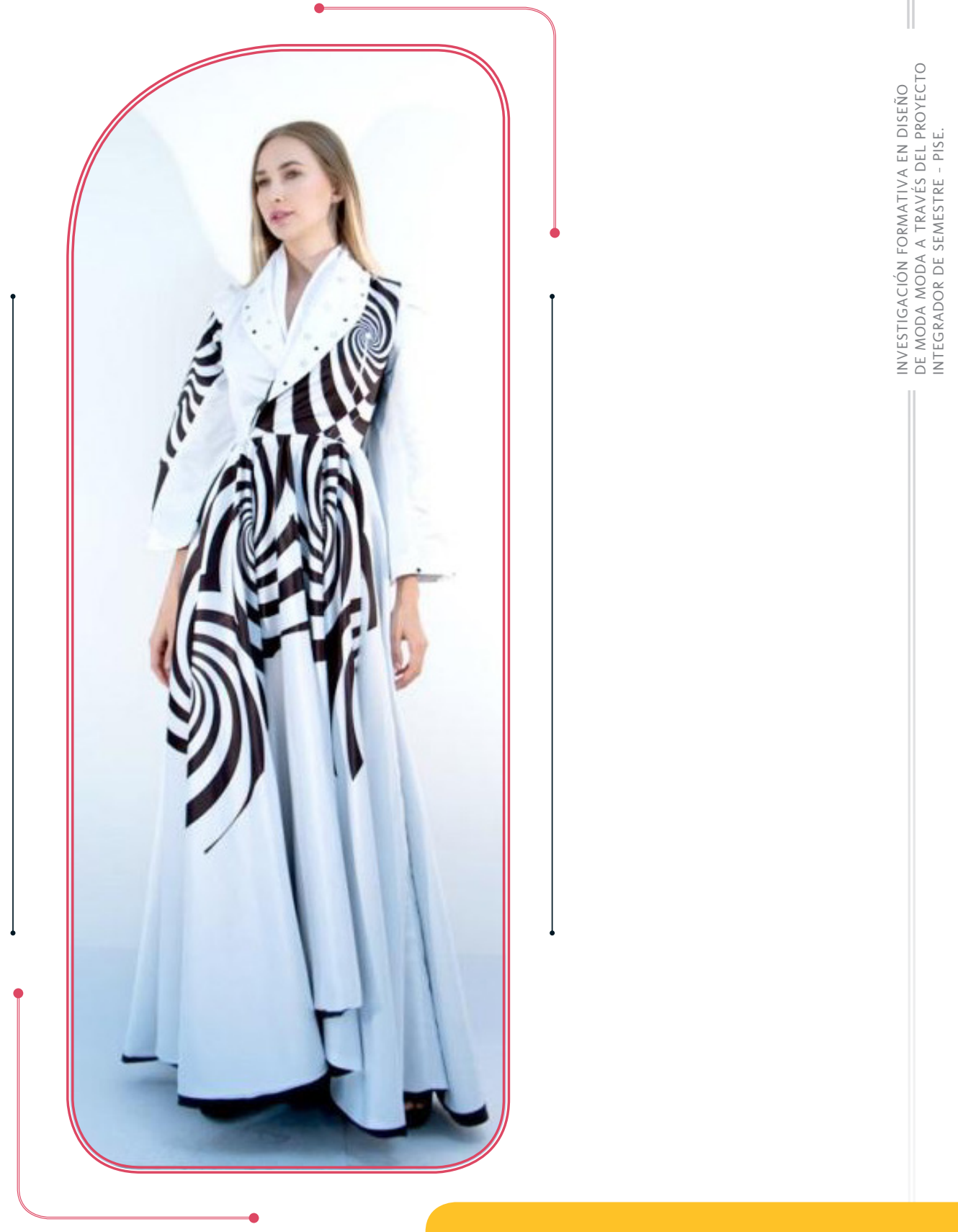

Fuente: Auditorio Fundación Universitaria del Área Andina, sede Bogotá.

Programa de Diseño de Modas León, 2019. 


\section{FIGURA 35}

DISEÑO DE AUTOR. VESTUARIO DE GALA Y NOVIAS. SARA COBOS.
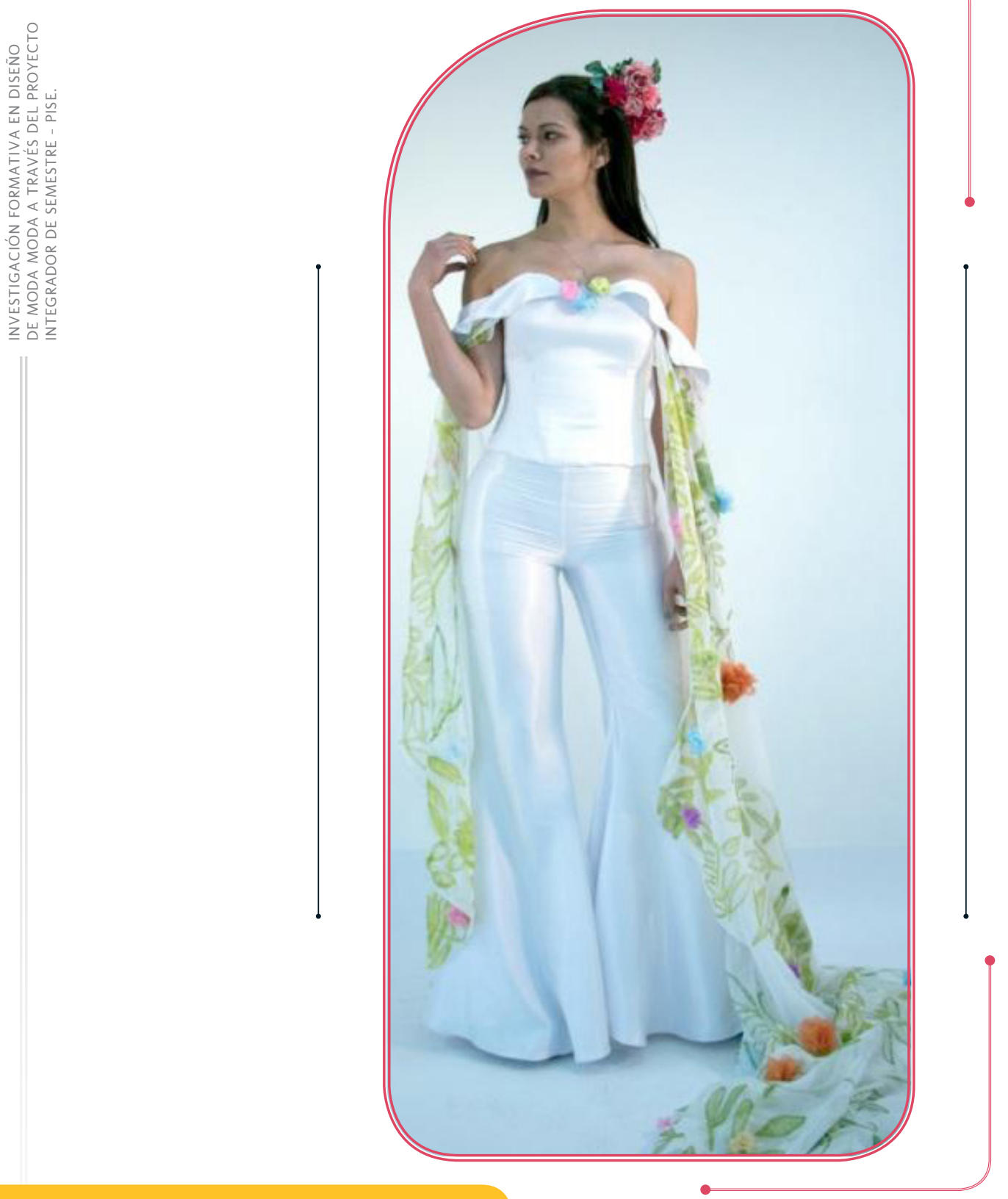

Fuente: Auditorio Fundación Universitaria del Área Andina, sede Bogotá.

Programa de Diseño de Modas León, 2019. 


\section{FIGURA 36}

DISEÑO DE AUTOR. VESTUARIO DE GALA Y NOVIAS. MÓNICA MURILLO.

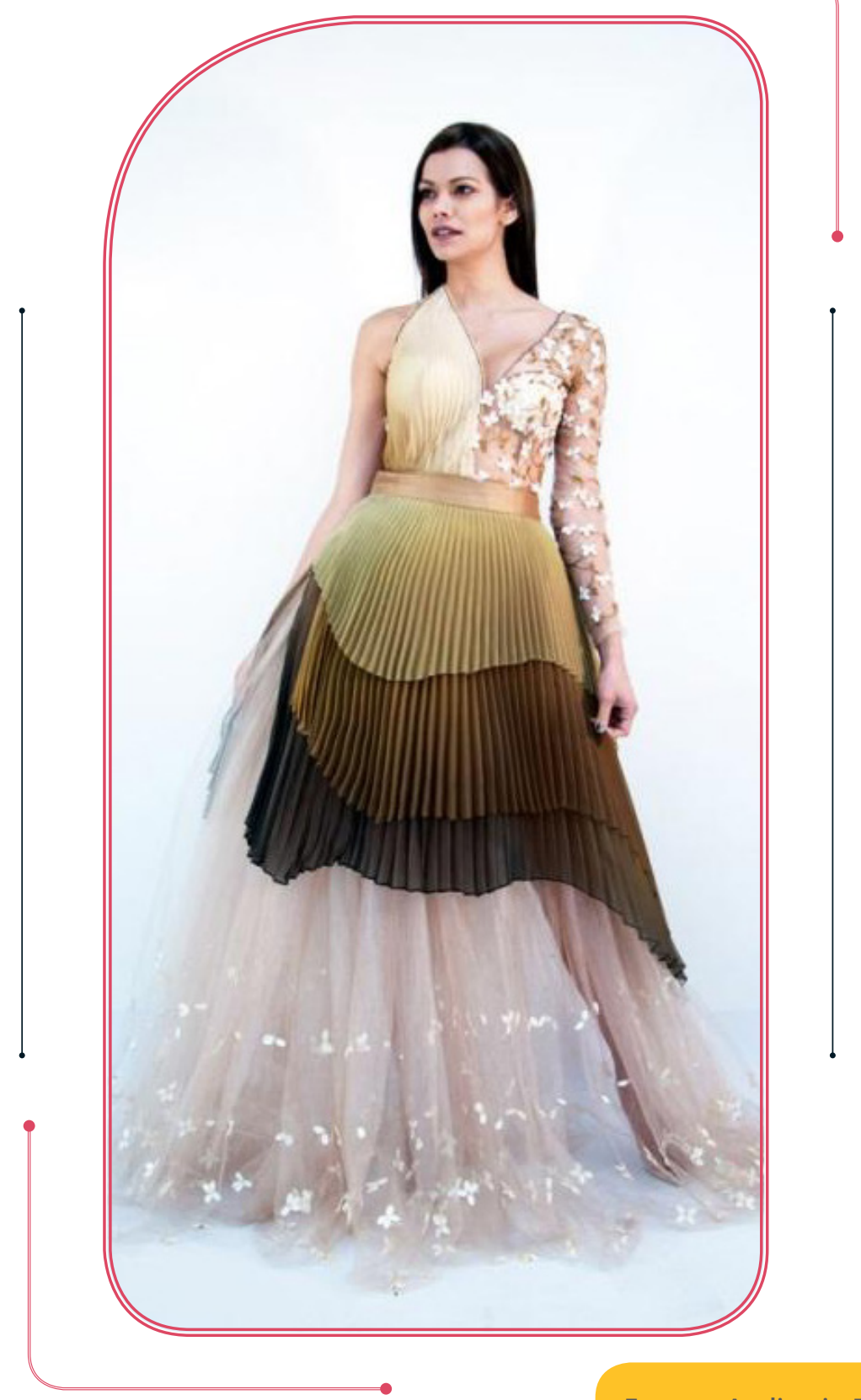

Fuente: Auditorio Fundación Universitaria del Área Andina, sede Bogotá.

Programa de Diseño de Modas León, 2019. 


\section{FIGURA 37}

DISEÑO DE AUTOR. VESTUARIO DE GALA Y NOVIAS.LORENA LAVERDE.
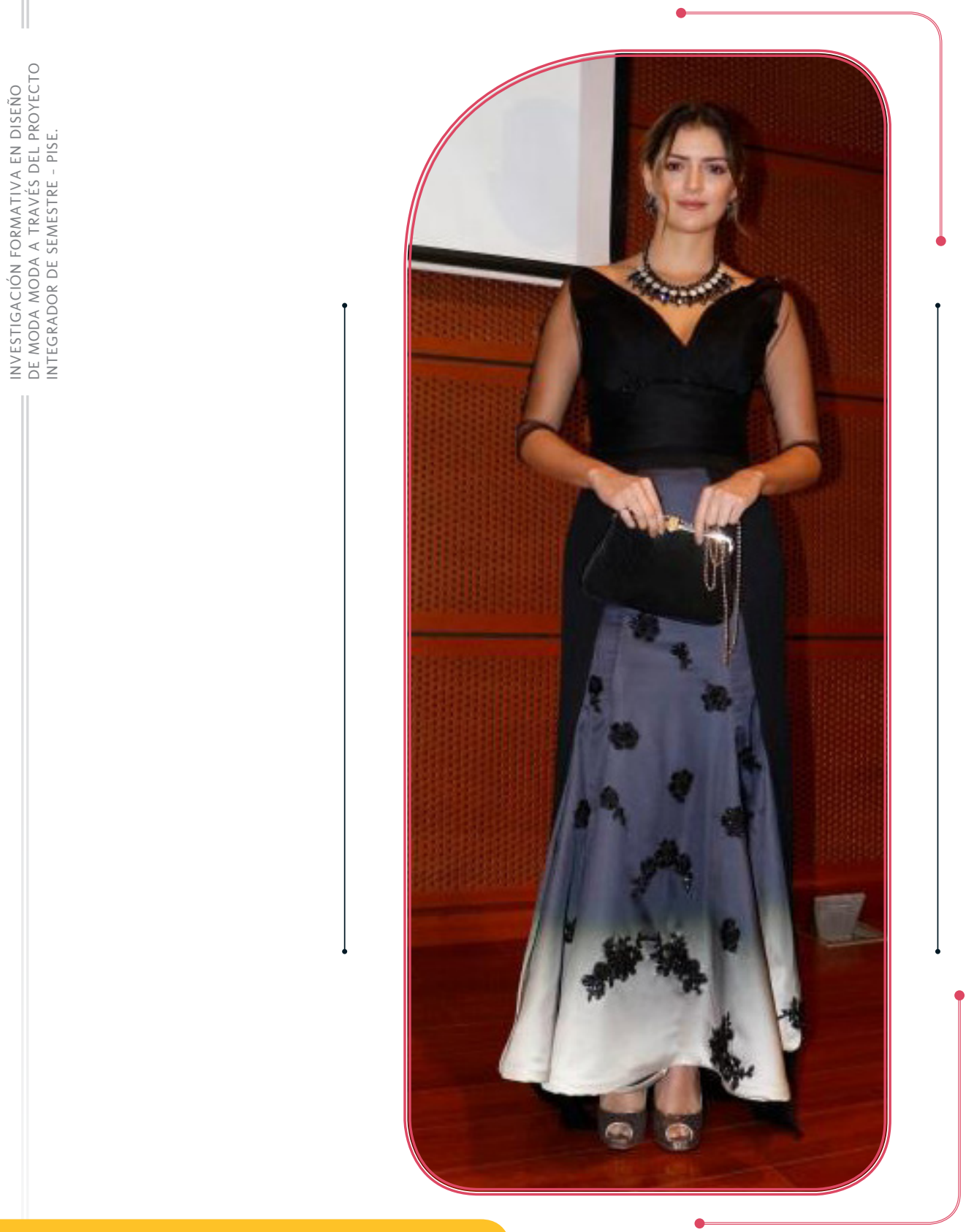

Fuente: Auditorio Fundación Universitaria del Área Andina, sede Bogotá.

Programa de Diseño de Modas Riachi, 2019. 


\section{FIGURA 38}

DISEÑO DE AUTOR VESTUARIO DE GALA Y NOVIAS. ELIZABETH RANGEL.

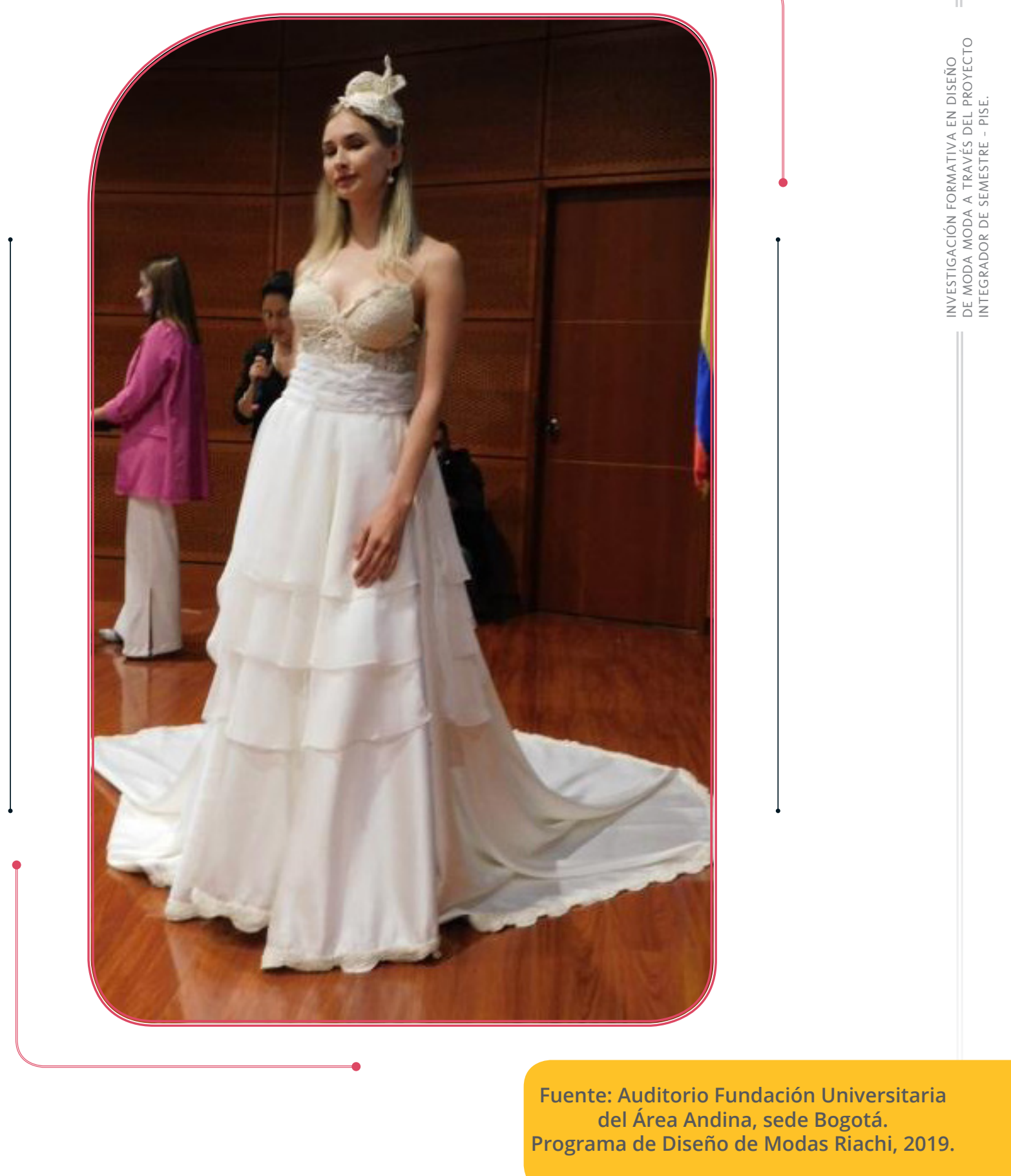




\section{FIGURA 39}

DISEÑO DE AUTOR VESTUARIO DE GALA Y NOVIAS. JUANA RODRÍGUEZ.
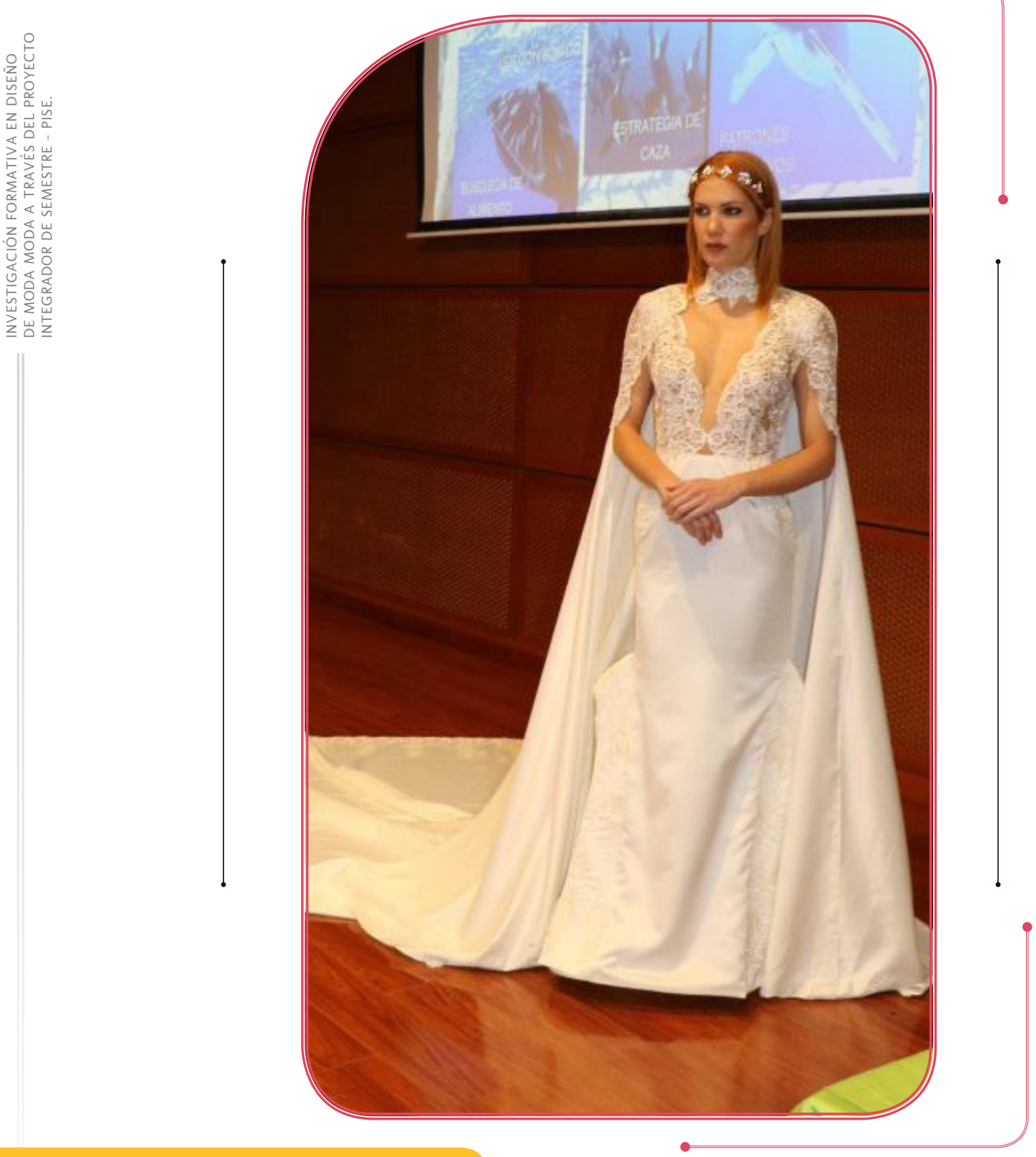

Fuente: Auditorio Fundación Universitaria del Área Andina, sede Bogotá.

Programa de Diseño de Modas Riachi, 2019. 


\section{Artículo resultado final: Colección Abrazo Mágico. Elizabeth Rangel Pinto}

\section{Resumen}

Abrazo Mágico es una colección para la temporada primavera verano 2019 / 2020 del universo gala-novia, maxi-retro. Como Diseño de Autor se hace énfasis en el gusto por el anime que se evidencia en los códigos de diseño que me definen, y el intercambio cultural en Argentina.

Teniendo en cuenta estas características, se realizó una analogía para el desarrollo de la colección, influenciada por la tendencia Secuencia Creativa Primavera / Verano 2019 / 2020 de la WGSN, con siluetas de los años cinquenta, inspirada en el estilo kawaii japonés, con los movimientos del tango en la técnica de ganchillo. Se logró así enfocar esta colección a mujeres profesionales bohemias, de espíritu multicultural y extrovertidas; siendo ideal para las novias, damas de honor y acompañantes que son arriesgadas, elegantes y abiertas a nuevas propuestas.

\section{Palabras clave}

Anime, Argentina, crochet, estilo, kawaii, patrimonio, siluetas, sub-cultura, superficies, técnica, tejido de punto.

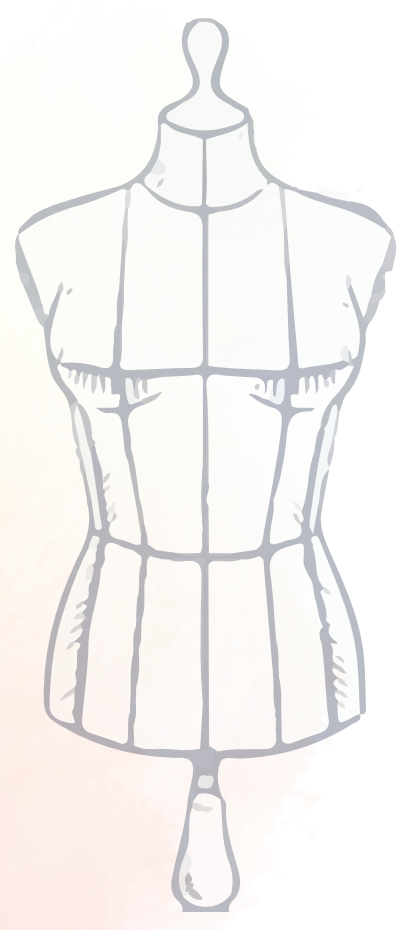

\section{Introducción}

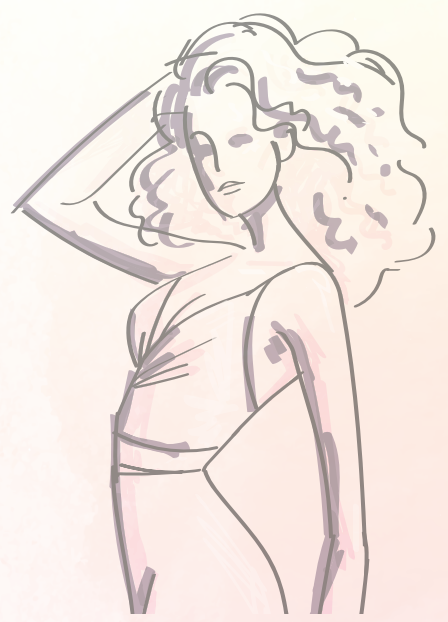

El presente proyecto nace de la necesidad de satisfacer los requerimientos para este semestre el cual plantea elaboraron una colección de diseño de autor que vincule el Conectar Saberes, Arte y Creatividad con el trascender/Punto de Origen.

Para ello se analizaron diseñadores, se les dieron respuestas a preguntas correspondientes al diseño de autor y posteriormente se elaboró mapas mentales, moodboards, y bocetos que dieron respuesta a la colección Abrazo Mágico. 
Se desarrolló una colección que evoca cada una de las vivencias del diseñador a través del paso del tiempo en la vida, contadas con detalles en tejido de crochet, velos, drapeados y volúmenes.

La característica principal de esta colección es ofrecerle, a la usuaria, una nueva forma de vestir con diseños creativos e innovadores de únicas prendas, invitándola a expresarse de formas distintas, sin perder su estilo y uso de ocasión, ofreciendo al usuario piezas con versatilidad para que siempre esté innovando.

\section{Reflexión}

Para comenzar a desarrollar la colección Abrazo Mágico, se inició haciendo una lectura de diseñadores que han sido referentes para la carrera, identificando los códigos de diseño que cada autor lleva en sus colecciones, sacando elementos y palabras claves que los identifican. Los códigos de diseño son aquellos elementos que se combinan para generar una lectura del entorno en cada diseño, como textiles, siluetas, texturas y universos de moda en los cuales se trabajan.

Ya con la información clara, se procedió a analizar nuestros propios códigos de diseño, donde se identificó mi ADN en cada colección, dando, como resultado, diseños que tienen intervención textil, tejidos, cortes asimétricos y simétricos, con sobre posición de prendas, diseños innovadores, arriesgados y coloridos, se manejan texturas visuales y táctiles dados por intervenciones textiles, donde se defiende la tradición del tejido en ganchillo, el diseño diverso y un estilo kawaii.

Me defino como una diseñadora innovadora, arriesgada que maneja diferentes técnicas en la construcción de prendas y accesorios para un público extrovertido, arriesgado, neotradicional y elegante. Encuentro también ese sentido de pertenencia con cada cosa que se hace, siempre pensando en las consecuencias de nuestros actos, y procurando producir con conciencia ambiental ya que, no solo se piensa en el uso momentáneo, sino que también en qué va a pasar después de ello, buscando diferentes usos o de construyendo las mismas piezas para encontrar un nuevo uso, dentro de los diseños elaborados anteriormente se hizo intervención con tejidos en dos agujas, crochet o tejido de punto en máquina tradicional.

Se usó un estilo versátil en las superficies y siluetas, generando texturas visuales y táctiles que juegan con las trasparencias, además de fusionar gradaciones en formas y contrastes de color entre las piezas. En el proceso de formación se utilizaron referentes de diseño, diseñadores, artistas, lugares y técnicas que han ayudado a centrar y 
aterrizar las ideas para llevar a cabo, hallando otro punto de vista y dando un trasfondo que relaciona el diseño con la presentación de una estética que comunica a través de los sentidos.

Para este último proyecto, se fusionaron tres temas que se hilan uno con otro para desarrollar una colección con transcendencia de los pasos durante la infancia, atravesando por la juventud, hasta llegar a la madurez, la cual demuestra que, con el tiempo, nuestros propósitos y sueños se pueden cumplir.

Comienzo con el gusto por el tejido de punto, dado que se aprendió en sus tres técnicas y que han sido un legado durante dos generaciones en mi hogar, comenzando con los trabajos que desarrolló mi abuela, pasando ese conocimiento a mi madre, quien lo aprendió en su adolescencia, ejerciendo la labor aún por gusto a sus 68 años de edad, y que desde niña he mostrado interés por este arte, para aplicarlo así en esta colección, usando puntadas redondeadas en las superficies de la misma.

La historia de la técnica del tejido a mano, llamado crochet; que etimológicamente viene del francés crochet, compuesta por croc, que significa hierro curvado, y el sufijo diminutivo et, comprende que es ganchillo o labor de gancho, (Etimologías de Chile, 2001), y consiste en tejer cadenas anudadas de cualquier material en línea continua, utilizando una aguja que lleva, en uno de sus extremos, un garfio que sostiene la línea a tejer. También se puede realizar este tejido con los dedos.

Mucho se habla del origen inexacto de la técnica del crochet, hay datos que indican que este arte viene del siglo iv de nuestra era. Pero que también se han encontrado piezas como medias elaboradas en varias agujas de doble punta en algodón en Egipto en el siglo v, hay muchos otros vestigios en Israel y Perú, existe otra teoría que indica que nació en el Norte de África hacia los comienzos de la era cristiana, y que se extendió luego por Europa con la ruta comercial de los árabes, pero ciertamente no han podido definir cuál es la antigüedad de la técnica, lo que sí se puede deducir es que todas manejaban los mismas grafías como los círculos, cruses, cuadrados y líneas curvas que para ellos significaban el tiempo, los cuatro puntos cardinales, la caza, la Iluvia y el viento (Martinez, 2016).

Más adelante en el siglo xv, en Europa se convirtió en una industria importante, ya que los bordados se hacían con hilos muy finos y era llamada ganchillo tambour francés o de tambor, ya que se elaboraba la técnica con ayuda de bastidores, y para mitad del siglo xvii se quitó el bastidor y se comenzó a utilizar la técnica al aire tal y como la conocemos ahora. Está técnica se inició como una práctica artesanal, sirviendo como un apoyo económico en algunos asentamientos para cuando los recursos económicos 
no eran abundantes para comprar bordados y encajes finos. Los productos tejidos en esta técnica artesanal eran adquiridos por personas de clase media o por personas que querían pretender pertenecer a la alta sociedad.

Se ha hallado un descubrimiento que ha dejado atónitos a muchas personas respecto a la técnica devaluada por la clase alta y es que la Reina Victoria fue una de las pioneras en apaciguar la mala imagen de la técnica, ya que a ella le gustaba este arte y compraba encajes que realizaban artesanos irlandeses y que con el tiempo aprendió a realizar el tejido al crochet ella misma.(Tejidos al Crochet, 2011)

Una de las razones que hacen que la técnica haya sobrevivido a la industria, es por el aumento de la alfabetización de las mujeres tejedoras las cuales se encargaron de elaborar libros y revista de patrones con la técnica.(Martinez, 2016). Durante el siglo xx, en las casas de alta costura como la de la diseñadora de modas Elsa Schiaparelli, se ideó la forma de emplear los talentos y conocimientos de las mujeres tejedoras del arte a crochet, diseñando su famoso suéter trompe l'oeil en 1920, el cual tuvo tanto éxito que a la mujer que le encargó su diseño le tocó emplear a más tejedoras por la gran demanda que este producto obtuvo.

Debido a lo anterior se creó en 1947 el Women's Home Industries (WHI), empresa que hacía canjes de materiales y patrones por producto terminado a la comunidad de mujeres de hogar perteneciente a Women's Voluntary Services (WVS) durante la Segunda Guerra Mundial, haciendo de esta una filial para trabajar con casa de alta costura como la de Schiaparelli y Christian Dior, y durante las siguientes dos décadas surtió de ropa de alta calidad tejida a mano a tiendas como Neiman Marcus, en DaHas, y a clientes privados, algunos de ellos celebridades como Lauren Bacan o la princesa Margarita de Inglaterra (Black, 2012).

En la actualidad tenemos diferentes diseñadores que manejan las técnicas del tejido artesanal crochet en sus diseños de ropa casual y de alta modas, dentro de ellos tenemos a uno de mis diseñadores referentes, el diseñador Tadashi Shoji, quien dice "Cada mujer, independientemente de su tamaño y forma, merece sentirse segura, cómoda y hermosa". (Shoji.com, 2019), Tadashi Shoji es un diseñador de moda japonés establecido en Estados Unidos, él es reconocido por crear vestidos de noche y vestidos de alfombra roja para mujeres. Su estilo es artesanal, elegante y geométrico que inspira a las mujeres reales, a sentirse seguras y cómodas con lo que llevan, por ello es uno de mis diseñadores referentes ya que en mi colección rescato la estética al pertenecer a un grupo de mujeres de baja estatura, delgada y ya adulta y quiero reflejar que mis diseños son inclusivos tanto para modelos como para gente real como yo. 
Continuando con el segundo punto de inspiración para la colección Abrazo Mágico, encontramos mi gusto por el anime japonés, el cual surgió cuando era muy niña al ver dibujos animados por televisión por cable en compañía de mis tres hermanos, animes que me cautivaron por sus historias, indumentaria, accesorios, colores e ilustraciones. Series como Sailor Moon, Súper campeones, Caballeros del Zodiaco, etc, son influencias que marcaron toda mi infancia y parte de mi adolescencia, y que ahora se ha convertido en una de mis pasiones cuando estoy en tiempo de ocio.

El anime (प्र०), es una palabra de origen francés que significa animado o vivo, en 1985 el termino fue adoptando por los japoneses para referirse a la producción de dibujos animados o caricaturas para televisión, la palabra también engloba a las producciones hechas directamente para DVD Ilamadas OVA u OAV (original animation video) y películas animadas para cine (Cobos, 2001).

Este género de animación data del siglo XX, que ese entonces eran cortos animados de dos minutos los cuales eran similares a la animación de países como Estados Unidos, Rusia, Alemania, Francia, entre otros. El primer cortometraje fue Namakura Gatana de Junichi Kouchi, en el año de 1907 (Montoya, 2019).

En la década de 1930, esta forma de animación se convirtió en una narrativa de cuentos ya que al no poder utilizar actores reales en un mundo de fantasía era imposible, permitió a los artistas crear personajes, indumentaria, historias y entornos por medio de la animación.

Para la década de 1970, se aumenta la popularidad de los mangas que significa "imagen caprichosa" (comic japonés impreso), los cuales van a pasar a ser animes, uno de los escritores del manga fue Ozsamu Tezuka que ha sido denominado como el "dios del Manga" creador de Astroboy (Bendazzi, 2003). Para la época de los años treinta y cuarenta la animación japonesa pasó por muchos cambios, dejando de lado los cuentos por historias de tipo occidental, y se comenzó a emitir el anime Norakuro (1934) de Mituyo Seo, siendo esta una de las primeras adaptaciones del manga al anime, y durante la segunda guerra mundial las animaciones se convirtieron en propagandas de guerra (Montoya, 2019).

Para la década de 1990 a 2000, el éxito de las animaciones japonesas y adaptaciones en el idioma se produjo un gran auge en el exterior por lo cual se hicieron traducciones al español, dentro de estos años surgen series como Dragon Ball, basado en el manga de Akira Toriyama; Saint Seiya conocida también como Los Caballeros del Zodiaco, Capitán Tsubasa, conocida en nuestro país como Súper campeones; Rurouni Kenshin, con el nombre en América como Samurái X, Neon Genesis Evangelion de Hi- 
deaki Anno; Pokémon, Ranma 1², y Sakura Card Captor, entre otros. (Montoya, 2019). El anime tiene diferentes géneros como:

» Mecha: que son aquellos que tratan temas de robots gigantes y alta tecnología. (Neon Genesis Evangelion de Hideaki Anno)

» El magical girls: que tratan de historias de fantasía donde la o las protagonistas tienen poderes mágicos. (Las Guerreras Mágicas de CLAM)

» Cyberpunk: que son historias que se desarrollan en un mundo oscuro y devastado. (La serie de experimentos Lain de Chiaki J. Konaka)

» Harem: el cual los protagonistas son un hombre en un grupo de mujeres o viceversa, una mujer en un grupo de hombres. (Saber Marionette de Satoru Akahori)

» Ecchi: se trata de humor con toques eróticos. (B Gata H Kei de Shueisha)

» Kodomo: son dirigido a niños con ellos y mascotas como protagonistas. (Digimon de Akiyoshi Hongō)

Hay otras animaciones que tienen un alto contenido, hacen parte del anime y del manga:

» Gore: Son aquellos animes que tratan temas sangrientos y violentos (Helsin).

» Hentai: tratan temas sexualmente explícitos, heterosexuales (Okusama wa Moto Yariman).

»Yaoi: Son animes con romance entre hombres, pueden ser o no sexualmente explícitos (Junjou Romantica).

» Yuri: Tratan temas de romance entre mujeres, pueden ser o no sexualmente explícitos (Ro-Kyu-Bu).

En la actualidad existen numerosas series, ovas y películas por año, llegando a ser una de las industrias más fuertes en el mundo de la animación; teniendo paginas propias de divulgación de episodios nuevos, entre las personas más destacadas de esta industria esta Hayao Miyazaki, fundador del Studio Ghibli, quienes realizaron las famosas películas de Mi vecino Totoro, El increíble castillo vagabundo, El viaje de Chihiro, y Ponyo, entre otras. (Montoya, 2019). 
Dentro de todo este mundo existe un estilo llamado kawaii, la cual es la palabra japonesa que engloba todo lo 'tierno' pero dentro de "bonito" por su estética colorida, tierna, e inofensiva. El termino fue inicialmente utilizado para denominar a los bebes y niños jóvenes, después de los sesenta se comenzó a utilizar para ciertos peluches y muñecas japonesas, apropiando este término por personas adolescentes, jóvenes y adultas.

Para estos instantes el término kawaii ya se ha convertido en una subcultura japonesa, la cual es muy popular entre los jóvenes occidentales, definido como una forma de pensar y ser, dada por lo infantil y las excentricidades de un mundo rosa y suave que surge como un refugio de la sociedad actual, el competitivo mercado laboral y demás presiones a las que se enfrentan la juventud japonesa. Esta estética se ha extendido por todo el mundo en zonas como Latinoamérica, Europa y los Estados Unidos (Sephora, 2011).

Una persona amante del kawaii usa colores pastel los cuales son los más destacados dentro de esta moda, acompañados de las poses tiernas y adorables que las personas que la siguen hacen en todo momento. Las japonesas tienen en mente un estilo de pureza e inocencia que combinan con una apariencia completamente de muñecas. (Sugoihunter.com, 2016).

Dentro de los accesorios que utilizan encontramos juguetes, peluches, muñecas, dulces, personajes de dibujos animados, animales, aretes, bolsos, mochilas, medias con distintas formas, fundas para el celular y el cargador, diademas, lazos para el pelo, pulseras y zapatos con colores pasteles de diferentes textiles, con toques de alas u orejas de gato, perlas, brillos y hasta cuernos de unicornios.

Finalmente el último punto de inspiración vino a mí, con la oportunidad de viajar a un país que toda la vida quise visitar, conocer y aprender el bello baile del abrazo mágico, el Tango, por el cual me interese al ver bailes en concursos que veía por televisión cuando era adolescente y produce en mí una pasión infinita al escuchar los sonidos del compás que marca el bandoneón con el piano en la música, con el intercambio académico el cual pude tomar, para así ir al país de origen del baile y aprenderlo de personas que llevan años inmersos en este mundo apasionante, los cuales indican que al entrar en el mundo del tango no volverás a salir.

La historia de la danza del abrazo mágico, del juego entre dos cuerpos, el baile típico de Argentina, el tango, llego como una forma de expresión ante una situación de inseguridad, frustración, nostalgia y la falta de una familia dada por la situación a la cual llego el país de Argentina en el siglo xix en las orillas de Buenos Aires cerca al Rio de la Plata, con la gran migración de personas provenientes de países como España, Italia y África. 
El baile del tango tiene sus orígenes en la mezcla de ritmos entre los europeos y la pampa, ritmos que eran bailados por las clases menos favorecidas entre los gauchos y los inmigrantes, era un baile pecaminoso y prohibido, por lo cual eran practicados en prostíbulos, hay archivos que dicen que estos ritmos tenían instrumentos como la guitarra, violines y flautas, o en vez de guitarras usaban arpas; más tarde se comenzó a usar el bandoneón y el piano colocando este un toque nómada entre los tangueros.

La mala fama de este baile se popularizó hasta llegar a Europa, exactamente en París, quienes aportaron el estilo elegante y sofisticado por el cual se comenzó a ser aceptado en Argentina por las clases medias y llevadas después a contratar profesores en secreto de la danza a mujeres y algunos hombres en las clases altas, ya que solo era bailado por parejas de hombres, desapareciendo por completo los orígenes turbios del tango, naciendo así las milongas, lugares o salones de baile donde se podía ir a practicar y socializar.

Para 1830 el tango ya era un baile popular y masivo, sin movimientos quebrados y partidos imponiéndose entre las sociedades sin discriminación en edades y clases sociales. Sus letras eran poesía culta y expresión popular, dado que en sus inicios eran por los payadores quienes eran los cantadores populares que llevaban una guitarra dando mensajes de optimismo y alegría.

Con los arreglos musicales del escritor Pascual Contursi en 1917 añadió letra a la música y se dio el llamado tango canción con el tango "Mi noche triste" interpretado por ese entonces por el dúo entre el reconocido cantante Carlos Gardel y José Razzano, dando así un vuelco a la forma de tocar y cantar el tango.

En 1935 muere Carlos Gardel en un accidente aéreo en Medellín, Colombia, convirtiéndose en el máximo exponente del tango argentino. (Gallo, 2011)

El baile del tango es un estilo misterioso que apasiona a todo el mundo, la sensual combinación entre una mujer y un hombre, en un abrazo mágico, estimula la admiración y curiosidad del público por su enigmática forma de bailar y sentir los tangos; según (Shifres, 2012).

El tango, el estilo de ejecución incide en las posibilidades de sincronización de la pareja, entre otras cosas, porque el gusto por un determinado estilo es condición de posibilidad del encuentro intersubjetivo en la danza.

El estilo de ejecución musical se releja en el estilo personal de danza. El movimiento y sus particularidades personales pasan también a ser rasgos del estilo musical.

Este baile se hace a través del compás 2x4, habiendo dos formas de bailar las cua- 
les tienen diferentes técnicas, la primera es caminando en sentido antihorario, donde se hacen pasos sencillos como el ocho adelante $o$ atrás, algunos adornos y figuras. Y el otro consta del tango con figuras donde el abrazo es abierto, menos apasionante por los sonidos de la música, y más preocupado por lo que pasa en el exterior, es más vistoso y espectacular por lo que solo los profesionales llegan a la máxima expresión de este, convirtiéndose en el tango de espectáculo.

El abrazo mutuo es la primera medida que marca el baile, extendiendo el otro brazo para cerrar las siluetas, una mirada seductora invita a la pareja a iniciar el baile, juntando pecho con pecho y caderas levemente separadas, el hombre aprieta fuertemente a la mujer y comienza a marcar la entrada de los pasos a la dama, en tanto que ella se prepara para seducir.

El paso por el cual la mayoría de los bailes comienzan, se describe de la siguiente manera, según Carballo (2018):

El pie derecho del hombre y el izquierdo de la mujer se mueven primero, el hombre da un paso hacia atrás y la mujer solo lo sigue con su izquierda. segundo movimiento es juntar ambos pies en un mismo lugar. El tercer movimiento es con el pie izquierdo del hombre y el derecho de la mujer abriéndose hacia la izquierda del hombre, y el cuarto es juntando de nuevo los pies en el mismo lugar. Para este momento se debe haber realizado un trayecto con forma de L invertida. En el quinto paso. El hombre avanza con su pierna derecha hacia su diagonal izquierda, dejando las piernas de la mujer de su lado derecho.

La mujer se deja llevar moviendo su pierna derecha atrás. Después, en el sexto paso, los pies del hombre se juntan y los pies de la mujer se juntan cruzando su pierna izquierda sobre su derecha.

En conclusión, el tango, es sinónimo de pasión, donde nunca hay un movimiento erróneo o aburrido, es un sentimiento que tienes que vivir para entender el misticismo que hay entre el dialogo de los movimientos entrelazados que acarician el piso, y las tonadas de cada tango, donde sientes el deseo de continuar bailando y escuchando los melodiosos sonidos del piano y el bandoneón.

Para el año 2.000, se lanza fusiones de sintetizadores, y DJ, para invitar a los jóvenes que continúen el legado del tango, formando así un nuevo producto llamado electro-tango, para darle un nuevo aire a la danza se hacen coreografías donde se elimina paulatinamente el arrastre de los pies en el piso; actualmente los precursores de este género es el grupo Bajo Fondo, Tango Club, Gotan Proyect, Tanghetto. 
Para el 2009 este baile fue declarado por la Unesco, Patrimonio Cultural Inmaterial de la Humanidad (Unesco, 2009).

Siguiendo con la investigación ya para conectar saberes Arte y Creatividad, se tomó la macrotendencia Secuencia Creativa, hallada en (WGSN, 2019) PN 2019-2020, la cual nos sugiere que:

< Inicio de cita>Puesto que el consumismo consciente continúa ganando terreno, las nuevas tecnologías de personalización atenderán la necesidad de unos diseños "mejores, que no más nuevos", con productos que están diseñados para responder a nuestras necesidades de forma exacta y, por tanto, durar más.

Los productos precisos responderán a la necesidad de diseño personalizado sostenible, porque una talla única nunca ha servido para todos. <Fin de cita>

Por consiguiente, se elaboraron diseños que se ajustaran a la silueta de cada cliente, resaltando las cualidades del individuo haciéndolas sentir cómodas y seguras con lo que usan.

También nos habla de (WGSN, 2019) “Nuestro objetivo es diseñar cosas que la gente quiera conservar". Por lo tanto se ajusta a lo que quise elaborar, con el diseño de piezas sueltas que son funcionales en cualquier tipo de evento social al que se quiera asistir, brindando versatilidad al usuario para tener libertad de fusionar las piezas, promoviendo el uso constante de cada combinación que se puede realizar con los elemento, invitando al cliente a conservar cada pieza.

\section{Resultado}

Para lograr resultado obtenido para la elaboración del tejido a crochet de la colección Abrazo Mágico inicialmente se buscó el material que se quería, el cual el hilo para crochet color crema y que además tuviera entre sus hilos una hebra en lurex, haciendo una selección de proveedores que tuvieran ese hilo fantasía que se ajustaba, para luego elaborar varias muestras de crochet en el corsé y en la falda interior del indumento, que se ajustaran a lo propuesto, resolviendo así una puntada a base de abanicos y semicírculos los cuales tienen el ritmo que marca uno de los puntos de inspiración.

Con todo lo anterior la colección Abrazo Mágico propone siluetas de los años cincuenta, que juegan con el volumen y las texturas táctiles y visuales brindadas por los textiles, con constante de color entre crema, champagne, dorado, beige y piel, para 
vestidos de novia y verdes, rojos, rosados y azules para vestidos de gala, obteniendo piezas que dan respuesta a indumentos que resaltan una mujer elegante y compleja, con la característica de ser sensuales, elegantes y atrevidas, con un perfil ecléctico en un universo de gala-novias.

Se utilizó materiales fantasía como shantung, Velo Suizo, pedrería, hilo nylon trasparente y hilo fantasía.

En cuanto a los aspectos formales encontramos líneas orgánicas, la repetición y gradación de tamaño así como la sobre posición y el contraste de texturas, las cuales se ven reflejadas en las siluetas, sobrepuestos y pasamanería.

Para los aspectos funcionales se resalta la exageración de las formas y los volúmenes; Puntada en crochet que evoca los pasos principales del tango buscando representarlos en las superficies. Volúmenes logrados a través del drapeado, la delicadeza y movimiento que evocan el estilo tierno y delicado del anime.

Para finalizar encontramos los aspectos comunicativos que se quiere transmitir es el diseño arriesgado, extrovertido y elegante, con detalles en tejido de crochet, velos, drapeados y volúmenes. Es una propuesta de diseño sostenible y sustentable ya que se puede utilizar en diferentes ocasiones por la versatilidad de las prendas que componen la colección.

\section{Conclusión}

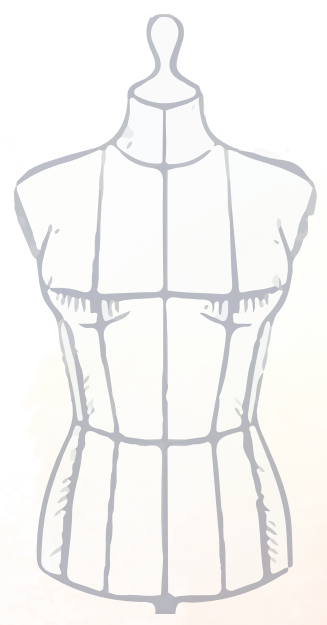

Esta colección es una muestra de la dedicación y la pasión que se puede llegar a tener por su profesión, despertando en uno el gusto por el diseño desde varios puntos de vista, ya sea en ilustración, diseño o confección, encaminándonos en cada una de las ramas en el que nos podemos desenvolver en este medio, dándonos como estudiantes una motivación en lo que hacemos. 


\section{Octavo semestre: diseño de marca}

\section{Núcleo problémico. Contenidos digitales e Interacción en mass media.}

\section{Objetivo}

Desarrollar competencias investigativas en los estudiantes de octavo semestre de Diseño de Modas en la Fundación Universitaria del Área Andina, sede Bogotá, para la toma de decisiones frente a la construcción y posicionamiento de una marca, branding, a partir del análisis y una acción coordinada con el consumidor, identificando las oportunidades y amenazas de las nuevas ideas de negocio, junto a las fortalezas y debilidades internas, proponiendo alternativas estratégicas para introducirse y crecer en el mercado; entendiendo las vinculaciones y repercusiones de las decisiones empresariales entre las diversas áreas funcionales requeridas para una empresa.

\section{Entregables}

» Marca (branding, manual de identidad corporativa)

» Render, video de la tienda física y ficha técnica

» Colección digital, brochure de producto

» $\quad$ Estrategias marketing mix

» Costos iniciales y para el funcionamiento de la empresa, producción, precio de venta y costeo de estrategias

» WIX de la marca

» $\quad$ Presentación digital de propuesta de marca

Como producto final, 50 atuendos fueron seleccionados para participar en la pasarela de Colombiamoda de la Fundación Universitaria del Área Andina, el 25 de julio del 2019, en la ciudad de Medellín, en Plaza Mayor, a la que asistieron alumnos, docentes, directivas de la institución, familiares, invitados y amigos. 


\section{FIGURA 40}

INVITACIÓN.

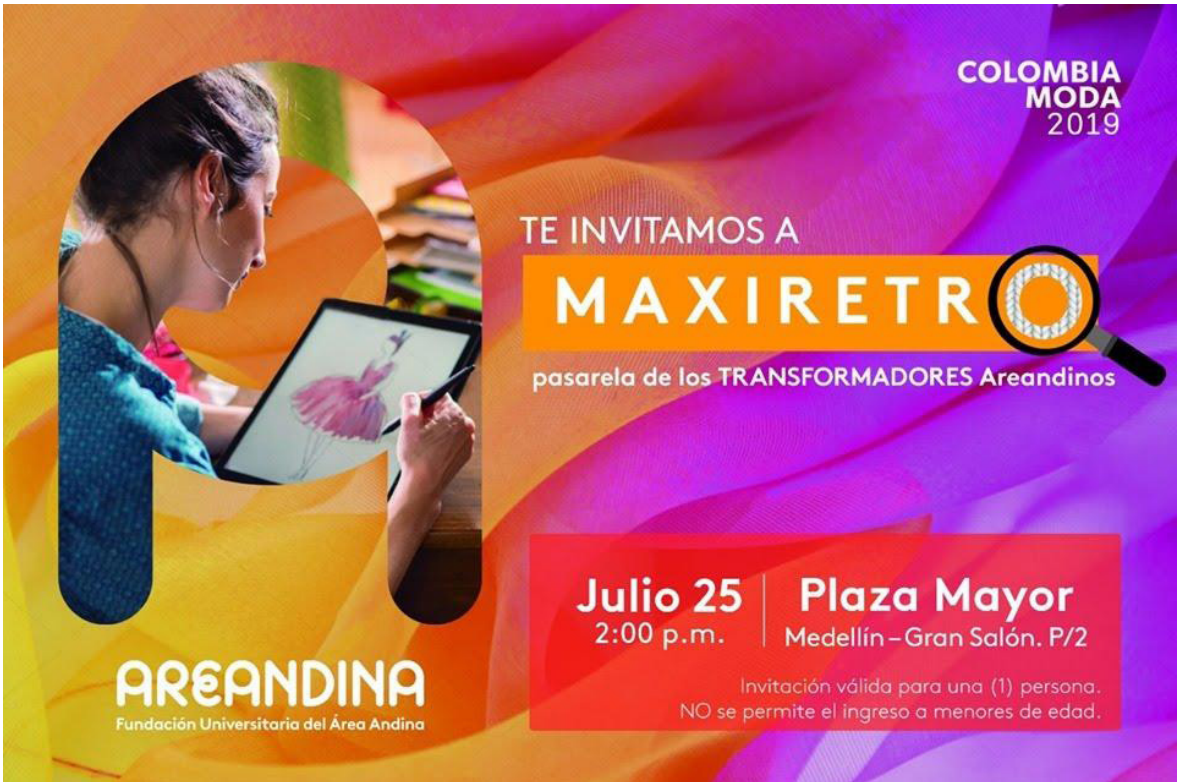

A continuación, imágenes del evento con los atuendos y autores citados en este documento:

https://www.facebook.com/camaralucidafotos/photos la.10157525179549673/10157525181719673/?type=3\&theater\&ifg=1

https://it-it.facebook.com/areandina/videos/382439535750027/ 


\section{Referencias}

8 monstruos de películas de terror que en realidad reflejan los problemas mentales de nuestra sociedad. Genial Guru. (s. f.). https://genial.guru/inspiracion-psicologia/8-monstruos-de-peliculas-de-terror-que-en-realidad-reflejan-los-problemas-mentales-de-nuestra-sociedad-662760/

Albrecht, K. (26 de febrero de 2015). Los cinco miedos que todos los seres humanos comparten. El Confidencial. https://www.elconfidencial.com/alma-corazon-vida/2015-02-26/terrores-universales-los-cinco-grandes-miedos-que-todos-compartimos_718067/

Alforfones (2016). ¿Por qué nos dan miedo las películas de terror?. El secreto de Berlanga. https://www.elsecretodeberlanga.com/2016/11/08/porque-nos-dan-miedo-las-peliculas-de-terror/

Arteaga, T. (27 de 05 de 2013). Anjana PatchWork. https://anjanapatchwork.com/

Avello, I. (1 de 03 de 2017). El 'look' del jueves: un toque 'patchwork'. El Mundo.

Bendazzi, G. (2003). Cartoons. 110 años de cine de animación. Ocho y Medio.

Bisson, D. (2018). Desarrollo de diseño (Calzado). WGSN. https://www-wgsn-com. proxy.bidig.areandina.edu.co/content/board_viewer/\#/79366/page/1

Black, S. (2012). Knitting. Fashion, Industry. Sandy Black.

Cañete, L. (2013). El cine de terror: radiografía de un género centenario. Vavel. https:// www.vavel.com/es/masvavel/2013/11/27/cine/306097.html

Cobos, T. (Abril de 2001). http://www.razonypalabra.org.mx/N/N72Naria_72/32_Cobos_72.pdf

Collioud, L. (2016). Curiosidades sobre Re-Animator, la película de terror inspirada en H.P. Lovecraft. Vix. https://www.vix.com/es/btg/cine/60844/curiosidades-sobre-re-animator-la-pelicula-de-terror-inspirada-en-h-p-lovecraft

Cuellar, M. (s. f.). La figura del monstruo en el cine de horror. Scielo. http://www.scielo. org.co/pdf/recs/n2/n2a10.pdf

Caltagirone. Visit Sicily. (2019). http://www.visitsicily.info/en/caltagirone/

Caltagirone, la colorida capital de la cerámica. Slow Italy. (2014). http://slowitaly.yourguidetoitaly.com/2014/10/caltagirone-the-colorful-capital-of-ceramics/ 
Carballo, L. E. (2018). Pasos básicos de tango porteño. BestDay.com. https://www.bestday.com.ar/Editorial/Pasos-Basicos-de-Tango-Porteno/

Casey, C. (2018). Ropa de punto. WGSN. https://www-wgsn-com.proxy.bidig.areandina. edu.co/content/board_viewer/\#/80817/page/1

Colcienciencias. (2016). Tipología de proyectos calificados como de carácter científico, tecnológico e innovación, 16 - 44.

Conceptodefinición. (24 de 03 de 2015). http://conceptodefinicion.de/proyecto/

Diana, D. (2014). Barroco. Toda materia. https://www.todamateria.com/barroco/

Documento de líneas de investigación. Facultad de diseño, comunicación y bellas artes. Grupo de investigación proyecta http://digitk.areandina.edu.co:8080/repositorio/handle/123456789/588

Dürr, E., Erhard, L., Eucken, W., y Giersch, H. (1983). La economía social de mercado: un proyecto económico y político alternativo. Konrad Adenauer Stiftung.

El miedo es un deseo y todo deseo es un miedo. Libertimento (2015). http://libertimento.com.mx/main/el-miedo-es-un-deseo-y-todo-deseo-es-un-miedo/

El origen del miedo a los monstruos. Escuelapedia. (s. f.). http://www.escuelapedia. com/el-origen-del-miedo-a-los-monstruos/

El patchwork está de moda: tendencias de tejidos 2015-2016. El Blog de Ribes \& Casals. (2 de 09 de 2015).

Etimologías de Chile. (2001). http://etimologias.dechile.net/?corchete

Fernandez, P. (S. f.). 5 películas de terror inspiradas en H.P. Lovecraft para verdaderos fanáticos del miedo. Vix. https://www.vix.com/es/btg/cine/8327/5-peliculas-de-terror-inspiradas-en-hp-lovecraft-para-verdaderos-fanaticos-del-genero

Gallart, V. (2014). Irresistibles: 100 años de it girls en la moda. Penguin Random House.

Gallo, G. (2 de agosto del 2011). Youtube. https://www.youtube.com/watch?v=ulzMmX2EWUE

Gill-Man: La criatura de la Laguna Negra. Wiki: Villanos del cine de terror. (s. f.). https:// villanos-del-cine-de-terror.fandom.com/es/wiki/Gill-man

Hernández, L. (2018). 18 películas Serie B que prestigian el bajo presupuesto. Cine Oculto.https://cineoculto.com/2018/11/18-peliculas-serie-b-que-prestigian-el-bajo-presupuesto/ 
Iglesias, I. (s.f.). Westwing. https://www.westwing.es/revista/estilo-de- vida/normas-estilo-coco-chanel/

INEXMODA. https://colombiamoda.inexmoda.org.co/es/

Killstar (2010). https://us.killstar.com/

Kosloski, P. (2017). Aleteia. https://es.aleteia.org/2017/07/23/este-es-el-porque-lasiglesias-tienen-vitrales/

Las 5 mejores películas en relatos de Edgar Allan Poe. Las cosas que nos hacen felices (2018). https://www.lascosasquenoshacenfelices.com/las-5-mejores-peliculas-basadas-en-relatos-de-edgar-allan-poe/

Lovecraft, H.P. (s. f.). El horror en la literatura. El terror. Algar Editorial. https://www. algareditorial.com/tl_files/pdfs/fragmentos/Escalofrios_FR.pdf

Macrotendencia secuencia creativa. WGSN (2019).

Martínez, A. (2016). El Mensaje Está en el Tejido. Futura Textos S.A. de C.V.

Matos, A. (2016). Te presentamos Creepshow, la comedia de horror de Stephen King y George A. Romero. Vix. https://www.vix.com/es/cine/169409/te-presentamoscreepshow-la-comedia-de-horror-de-stephen-king-y-george-a-romero

Maupassant, G. (1882). El miedo. Ciudad Seva. https://ciudadseva.com/texto/el-miedo/

Mini-Piplup75. (s.f.). 3D Juegos. Recuperado de https://www.3djuegos.com/foros/ tema/488612/0/la-historia-del-anime-detallada/

Moda Kawaii: ¿En Qué Consiste esta moda que arrasa en Japón? Sugoihunter.com. (21 de Septiembre de 2016). https://www.sugoihunter.com/moda-kawaii-consiste/

Montoya, I. (s. f.). De maldiciones y fluidos. El Colombiano. https://www.elcolombiano. com/blogs/cinefagos/tag/cine-de-serie-b

Montoya, L. (12 de Febrero de 2019). Historia del Anime. Historia-biografia.com. https://historia-biografia.com/historia-del-anime/

Morillo, M. (15 de 03 de 2006). ¿Qué es el patchwork? Deart Tee. http://www.deartee. com/blog/que-es-el-patchwork.html

Moscone. R. (2012). El miedo y su metamorfosis. Psicoanálisis XXIV. https://dialnet.unirioja.es/descarga/articulo/4243775.pdf

Nariño, G. (2016). Recuerado de https://xn--nario-rta.gov.co/turismo/phone/santuario-de-las-lajas.html 
Nieto, J. (s. f.). El miedo en la sociedad actual. Universidad de Murcia. https://webs. um.es/jalozate/lozanoteruel/ColaboracionesAmigas/Presentaciones/Elmiedoenlasociedadactual.pdf

Organización Delas Naciones Unidas para la Educación, la Ciencia y la Cultura (2009 https://ich.unesco.org/es/RL/el-tango-00258

Padilla, I. (2013). El legado de los monstruos. Tratado sobre el miedo y lo terrible. Taurus Pensamiento. https://books.google.com.co/books?id=7bEvAgAAQBAJ\&pg=P$T 7 \& \mid p g=P T 7 \& d q=$ porque+le+tememos $+a+$ los + monstruos\&source=bl\&ots $=5 \mathrm{~L}-$ qRMFh78E\&sig=ACfU3U2Ds9rtXKb9e6NPJsUIWIKORVcjeQ\&hl=es-419\&sa=X\&ved=2ahUKEwim6ovij5bhAhWDylkKHTv4Dho4FBDoATADegQICRAB\#v=onepage\&q=porque\%20le\%20tememos\%20a\%20los\%20monstruos\&f=false

Parra, J. (2017). Todos sus problemas durante el rodaje y otras curiosidades de "Posesión Infernal". E-Cartelera. https://www.ecartelera.com/noticias/44019/curiosidades-posesion-infernal/diez/

Patiño, M. (2018). RedBus. http://blog.redbus.co/turismo-y-aventura/igleisa-santuario-de-las-lajas/

Perier, M. (s.f.). VOGUE.FR. https://www.vogue.fr

Profe en historia. (2019). Barroco: arte, características y significado. https://profeenhistoria.com/barroco/

Plasencia, P. (2015). Las casquerías del cine de terror en los años 80. El Mundo. https:// www.elmundo.es/cultura/2015/09/01/55e4a397268e3e5e6e8b45ab.html

Psicologia y Mente. (s.f.). Poemas del romanticismo https://psicologiaymente.com/cultura/poemas-del-romanticismo

Re-Animator: 7 curiosidades de la película en su 30 aniversario. El solitario de Providence. (2015). http://www.elsolitariodeprovidence.com/2015/diez/re-animator-7-curiosidades-de-la.html

Ribadeneira, A. (2018). El monstruo es un espejo de la condición humana. El Comercio. https://www.elcomercio.com/app_public.php/tendencias/monstruos-cine-culturapop-laformadelagua-planetaeideas.html

Santino (2006). John Galliano para Dior. Santino. http://santino.blogspot.com/2006/01/ john-galliano-para-dior-2006.html 
Sephora. (19 de Marzo de 2011). Be Kawaii. https://kathygiraldo.wordpress. com/2011/03/19/historia-del-kawaii/

Shifres, F., Pereira, A., Herraera, R. y Bordoni, M. (2012). Estilo de ejecución musical y de danza en el tango: atributos, Competencia y experiencia dinámica. Cuadernos de música, artes visuales y artes escénicas. 7(2) 83-108.

Shoji.com, T. (2019). tadashishoji.com. Recuperado de https://www.tadashishoji.com/ about

Simons, R. (2017). American Horror Story en la mente de Raf Simons para Calvin Klein. WAG. https://www.wag1 mag.com/raf-simons-calvin-klein-2018/

Silveira, K. (s. f.). Cautivadoras y sensuales mujeres de la historia mundial. Vix. https://www.vix.com/es/btg/curiosidades/8114/cautivadoras-y-sensuales-mujeres-de-la-historia-mundial

Tapía, B. (2017). Nariño. https://xn--nario rta.gov.co/inicio/files/Publicaciones/LAS_LAJAS_UN_DESTINO_EMERGENTE.pdf

Team, T. (2018). Desarrollo de diseño. WGSN. https://www-wgsn-com.proxy.bidig. areandina.edu.co/content/board_viewer/\#/80690/page/1

Team, T. (2018). Secuencua creativa. WGSN. https://www-wgsn-com.proxy.bidig.areandina.edu.co/content/board_viewer/\#/80574/page/1

Tejidos al Crochet. (2011). http://tejidosalcrochet.com/tipgratuitos.html

The Monster Squad. (22 de marzo de 2019) En Wikipedia. https://es.wikipedia.org/wiki/ The_Monster_Squad

Un repaso por la moda de los años 60. Revista Bezzia. (2017). https://www.bezzia.com/ repaso-la-moda-los-anos-60/

Vanderborgh. I. (11 de 09 de 2017). Los orígenes del patchwork. Amapola Patch. https://www.amapolapatch.com/single-post/2017/09/11/Los-Or\%C3\%ADgenes-del-Patchwork

Veneziani, M. (2007). La imagen de la moda. Nobuko.

Villamil, P. (s.f.). Kika Vargas, fervor por los volúmenes. Revista Fucsia. https://www.fucsia.co/edicion- impresa/articulo/kika-vargas-tendencia-volumenes/581

Vuelven los 70: la década "antifashion" de la moda". Revista Fucsia. (2018). https://www. fucsia.co/moda/inspiracion/articulo/tendencia-en-moda-anos-70/60517 


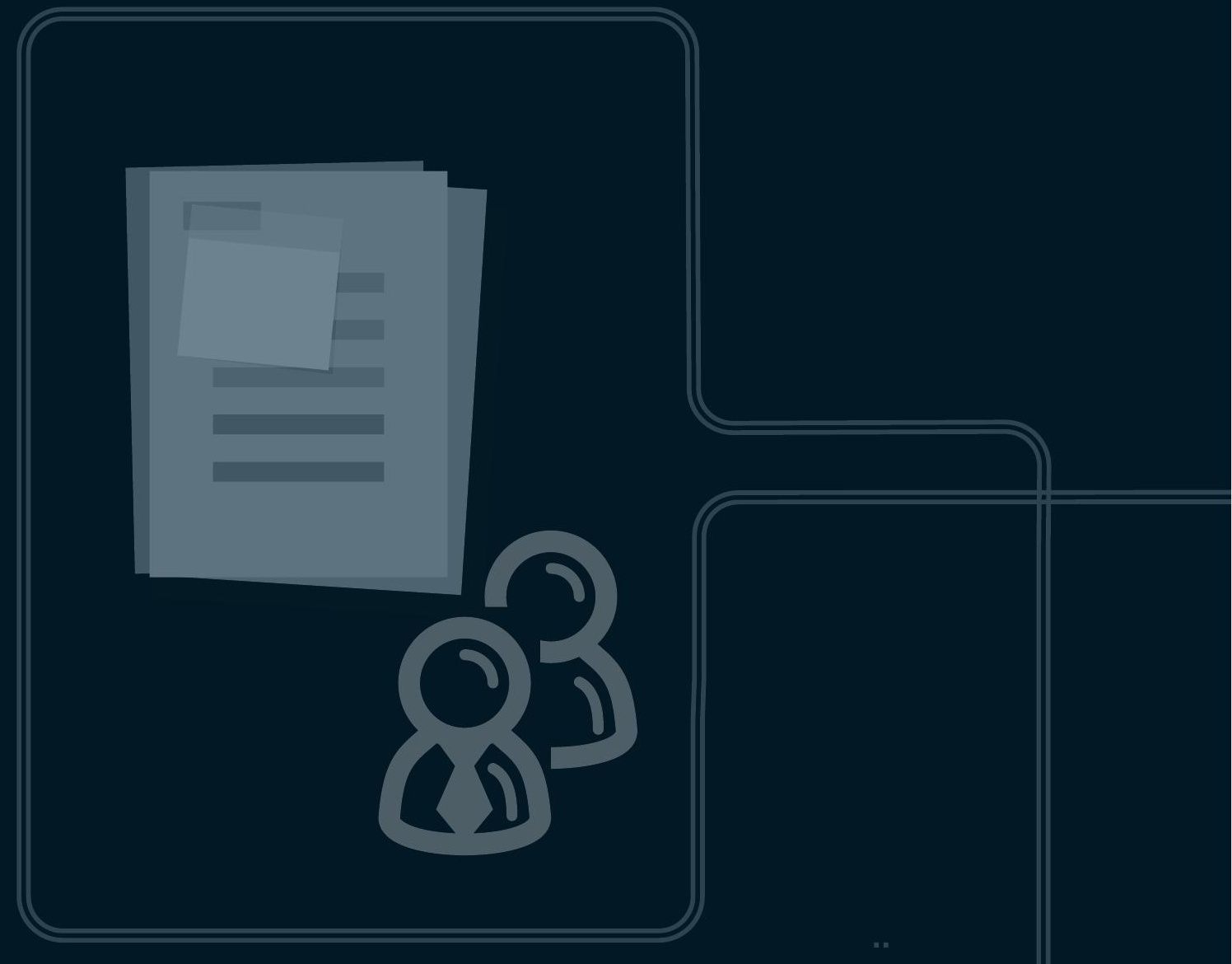

